\title{
EVOLUÇÃO E SUSTENTABILIDADE DO SETOR INDUSTRIAL MADEIREIRO NO ESTADO DE RONDÔNIA
}

\section{DANIELA DE PAULA ROCHA}

Bacharel em Ciências Econômicas

Orientador: Prof. Dr. CARLOS JOSÉ CAETANO BACHA

Dissertação apresentada à Escola Superior de Agricultura "Luiz de Queiroz", Universidade de São Paulo, para obtenção do título de Mestre em Ciências, Área de Concentração: Economia Aplicada. 


\section{Dados Internacionais de Catalogação na Publicação (CIP) DIVISÃo DE BIBLIOTECA E DOCUMENTAÇÃO - Campus "Luiz de Oueiroz"/USP}

\section{Rocha, Daniela de Paula}

Evolução e sustentabilidade do setor industrial madereiro no estado de Rondônia / Daniela de Paula Rocha. - . Piracicaba, 1999.

113 p. il.

Dissertação (mestrado) - - Escola Superior de Agricultura Luiz de Queiroz, 1999.

Bibliografia

1. Desenvolvimento sustentável 2. Exploraçāo florestal 3. Fiscalizaçāo 4. Indústria madeireira 5. Politica ambiental 6. Politica governamental I. Titulo 
Dedico

A Deus, por toda a obra

maravilhosa

que vem

realizando na minha

vida pessoal e profissional

Aos meus pais Rochilmer e Margarida

Aos meus irmãos Rochilmer,

Ana Lúcia e

Maria Lisieux

Aos meus sobrinhos Lucas, Gabriel e Bruna

Ao meu afilhado Antônio Felipe 


\section{AGRADECIMENTOS}

À minha família.

Aos meus pais Rochilmer e Margarida, sempre presentes nos momentos de alegria e de maiores dificuldades, me apoiando em todas as minhas decisões.

Aos meus padrinhos Maria Lúcia e Walter, que foram, em grande parte, responsáveis pela minha educação e por mais esta etapa vencida.

Ao Fábio por sua compreensão e companheirismo.

Ao meu orientador professor Dr. Carlos José Caetano Bacha, pelas sugestões, apoio, compreensão e paciência, durante todo o período de elaboração deste trabalho.

Ao professor Dr. Manuel Cabral, cujas contribuições no seminário, na qualificação e na mini banca foram de grande valia para o aprimoramento desta dissertação.

À CAPES, pelo auxílio e incentivo através da concessão da bolsa para o curso de mestrado.

Aos colegas da Fundação Getúlio Vargas, por todo o apoio concedido.

À Doutora Ignez e ao Doutor Mauro, pelo estímulo e incentivo na consecução do meu objetivo.

À Débora, que me auxiliou na pesquisa de campo.

Aos Técnicos da FIERO, que sempre se mostraram disponíveis em me atender, com especial destaque para a pessoa de Willian Cury.

Aos Técnicos do PLANAFLORO, por suas contribuições, com especial destaque para a pessoa de Eraldo Matricardi. 
Aos funcionários do Departamento de Economia, Administração e Sociologia Rural.

Aos colegas de turma: Lilian, Margarete, Augusto, Maurício, Felipe e Marcelo.

À Stivilane, cuja amizade foi iniciada no curso e perdura no ambiente de trabalho.

À Irene, colega de trabalho, que com toda a sua experiência me aconselhou nos momentos de maiores dificuldades, enfatizando que o mais importante na vida é o investimento no capital humano.

Aos professores do Departamento de Economia, Administração e Sociologia Rural, com especial destaque aos que foram meus professores: Carlos Bacha, Paulo Cidade, José Caixeta, Ana Lúcia, Adriano, João Martinez, Joaquim Bento e Pedro Valetim.. 
Página

LISTA DE FIGURAS............................................................................... iv

LISTA DE TABELAS.............................................................................. v

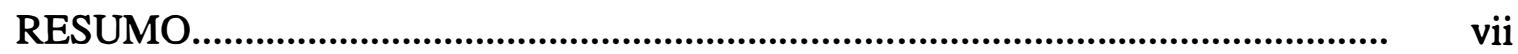

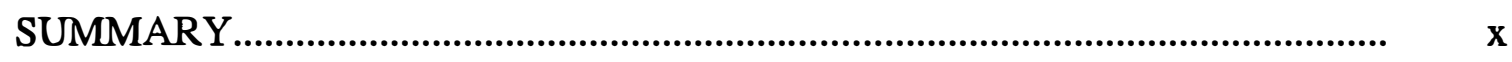

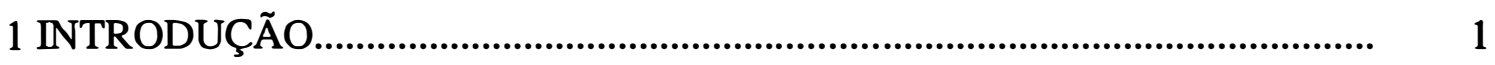

1.1 O Problema em estudo..................................................................................... 2

1.2 Revisão de Literatura. ………………………………................................... 5

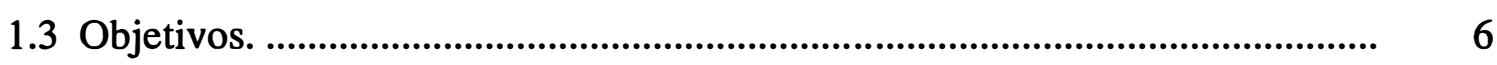

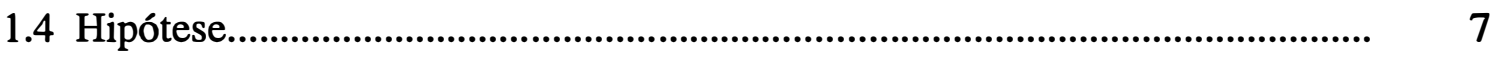

1.5 Importância do trabalho.................................................................................. 7

1.6 Organização do trabalho................................................................................. 8

2 CONSIDERAÇÕES TEÓRICAS SOBRE DESENVOLVIMENTO 10

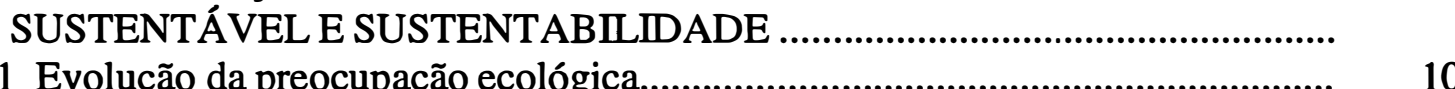

2.2 Correntes do pensamento econômico abordando a questão ambiental................ 13

2.3 O Conceito de desenvolvimento sustentável...................................................... 16

2.4 Sustentabilidade e desenvolvimento sustentável. ............................................... 18

2.5 Os Instrumentos de políticas propostos pela economia ecológica....................... 20

3 METODOLOGIA E FONTE DOS DADOS..................................................... 25

4 POLÍTICAS PÚBLICAS E OCUPAÇÃO DO ESTADO DE RONDÔNIA....... 31

4.1 A Amazônia e o atual Estado de Rondônia ........................................................ 32

4.2 Processo de migração e seu impacto sobre as florestas nativas........................... 34

4.3 POLONOROESTE.................................................................................. 36

4.4 Programa de zoneamento econômico-ecológico para a Amazônia Legal......... 39

4.5 Plano Agropecuário e Florestal de Rondônia (PLANAFLORO) ....................... 40

4.6 ICMS ecológico em Rondônia............................................................................ 45

5 EVOLUÇÃO DO SETOR INDUSTRIAL MADEIREIRO EM RONDÔNIA.... 49

5.1 Evolução do setor industrial madeireiro na Amazônia Legal.............................. 51

5.2 Relações entre exploração madeireira e desmatamento......................................... 55 
5.3 Fatores determinantes da localização das empresas.......................................... 58

5.4 Experiências e possibilidades da exploração madeireira sustentável em $\quad 60$ Rondônia..

6 ESTRATÉGIAS DE ABASTECIMENTO ADOTADAS PELAS EMPRESAS 64 INDUSTRIAIS PROCESSADORAS DA MADEIRA..

6.1 Caracterização da região em estudo................................................................... 65

6.1.1 O Processo de crescimento desigual da atividade industrial madeireira nos 67 pólos.

6.2 Aspectos vinculados à migração dos proprietários das empresas........................ 77

6.3 Escassez de espécies florestais........................................................................ 80

6.4 Eficácia dos órgãos ambientais em garantir a exploração florestal 83 sustentável

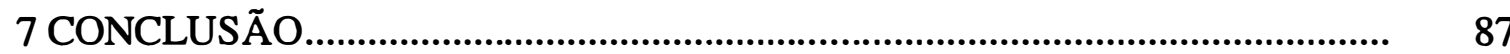

REFERÊNCIAS BIBLIOGRÁFICAS............................................................. 90

APÊNDICE A - QUESTIONÁRIO SOBRE O SETOR INDUSTRIAL 102 APÊNDICE B - EXPERIÊNCIAS DE EXPLORAÇÃO FLORESTAL SUSTENTÁVEL NO BRASIL 


\section{LISTA DE FIGURAS}

Página

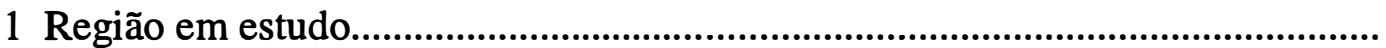

2 Produção média das empresas de processamento mecânico da madeira dos pólos 1 e 2 entre os anos de 1994 e 1997

3 Produtividade média das empresas de processamento mecânico da madeira dos pólos 1 e 2 entre os anos de 1994 e 1997

4 Evolução do número médio de empregados das empresas de processamento mecânico da madeira.

5 Evolução do número médio de empregados das empresas moveleiras 


\section{LISTA DE TABELAS}

Página

30

1 Número de empresas do setor industrial madeireiro de Rondônia distribuídas segundo seus municípios - 1997.

2 Tamanho da amostra pesquisada do setor industrial madeireiro do Estado de Rondônia

3 Evolução da população de Rondônia, entre 1950 e 1996, segundo seu domicílio.

4 Produção de madeiras na Região Norte ( $\mathrm{em} \mathrm{m}^{3}$ de toras)................................

6 Repartição de 25\% do ICMS entre os municípios de Rondônia de acordo com as Leis Complementares n $115 / 94$ e 147/96.

7 Índice de participação na cota do ICMS dos municípios de Rondônia beneficiados com o ICMS Ecológico

8 Número de empresas pertencentes ao setor industrial madeireiro de Rondônia em 1980, 1982, 1985, 1987, 1994 e 1997

9 Projetos de reflorestamento no Estado de Rondônia

69

10 Número de mudas distribuídas pelas Instituições de Fomento do reflorestamento no Estado de Rondônia.

11 Empresas de processamento mecânico de madeiras e moveleiras em alguns Municípios de Rondônia nos anos de 1985, 1994 e 1997.

12 Percentual de empresas do setor industrial madeireiro de Rondônia que desejam diversificar a produção.- situação em 1997

13 Percentual de empresas do setor industrial madeireiro de Rondônia que possuem plano futuro de ampliação da empresa - situação em 1997

14 Percentual de atendimento aos mercados das empresas do setor industrial madeireiro de Rondônia - situação em 1997.

15 Tamanho médio das empresas do setor industrial madeireiro - situação em 1997

16 Distribuição percentual das empresas do setor industrial madeireiro de 
Rondônia segundo o ano de instalação

17 Percentagem de empresas que tiveram mais de um proprietário, proprietários que tiveram mais de uma empresa e empresas co-ligadas.- setor industrial madeireiro de Rondônia, situação em 1997

18 Número médio de espécies florestais utilizadas pelas empresas do setor industrial madeireiro do Estado de Rondônia.

19 Número de empresas de processamento mecânico de madeira em Rondônia que usavam e as que deixaram de utilizar as espécies florestais mogno e cerejeira - situação em 1997

20 Percentagem de empresas do setor industrial madeireiro de Rondônia que foram fiscalizadas e orientadas - situação em 1997

21 Percentagem de empresas do setor industrial madeireiro de Rondônia que tem plano de manejo enviado ao IBAMA.- situação em 1997 
EVOLUÇÃO E SUTENTABILIDADE DO SETOR INDUSTRIAL MADEIREIRO NO ESTADO DE RONDÔNIA

Autora: DANIELA DE PAULA ROCHA Orientador: Prof. Dr. CARLOS JOSÉ CAETANO BACHA

\section{RESUMO}

A presente dissertação analisa a evolução do setor industrial madeireiro do Estado de Rondônia, procurando ater-se aos aspectos de sustentabilidade da exploração florestal e o desempenho das indústrias que o compõem. O setor industrial em questão é composto pelas empresas de processamento mecânico da madeira e pelas moveleiras.

Para uma maior compreensão das questões de sustentabilidade do respectivo setor, realiza-se a discussão teórica a respeito dos conceitos de desenvolvimento sustentável e sustentabilidade, descrevendo, inclusive, as principais correntes do pensamento econômico que abordam as questões ambientais. Optou-se, 
como forma de subsidiar a análise do setor industrial madeireiro de Rondônia, pela utilização da argumentação da economia ecológica.

Procura-se, por meio das idéias da economia ecológica, em um primeiro momento, discutir, cronologicamente, as políticas públicas referentes à ocupação e dinamização econômica de Rondônia, enfatizando como a preocupação com o desenvolvimento sustentável e a sustentabilidade foram, ou não, consideradas nestas políticas. Em um segundo momento, realiza-se a discussão da evolução, característica e sustentabilidade do setor industrial madeireiro da Amazônia Legal como um todo e de Rondônia, em particular. Em um terceiro momento, avalia-se, através de pesquisa de campo, as estratégias e desempenhos das empresas segundo o seu tipo e a região onde se localiza dentro de Rondônia.

Para efeito da pesquisa de campo, aplicaram-se questionários às empresas situadas em sete municípios, que apresentam a maior concentração delas. Os municípios são agrupados no pólo 1 (Vilhena, Pimenta Bueno, Rolim de Moura e Cacoal) e pólo 2 (Ji-Paraná, Ariquemes e Porto Velho). Essa divisão justifica-se pelo fato de a expansão da indústria de base florestal ter ocorrido mais intensamente no passado (caso do pólo 1) ou mais recentemente (pólo 2).

O Estado de Rondônia, assim como todos os demais inseridos na Amazônia Legal, sofreu incremento populacional e desenvolveu determinadas atividades, como a madeireira, que são, até o presente momento, de grande relevância para a economia regional. Estes fenômenos decorreram das políticas públicas voltadas à região que, num primeiro momento, preocuparam-se em incentivar a atividade produtiva e gerar fluxos migratórios oriundos de áreas onde havia conflitos pela posse da terra. A partir do final da década de 80 , as políticas públicas, principalmente as estaduais, passaram a incorporar explicitamente em seus objetivos as preocupações com a conservação e preservação ambiental, embora poucos resultados tenham sido obtidos.

O término da construção da BR-364, no final de 1960, e a sua posterior pavimentação, na década de 1980, aliados a abundância de recursos florestais, tornaram 
o setor industrial madeireiro a principal atividade industrial do estado, que, nos últimos anos, passa por sérios problemas.

Uma das principais dificuldades é a escassez relativa de madeira, especialmente as de maior valor comercial. Essa escassez é causada pela falta de preocupação com as questões de sustentabilidade por parte dos empresários do setor e pela pouca atenção dada pelas políticas públicas às questões ambientais no passado.

Constata-se, na pesquisa de campo, que os empresários do setor industrial madeireiro preferem alternativas de curto prazo para solucionarem a escassez relativa de madeira (como a transferência das empresas para outras regiões ou a troca da espécie florestal utilizada). A política de fiscalização dos órgãos florestais não tem levado à mudança neste comportamento. 
THE EVOLUTION AND SUSTAINABILITY OF THE WOOD INDUSTRIAL SECTOR IN THE STATE OF RONDÔNIA

\author{
Author: DANIELA DE PAULA ROCHA
}

Advisor: Prof. Dr. CARLOS JOSÉ CAETANO BACHA

\title{
SUMMARY
}

This dissertation analyses the evolution of the wood industrial sector in the state of Rondônia, focusing on the sustainability of forest exploitation and the industrial performance. The industrial sector here comprises firms processing mechanically wood and furniture manufacturers.

In the literature review chapter, there is a theoretical discussion about sustainable development and sustainability concepts, and the main economic thoughts about environmental issues. For the purpose of this study, the analysis of the wood industrial sector is based on the concepts of ecological economics. 
At the first stage, there is a discussion, in chronological order, about the public policies concerning the occupation and economic dynamics of Rondônia, emphasizing whether or not they have considered sustainable development and sustainability questions. The next step is the discussion of evolution, characteristics and sustainability of the wood industrial sector in the entire Amazon Region, and specially in Rondônia. Finally, using information from a field survey, strategies and performances of enterprises are evaluated according to their type and regional location.

The field survey was conducted applying questionnaires to enterprises located in seven municipalities (counties), where most of the wood industrial sector is concentrated. These counties were arranged in two zones: zone 1 is constituted by Vilhena, Pimenta Bueno, Rolim de Moura, and Cacoal; and zone 2 includes Ji-Paraná, Ariquemes, and Porto Velho. This division is based to the period the wood industry expanded more intensely: in the past (case of zone 1), or more recently (case of zone 2).

Similar to other states in the Amazon Region, Rondônia experienced a great population growth and developed specific industrial activities such as the wood industry. These activities have a great importance on the regional economy. The economic and population growth are a result of public policies targeted to stimulate regional production, which created migratory flows from regions with land disputes. At end of the 80 s, public policies, mainly state policies, included in their agendas environmental conservation and preservation issues. However, few positive results have been obtained.

The construction of BR-364's roadway at the end of 1960, and its subsequent paving in the 80's, together with the abundance of forest turned the wood industrial sector the main industrial activity in Rondônia. However, in recent years, this sector is facing serious problems.

One of the main difficulties is the relative scarcity of wood, mainly trees of greater commercial value. That scarcity was caused by entrepreneurs lack of awareness with sustainability issues, and failure of the public policies address the environmental issues in the past. 
The field survey revealed that entrepreneurs of the wood industrial sector used short term alternatives to solve the problem of wood scarcity, such as, relocating their enterprises or changing the tree' species exploited. Supervisory policies implemented by public institutions have not resulted in a behavioral change. 


\section{INTRODUÇÃO}

Este trabalho analisa a evolução do setor industrial madeireiro do Estado de Rondônia, enfocando os aspectos de sustentabilidade da exploração florestal e o desempenho das indústrias que compõem esse setor.

Para o propósito desta dissertação, o setor industrial madeireiro é composto pelas indústrias que realizam a transformação mecânica da madeira, que, no caso de Rondônia, são basicamente as serrarias, as fábricas de laminados e compensados, e as fábricas de móveis.

Alguns exemplos de atividades realizadas por estas indústrias são: desdobramento da madeira; fabricação de estruturas de madeira e artigos de carpintaria; fabricação de chapas e placas de madeira aglomerada ou prensada, compensada, revestida ou não com material plástico (inclusive artefatos); fabricação de artigos diversos de madeira'; e, fabricação de móveis de diversos tipos.

\footnotetext{
' Como a fabricação de cabos para ferramentas e utensílios, fabricação de artigos de madeira torneada (exclusive para uso doméstico), fabricação de saltos e solados de madeira, fabricação de formas e modelos de madeira (exclusive de madeira arqueada), fabricação de molduras e execução de obras de talha (exclusive artigos do mobiliário) e a fabricação de artigos de madeira para usos doméstico, industrial e comercial.
} 


\subsection{O Problema em estudo}

A Amazônia Legal é, atualmente, a principal região produtora de madeira no Brasil. De acordo com Kitamura (1994, p.95), a produção de madeira dessa região passou de, aproximadamente, 10 milhões de $\mathrm{m}^{3}$ em 1973 para mais de 50 milhões de $\mathrm{m}^{3}$ em 1989. Neste último ano, a produção de madeira, nesta região, representava aproximadamente $76 \%$ da produção nacional.

O estado que apresenta a maior contribuição na produção de madeira é o Pará, com mais de $90 \%$ da produção regional, seguido por Rondônia $(4,5 \%)$ e Mato Grosso (3,3\%). Observa-se que estes últimos apresentam uma participação baixa, porém, o quadro se modifica quando se verifica a importância deste tipo de atividade para cada um dos estados pertencentes à Amazônia Legal. Por exemplo, nos estados de Rondônia e Roraima, em 1989, os produtos madeireiros correspondiam a mais de $60 \%$ de seus produtos industriais.

O trabalho da UFRRJ/IBDF (1988) confirma a importância do setor industrial madeireiro de Rondônia para a economia estadual. No ano de 1980, a produção industrial desse Estado foi da ordem de US\$ 73 milhões (considerando 7 setores), sendo que $61 \%$ deste valor procedia do setor industrial madeireiro. De acordo com o estudo acima citado, este setor é o que mais rápido cresceu na Amazônia (passando de 4,0\% do valor da produção industrial regional em 1975 para 9,8\% em 1980, com uma taxa média de crescimento da produção de $29 \%$ ao ano). 
No Estado de Rondônia - em decorrência, especialmente, dos incentivos fiscais concedidos ao setor industrial madeireiro, da expansão da malha rodoviária e da existência de recursos florestais - verificou-se um incremento no número de empresas pertencentes ao setor industrial madeireiro. Esse conjunto de empresas é o que apresenta maior participação no total de estabelecimentos industriais do estado. Sua participação, em 1987, foi da ordem de 51,55\%; sendo que, no final da década de 80 , esse setor industrial correspondia a 35\% da arrecadação geral de impostos em Rondônia (FIERO, 1995; e, SEPLAN, 1990).

Apesar da maior participação do setor industrial madeireiro no total de estabelecimentos industriais em Rondônia, aquele setor está passando por um processo de transformação ao longo dos últimos anos. $\mathrm{O}$ número de empresas que faz o desdobro mecânico da madeira (serrarias) e de fabricação de estruturas de madeira e artigos de carpintaria diminuiu entre 1987 e 1994, enquanto ocorreu aumento no número de empresas produtoras de chapas de madeiras, produtoras de artigos diversos de madeira $\mathrm{e}$ de móveis (FIERO, 1995; e, SEPLAN - RO, 1990).

Além dessas transformações, o setor industrial madeireiro em Rondônia tem enfrentado algumas dificuldades. Uma delas é a exaustão dos recursos florestais. A exploração seletiva e predatória das espécies arbóreas tem causado a escassez de madeira, forçando as empresas a desativar suas plantas ou mudar para outras cidades.

Mesmo com a aquisição de poucas espécies, verifica-se que diversos danos são causados às florestas tropicais em decorrência da abertura de estradas de exploração, da derrubada e da extração de árvores. O estudo realizado por Veríssimo et al. (1996b), nos arredores de Paragominas (PA), com condições edafo-climáticas próximas às de Rondônia, constatou que se em média 6,4 árvores são extraídas por hectare, aproximadamente 150 árvores/ha (com diâmetro a altura do peito maior do que $10 \mathrm{~cm}$ ) sofrem danificações. 
O que se observa na Amazônia Legal como um todo nos dias de hoje é uma atividade de extração e processamento industrial de madeira que possui uma baixa eficiência, causada por: baixo aproveitamento da capacidade industrial instalada; equipamentos ultrapassados; elevado desperdício de matéria-prima; e, forma de extração florestal predatória e extremamente seletiva.

Atualmente, percebe-se uma maior pressão de órgãos oficiais, especialmente do IBAMA, para que a exploração dos recursos florestais realize-se de forma sustentável, através do manejo florestal sustentável, ou que sejam realizados reflorestamentos. Porém, o número de empresas pertencentes ao setor industrial madeireiro que pratica uma dessas duas opções ainda é pequeno. Deve-se salientar que ainda há vários gargalos na forma de ação do IBAMA.

Alguns fatores - como pressões internacionais contra a ocupação desordenada da Amazônia, os atuais modelos adotados para a exploração dos recursos naturais e as modificações verificadas na legislação ambiental, que obriga a reposição florestal ou a prática de manejo por parte da firma que consome grande volume de matéria-prima florestal - estão influenciando de forma restritiva o setor industrial madeireiro em Rondônia.

Outro ponto que deve ser ressaltado é que na década passada o desmatamento no Estado de Rondônia foi bastante intenso. De acordo com algumas estimativas, realizadas na década de 80 , se o desmatamento continuasse em tal ordem, o estado estaria desprovido de suas florestas nativas entre os anos de 1993 e 1994, fato que ainda não ocorreu devido a uma desaceleração no ritmo de desmatamento, mas que não deixa de ser alarmante. A área desmatada no Estado de Rondônia no período 1994/1995 (segundo semestre de 1994 e primeiro semestre de 1995) foi de aproximadamente 4.730 $\mathrm{km}^{2}$. Entre 1995/1996, observou-se uma redução para cerca de $2.432 \mathrm{~km}^{2}$ (INPE, 1998).

Os danos causados ao meio ambiente, principalmente pelo grande fluxo 
migratório observado em direção ao Estado de Rondônia, foram fatores decisivos para a criação do Plano Agropecuário e Florestal de Rondônia (PLANAFLORO), na segunda metade da década de 80. Este Plano tem como principal objetivo a execução de ações que proporcionem o aproveitamento racional dos recursos naturais, com o intuito de favorecer o desenvolvimento sustentável de Rondônia.

O contrato de empréstimo para o Plano foi assinado em 19 de setembro de 1992, entre o Banco Internacional para Reconstrução e Desenvolvimento (BIRD) e a República Federativa do Brasil. A execução do projeto fica a cargo do Estado de Rondônia.

Não obstante as transformações e dificuldades enfrentadas pelo setor industrial madeireiro e pela atividade madeireira em Rondônia, aquele setor ainda tem grande importância econômica e social para o estado, principalmente quando se observa a quantidade de recursos financeiros que mobiliza e a quantidade de empregos diretos e indiretos que gera em seu âmbito, cerca de 15.000 no que se refere ao emprego direto (FIERO, 1997).

\subsection{Revisão de Literatura.}

Na revisão de literatura realizada, constatou-se que há vários trabalhos que já descreveram o processo de desmatamento na Amazônia Legal e em Rondônia, em especial, discutindo suas causas. Entre esses trabalhos, destacam-se: Diegues (1993); Fearnside (1984); Fearnside (1992); Feamside (1982); Fearnside (1991); Fearnside \& Salati (1985); ITERON (1996); Kitamura (1994); Leopoldo \& Salati (1987); Lisboa (1986); Lisboa (1989); Lisboa et al (1991); Lisboa (1990); Mahar (1990); Matricardi (1996); SECRETARIA ESPECIAL DO MEIO AMBIENTE (1986); SEDAM (1996); 
SEDAM (1997); Uhl \& Buschbacher (1991); e, Uhl \& Vieira (1991).

Também existem trabalhos que apresentam panoramas do setor industrial madeireiro em Rondônia, como: Browder (1989); Browder (1986); FIERO (1995); FIERO (1997); IBAMA/FUNATURA (1996); Lisboa et al (1991), Lisboa (1986); Lisboa (1990); Matricardi \& Abdala (1994); Terezo (1990); UFRRJ/IBDF (1983); e, UFRRJ/IBDF (1988).

Contudo, falta um trabalho que analise a evolução desse setor industrial madeireiro ao longo do tempo e aborde a sua sustentabilidade diante do processo atual de desmatamento da Amazônia Legal e de Rondônia, em especial.

\subsection{Objetivos}

Por isso, o objetivo geral deste trabalho é analisar a evolução do setor industrial madeireiro do Estado de Rondônia, observando os aspectos de sustentabilidade da exploração florestal e o desempenho das indústrias que compõem esse setor.

Os objetivos específicos desta dissertação são:

- discutir os conceitos de desenvolvimento sustentável e sustentabilidade, e analisar como eles podem ser aplicados ao uso dos recursos florestais da Amazônia Legal (onde se situa o Estado de Rondônia);

- verificar como a questão da sustentabilidade do uso de recursos florestais foi tratada nos planos e políticas federais e estaduais de desenvolvimento de Rondônia. Em especial, procura-se analisar como esses programas impactaram o setor industrial madeireiro. 
- analisar os fatores que influenciaram as mudanças ocorridas no setor industrial madeireiro do Estado de Rondônia a partir da década de 70;

- comparar as condutas, no que se refere ao abastecimento de madeira, e desempenhos das empresas industriais de base florestal, segundo o seu ramo de atividade, em duas regiões distintas do Estado de Rondônia: uma de ocupação mais tardia e outra de ocupação mais recente. Procura-se observar como essas empresas se preocupam com a sustentabilidade do uso dos recursos florestais.

\subsection{Hipótese}

A hipótese que norteia este trabalho é que, mesmo com a relativa escassez de diversas espécies florestais no Estado de Rondônia, os proprietários de empresas pertencentes ao setor industrial madeireiro deste Estado ainda não se conscientizaram plenamente da importância da utilização dos recursos florestais de forma sustentável, preferindo solucionar tal problema por meio de medidas menos custosas - como a migração para outras regiões, em vez de uma diminuição do lucro no curto-prazo. A diminuição do lucro no curto prazo, neste caso, refere-se ao caso de a empresa funcionar de forma sustentável, adotando o manejo florestal ou realizando o reflorestamento.

\subsection{Importância do trabalho}

O trabalho em questão é de grande relevância no que diz respeito ao fornecimento de subsidios para um melhor entendimento da evolução e da situação atual do setor industrial madeireiro do Estado de Rondônia. Com isto, buscam-se alternativas 
para que o setor se torne sustentável no longo prazo.

O que se verifica, atualmente, é que se a exploração dos recursos florestais e, conseqüentemente, o setor industrial madeireiro continuarem a funcionar nos moldes tradicionais, ou seja, de forma não sustentável, eles desaparecerão, em grande parte, no futuro próximo. A sobrevivência deste tipo de setor dependerá, em primeira instância, de um funcionamento que tenha como base o desenvolvimento sustentável.

Neste trabalho, por meio das idéias de sustentabilidade, segundo a economia ecológica, verificar-se-á a conduta no que se refere ao abastecimento da madeira e o desempenho das empresas que compõem o setor industrial madeireiro do Estado de Rondônia. Para tanto, foi realizada uma pesquisa de campo, através da aplicação de questionários.

\subsection{Organização do trabalho}

Esta dissertação é constituída por sete capítulos, incluindo esta introdução. O segundo capítulo traz alguns comentários teóricos sobre a questão de desenvolvimento sustentável e sustentabilidade e sobre sua aplicabilidade à Amazônia Legal (onde se insere Rondônia).

O terceiro capítulo aborda a metodologia e as fontes dos dados utilizados no trabalho. Em especial, neste capítulo são expostos os aspectos metodológicos da pesquisa de campo realizada para avaliar as condutas e estratégias das empresas quanto ao abastecimento de madeira e obter alguns indicadores de seus desempenhos.

No quarto capítulo são tratadas as Políticas Públicas e o processo de ocupação do Estado de Rondônia, observando a preocupação, ou não, com o 
desenvolvimento sustentável e a sustentabilidade.

O quinto capítulo analisa a evolução do setor industrial madeireiro em Rondônia, enfocando aspectos como desmatamento e sustentabilidade da exploração madeireira.

O sexto capítulo, de caráter complementar ao anterior, verifica as estratégias de abastecimento de madeira adotadas pelas empresas processadoras da madeira, bem como o desempenho dessas empresas, e pelas empresas moveleiras em duas regiões (pólos 1 e 2) do estado. Por meio de pesquisa de campo realizada, procurase verificar diferenças existentes dentro do setor industrial madeireiro e segundo a sua localização. E, por fim, o sétimo capítulo traz as principais conclusões e sugestões desta dissertação. 


\section{CONSIDERAÇÕES TEÓRICAS SOBRE DESENVOLVIMENTO SUSTENTÁVEL E SUSTENTABILIDADE}

Este capítulo aborda, teoricamente, os conceitos de desenvolvimento sustentável e sustentabilidade, com o intuito de essas idéias serem aplicadas, mais especificamente, na análise das políticas públicas do Estado de Rondônia e de seu setor industrial madeireiro.

O presente capítulo é composto de cinco itens. Inicialmente, faz-se um breve comentário sobre a evolução da preocupação ecológica (item 2.1). No item posterior (2.2), são descritas as principais correntes do pensamento econômico que abordam as questões ambientais e explicita a corrente a ser usada nessa dissertação. Em seguida, é tratado o conceito de desenvolvimento sustentável (item 2.3), para se analisar, no item 2.4, as relações existentes entre sustentabilidade e desenvolvimento sustentável. $\mathrm{O}$ item 2.5 expõe os principais instrumentos de política propostos pela Economia Ecológica.

\subsection{Evolução da preocupação ecológica}

Os estudos sobre ecologia vêm sendo realizados há mais de um século. Não obstante, a preocupação ecológica intensificou-se a partir do final da década de 40 . Em 1948, foi implantada a União Internacional para a Proteção da Natureza (UIPN), 
criada por um grupo de especialistas das Nações Unidas. Em 1949, foi realizada a Conferência Científica das Nações Unidas sobre Conservação e Utilização de Recursos, sendo este o primeiro grande acontecimento em nível do ambientalismo mundial (Leis \& D'amato, 1995, p. 80).

As preocupações ambientais surgiram em decorrência dos efeitos indesejáveis do crescimento econômico sobre a qualidade do meio ambiente. Dentre esses efeitos, os mais citados foram os seguintes: "a deterioração da qualidade do ar e da água, a acumulação de resíduos sólidos, os ruídos nas áreas urbanas e o mau uso da terra" (Kitamura, 1994, p. 11).

Durante as décadas de 50 e 60, os estudos sobre as questões ecológicas provinham da comunidade científica e dos chamados ambientalistas nãogovernamentais. Nesta época, os maiores destaques foram os trabalhos de Rachel Carlson, em 1962, com o título "Silent Spring" e os relatórios científicos do Clube de Roma, que tiveram início em 1968. Um desses relatórios - com o título “Os Limites do Crescimento" - chamava a atenção para o fato de que se o crescimento populacional e da produção do mundo continuassem no mesmo ritmo a longo prazo, eles iriam resultar em catástrofe no próximo século. A poluição da atmosfera decorrente da queima de combustíveis; a poluição das águas dos rios, lagos, mares e oceanos através de produtos químicos; e a degradação dos solos, via a erosão e a utilização de agrotóxicos, desencadeariam à humanidade uma intensa escassez de alimentos. Ressuscitava-se, com isto, a velha tese malthusiana da escassez de alimentos. A proposta para a não ocorrência de problemas de escassez de alimentos estava relacionada com uma política de crescimento zero. Esse modelo de análise, porém, foi severamente questionado pelos países do Terceiro Mundo. Para esses, tal política vincularia a riqueza aos países industrializados e eternizaria a pobreza nos países subdesenvolvidos (Kitamura, 1994; Leis \& D'amato, 1995, p.80; Costa, 1995b; e, Benchimol, 1992, p.163).

$\mathrm{Na}$ década de 70 , as maiores preocupações referentes às questões 
ambientais procediam dos partidos políticos. Esse período foi marcado pela Conferência de Estocolmo, realizada em 1972. As principais conclusões tiradas nessa conferência foram: a proteção do meio ambiente já era considerada um problema de grande importância que influenciava o bem-estar das populações e o desenvolvimento econômico do mundo; o crescimento natural das populações humanas gera problemas permanentes à preservação do meio ambiente; e, os grandes problemas que dizem respeito ao meio ambiente dos países industrializados relacionavam-se à poluição industrial e, em contrapartida, os problemas comuns dos países em desenvolvimento se referiam ao mau uso e esgotamento de recursos naturais (Leis \& Amato, 1995; Kitamura, 1994; e, Costa, 1995).

Durante esta mesma década de 70, verificou-se a expansão de agências estatais do meio ambiente e a implantação do Programa das Nações Unidas para o meio ambiente (UNEP), além da consolidação de partidos verdes.

Do exposto acima, constata-se que o destaque nos anos 50 ficou a cargo dos ambientalistas ligados ao meio científico, nos anos 60 às organizações nãogovernamentais e nos anos 70 aos atores políticos e estatais. Todos esses agentes tiveram seus apogeus na década de 80 .

Em 1983, foi criada a Comissão Brundtland, que publicou o relatório “Nosso Futuro Comum", em 1987. Verificou-se, então, a entrada em cena dos atores associados ao sistema econômico (empresas). Devido à possibilidade de escassez dos recursos naturais nesta década, algumas empresas se vincularam ao conceito de "desenvolvimento sustentável" e à idéia de um mercado verde, onde surgem preocupações com as questões ambientais (Leis \& D'amato, 1995). 


\subsection{Correntes do pensamento econômico abordando a questão ambiental}

A análise da relação economia, sociedade e ambiente é enfocada por diversas correntes do pensamento econômico, sendo que cinco delas se destacam em nível mundial (Sekiguchi \& Pires, 1995).

A primeira corrente é considerada como a que possui uma linha de pesquisa que mais se assemelha à da teoria econômica neoclássica tradicional. Teve bastante destaque nas décadas de 60 e 70, especialmente pelo uso de técnicas de análises de custos/benefícios e insumo/produto na avaliação e/ou contabilização de políticas ambientais hoje utilizadas e nas questões relacionadas às economias da poluição ou dos recursos naturais.

Por possuir um caráter aplicado, essa corrente tem como característica fundamental definir estimativas de "valores" com o intuito de medir perdas ou danos ambientais, salientando a incapacidade do mercado como único e exclusivo mecanismo de regulação social e econômica. O que se pretende nessa corrente é determinar o preço do dano. Ou seja, os consumidores estipulam um valor mínimo dos sócio-ecossistemas impactados por uma falha ou dano ambiental de um determinado local ou microrregião

A importância dessa corrente é que ela fornece subsídios às políticas ambientais, principalmente nos países industrializados, por meio da elaboração de uma contabilidade ambiental ou de qualidade de vida, incluindo não somente os indicadores econômicos tradicionais (como os usados dentro dos sistemas de Contas Nacionais), como também outros indicadores de sustentabilidade ou de mensuração da qualidade de vida dos países que decidem seguir esse novo modo de "medir seu desenvolvimento".

Essa primeira corrente tem algumas limitações. Entre elas, destacam-se: 
procura converter todos os valores passíveis de ser medidos em termos de valores monetários e desconsidera outros aspectos que não sejam os puramente econômicos.

A segunda corrente é a que trata das abordagens desenvolvimentistas da economia do meio ambiente. Elas concentram seus estudos em análises dos estilos ou modelos de desenvolvimento através da elaboração de propostas alternativas para os chamados países dependentes ou do Terceiro Mundo. Ou seja, as questões sócioambientais são tratadas por meio da teoria do desenvolvimento. As limitações dessa corrente dizem respeito à questão da execução concreta dos conceitos e das propostas elaboradas por autores que defendem esse tipo de abordagem. Apesar deste fato, não se descarta a importância dessa corrente na busca de abordagens que serão de grande utilidade na formulação de políticas econômicas mais sustentáveis.

Outra corrente é a da economia marxista e a natureza. A idéia de ambiente na análise marxista da natureza surge como o ambiente das relações de produção e trabalho. Nesse grupo não há um desenvolvimento da teoria econômica marxista do meio ambiente como existe, por exemplo, na economia ambiental neoclássica. Verifica-se apenas uma relação histórica entre sociedade e natureza pela ótica do trabalho. Por meio dessa relação - que é estabelecida pelo processo do trabalho e pelo desenvolvimento de forças produtivas aí envolvidas -, passa-se a compreender os diferentes problemas ambientais de regiões e países, que são gerados pelos agentes sociais produtores de mercadorias

No que se refere à valoração do meio ambiente, percebe-se que a noção de "trabalho socialmente necessário" apenas diz respeito a uma parcela dos recursos naturais, que é a do tempo gasto pela atividade econômica para retirar tal recurso do solo. Verifica-se que falta incluir na noção marxista o outro valor do recurso natural que não se refere ao trabalho humano, mas ao "trabalho" da natureza para produzi-lo, de um valor que existe em si mesmo, independentemente do trabalho humano. 
A quarta corrente é a Economia Política do Meio Ambiente, que por meio de uma série de autores e trabalhos busca incorporar em suas reflexões o lado político da ecologia, sendo considerada por alguns como Economia Política.

Essa corrente não está bem estruturada quando confrontada com as demais. De acordo com Sekiguchi \& Pires (1995), devem ser incluídos elementos que inter-relacionam as diversas abordagens de um modo mais adequado com a realidade verificada em países do terceiro mundo

Como quinta corrente tem-se a chamada economia ecológica, que se baseia em uma abordagem mais preventiva contra as catástrofes ambientais existentes, defendendo a conservação dos recursos naturais por meio de uma visão que, adequadamente, leve em consideração as necessidades potenciais das gerações futuras. De acordo com essa abordagem, o crescimento é limitado pela escassez dos recursos naturais, não podendo ser superado apenas por meio de progresso tecnológico. A economia ecológica é a corrente mais ampla e radical quando comparada com as outras no que diz respeito à proposta metodológica de análise, pois esta última envolve no mesmo arcabouço teórico a relação da economia com a ecologia, a física, a química e a biologia modernas. O seu objetivo é tentar conciliar os métodos quantitativos, como os elaborados dentro da economia ambiental, com uma idéia mais abrangente de ampliação das noções de sustentabilidade atualmente empregadas. Para obter tal resultado, essa corrente faz uso do conceito termodinâmico de entropia, sendo o trabalho de Nicholas Georgescu Roegen o pioneiro na aplicação desse conceito na análise econômica (May, 1995; Sekiguchi \& Pires, 1995).

Na presente dissertação utiliza-se a argumentação da economia ecológica pelo fato de sua metodologia de análise ser ampla e incluir no mesmo arcabouço teórico a relação da economia com outras ciências. Com isso, poder-se-á abordar os aspectos de sustentabilidade na evolução do setor industrial madeireiro de Rondônia. 
Além disso, a economia ecológica possui um instrumental de análise mais adequado a pesquisas preocupadas com a sustentabilidade no uso dos recursos naturais. Segundo May (1995, p.7):

"Em vez de começar a análise com a questão da eficiência alocativa colocada pelos economistas neoclássicos e, a partir daí, procurar internalizar os custos ambientais e distributivos, os economistas ecológicos invertem a ordem dessas preocupações. A capacidade de suporte da terra é considerada primordial para definir os limites do impacto das atividades humanas em uma escala julgada ecologicamente sustentável. Em segundo lugar, a permissão às atividades poluidoras e o acesso aos recursos deveriam ser distribuídos de forma eqüitativa. Somente em um terceiro momento, após haver tomado decisões relativas a uma escala ecologicamente sustentável e uma distribuição eticamente justa, estaremos nós em posição de permitir a realocação entre indivíduos através de mercados nos interesses da eficiência. Até o numerário através do qual as escolhas alternativas seriam avaliadas poderia sofrer alterações para remover os efeitos distorcidos dos mercados".

\subsection{O Conceito de desenvolvimento sustentável}

O conceito de desenvolvimento sustentável surgiu no início da década de 80 do presente século, quando a União Internacional para a Conservação da Natureza (UICN) elaborou o Documento Estratégias de Conservação Mundial, com o intuito de atingir o desenvolvimento sustentável por meio da conservação dos recursos vivos. Mas tal conceito só se tomou popular a partir do Relatório Brundtland (Nosso Futuro Comum, publicado em 1987), estando no centro do discurso ecológico oficial. Muita discussão, porém, surgiu a partir de então, não havendo, atualmente, consenso quanto ao seu significado.

O desenvolvimento sustentável, segundo o Relatório Brundtland, é o que atende às necessidades das pessoas sem comprometer a possibilidade de as gerações 
futuras atenderem às suas próprias necessidades (Leis \& D'amato, 1995; Stahel, 1995; Baroni, 1992, p. 15; e, Mendes, 1995). Esse tipo de desenvolvimento é baseado em um processo de mudança no qual a exploração de recursos, a direção dos investimentos, a orientação do desenvolvimento tecnológico e a mudança institucional estão todos em harmonia (Opschoor \& Straaten, 1993, p.203).

No Relatório "Nosso Futuro Comum" é enfatizado que os modelos predominantes de crescimento econômico são ecologicamente não viáveis, sendo necessária uma nova política econômica. A noção de desenvolvimento sustentável terá que ser adequadamente incorporada dentro da teoria econômica, com repercussões para, entre outras coisas: 1) o tratamento dos recursos naturais como fatores de produção, bem como determinantes de bem-estar, 2) avaliação teórica, e 3) avaliação das forças de mercado (Opschoor \& Straaten, 1993).

Nos últimos dez anos, de acordo com a literatura econômica, observa-se um variado número de definições de crescimento ou de desenvolvimento sustentável. Pezzey (1989) cita sessenta definições, Redclift (1987) registrou mais de cem versões, Pearce \& Markandya (1989) mencionam vinte e seis. Sendo que há dois tipos de abordagem do conceito de desenvolvimento sustentável, que são a abordagem econômica global e a abordagem ambiental ou ecológica (Tolmasquim, 1995; Costa, 1995b; Opschoor \& Straaten, 1993; e, Dovers, 1995).

No caso da Amazônia, três concepções de desenvolvimento sustentável divergentes são identificadas na literatura. Na primeira, o desenvolvimento sustentável é baseado em mecanismos que conservem o ambiente e incentivem a participação das comunidades locais, principalmente os pequenos produtores, por meio de diversos programas de utilização da terra. Na segunda, esse tipo de desenvolvimento requer que os estoques de capital natural permaneçam constantes, com o intuito de atender os objetivos das gerações futuras, não permitindo o uso dessa região para fins agrícolas. A terceira concepção é fundamentada no ecodesenvolvimento, que sugere a utilização da 
biomassa como geradora do desenvolvimento sustentável. $\mathrm{O}$ que se pretende nesta última vertente é incentivar a substituição parcial da floresta, sem queimada, por plantações racionais e a utilização racional de parcela da floresta para, através do processamento local, conseguir diversas espécies de produtos (Becker, 1993).

No presente trabalho, adota-se o conceito de desenvolvimento sustentável, baseado na terceira concepção acima citada, que tem como enfoque a substituição parcial da floresta por plantações racionais e a utilização sustentável de parcela das florestas. Esse tipo de desenvolvimento é o mais indicado para o fortalecimento do setor industrial madeireiro, como será enfatizado nos capítulos precedentes, pois garante a sua sustentabilidade no longo prazo, dando oportunidade às gerações presentes e futuras de usufruírem dos recursos florestais.

\subsection{Sustentabilidade e desenvalvimento sustentável}

De uma maneira geral, entende-se por sustentabilidade a possibilidade de continuidade de condições semelhantes ou superiores de vida para um conjunto de pessoas e seus sucessores em determinado ecossistema. O conceito de sustentabilidade é equivalente à idéia de permanência do sistema de vida, expressando o comportamento que busca obedecer às leis da natureza. Trata-se, portanto, do reconhecimento do que é biofisicamente possível em uma perspectiva de longo prazo (Cavalcanti, 1995b, p. 165).

Desse modo, a sustentabilidade pode ser definida como uma quantidade de consumo que se estende indefinidamente sem exaurir os estoques de capital natural. Como exemplo, em um negócio qualquer o estoque de capital compreende os ativos de longo prazo, como imóveis e maquinários, que são usados como meios de produção. $\mathrm{O}$ capital natural é a estrutura do solo e da atmosfera, a biomassa de plantas, animais, etc., 
sendo que todos estes compõem a base de todos os ecossistemas. Esse tipo de capital faz utilização de insumos primários para gerar os serviços do ecossistema e os fluxos de recursos físicos naturais. Tem-se como exemplo de capital natural as florestas, as populações de peixes e os depósitos de petróleo. Os fluxos de produtos oriundos dos capitais naturais citados são as toras de madeira, peixes capturados e petróleo cru bombeado, respectivamente. Pode-se concluir que o fator limitante do desenvolvimento não é o capital criado pelo homem, mas o capital natural remanescente. Ou seja, o que limita a produção de madeira são as florestas que restaram, e não a capacidade das serrarias; a pesca é restringida pelas populações de peixe, e não pelos barcos pesqueiros; e o petróleo cru é limitado por seus depósitos, e não pela capacidade de perfuração e bombeamento (Costanza, 1994).

A sustentabilidade não significa uma economia estática ou estagnada. Deve-se ter atenção, contudo, na distinção entre crescimento e desenvolvimento. $O$ primeiro, que é um aumento em quantidade, não tem possibilidade de ser sustentável indefinidamente em um mundo finito. O segundo - que é uma melhoria da qualidade de vida, sem gerar, necessariamente, uma elevação na quantidade dos recursos consumidos - pode ser sustentável. De acordo com diversos autores, não se verifica nos atuais sistemas econômicos preocupação alguma com a sustentabilidade do sistema de permanência da vida e com a economia que depende dessa permanência (Costanza, 1994, p. 121).

Quando se fala em desenvolvimento sustentável não se devem olhar apenas os aspectos materiais e econômicos, mas um conjunto multidimensional e multifacetado que compõe o fenômeno de desenvolvimento, com os seus aspectos políticos, sociais, culturais e físicos; sendo que a sustentabilidade do todo só pode repousar na sustentabilidade conjunta de suas partes (Stahel, 1995, p.108).

Não existe um único modelo de sustentabilidade para determinada economia nem uma única maneira de se atingir uma vida sustentável, assim como uma 
teoria única de desenvolvimento ecologicamente equilibrado. Existe, na verdade, uma multiplicidade de métodos para entender e investigar tal questão (Cavalcanti, 1995a, p.21).

Há diferença entre sustentabilidade e desenvolvimento sustentável. O primeiro é um objetivo difícil e de longo prazo a ser atingido; e, o segundo é um processo variável de mudança que se deve realizar para se conseguir a sustentabilidade de um determinado sistema (Dovers, 1995)

A adoção do conceito de desenvolvimento sustentável pelos países em desenvolvimento gera a oportunidade de conciliar os objetivos de crescimento econômico, questões sociais e proteção do meio ambiente. O que se pretende não é desacelerar o crescimento, mas conciliar este crescimento com a qualidade ambiental (Kitamura, 1994, p. 19).

\subsection{Os Instrumentos de políticas propostos pela economia ecológica}

Políticas públicas bem-sucedidas conciliam crescimento econômico com preservação ambiental, estimulando o uso ordenado dos recursos naturais, com o objetivo de disponibilizar ao menos a mesma quantidade destes recursos às populações futuras, alcançando um desenvolvimento sustentável. Para tanto, ao serem formuladas, devem ser precedidas de uma política de meio ambiente que organize e coloque em prática as variadas ações que tenham como meta primordial atender às solicitações sociais e a proteção ambiental. Essa política deve estar calcada em instrumentos técnicos, econômicos e regulamentos que amenizem as discordâncias entre os interesses dos agentes do Estado e da sociedade civil.

A gestão ambiental é o mecanismo que tem como função primordial a 
administração dos recursos naturais, procurando encontrar as melhores alternativas para os possíveis problemas que surgem ao gerir tais recursos, principalmente os decorrentes dos conflitos de interesses.

A gestão ambiental tem como objetivos primordiais disciplinar a utilização dos recursos naturais e controlar a qualidade ambiental. Ou seja, a gestão, de modo geral, de um sistema assegura o seu bom funcionamento e seu melhor rendimento, assim como sua continuidade e seu desenvolvimento. Em nível histórico, este conceito foi criado no domínio privado, referindo-se à administração dos bens possuídos por um proprietário (Godard, 1997, p. 209).

Há duas definições para o termo gestão, no que diz respeito aos recursos naturais. A primeira refere-se à concepção mais usada, classificada como a gestão cotidiana dos elementos do meio que são atualmente denominados, de uma forma ou de outra, como recursos naturais. Nesse caso a gestão tem como meta suprir as várias modalidades de demanda com o menor custo, restringir determinados efeitos negativos ou excessivos e considerar os interesses dos diversos atores sociais ou institucionais de acordo com seu peso social ou com suas possibilidades de ação. Essa definição já estabelece dois níveis de gestão, como o que se refere às ações e decisões que dizem respeito a um uso determinado e aquele referente às arbitragens ou combinações encontradas para diminuir tensões ou superar contradições entre os diversos tipos de utilização de um mesmo conjunto de recursos. Na segunda definição, o planejamento de operações de desenvolvimento insere-se em um conjunto mais amplo de gestão contínua de recurso, do espaço e da qualidade do meio ambiente natural e construído (Godard,1997, p. 210).

A noção de sustentabilidade baseava-se no conceito físico - químico e biológico de estoques de recursos. Nos últimos anos, porém, refere-se a um recurso (madeira, por exemplo) ligado a um determinado ecossistema (floresta, por exemplo). 
No que se refere aos recursos renováveis, após a Conferência de Estocolmo, prevaleceu a idéia de que a ênfase das políticas governamentais fosse no estabelecimento de estruturas administrativas do governo, dirigidas para a gestão ambiental - proibições, licenciamento, outorgas, etc. O que se pretende, na verdade, é a produção sustentada de um determinado recurso (madeira) através da racionalização de sua exploração (Neder, 1994, p.119).

Para se administrar um determinado recurso há necessidade de se delimitarem regiões, sendo esta obtida pelo zoneamento econômico-ecológico, que é um instrumento de gestão espacial. O zoneamento tem como intuito realizar um estudo de uma determinada região, de modo que se tenha um ordenamento mais condizente com as características físicas e sócio-econômicas do território. Esse instrumento tem como finalidade a inserção da dimensão ambiental no planejamento, servindo de instrumento para uma ocupação planejada do espaço, além de dar subsídios para um melhor direcionamento das atividades.

O zoneamento econômico-ecológico ${ }^{2}$ oferece auxílio técnico-científico para a execução de planos de ordenação do território. A base deste último é a divisão do espaço geográfico em subespaços ou zonas de intervenção, conforme suas similaridades e contrastes internos, no que se refere a seus atributos ecológicos e sócio-econômicos (CIMA, 1991).

Os resultados dos estudos da estrutura e dinâmica dessas áreas oferecem os elementos necessários para determinar objetivos, escolher critérios, normas e padrões para a planificação das intervenções. Para atingir essas metas, a implementação do zoneamento ecológico-econômico exige uma metodologia que esteja de acordo com a complexidade e abrangência dos temas envolvidos na definição da sustentabilidade, que é o fator primordial para a apropriação dessas áreas.

\footnotetext{
${ }^{2}$ No Brasil, foi legalmente determinado pela Constituição e pelas disposições da Lei 6.938 e Decreto
} 
$\mathrm{Na}$ sua concepção atual, este tipo de zoneamento baseia-se na necessidade de determinar e demarcar ao menos três áreas de acordo com sua categoria de intervenção, tais como: áreas de produção, que possibilitam a produtividade tanto em nível comercial, quanto de subsistência, usando de forma adequada os recursos naturais e considerando a melhoria da qualidade de vida das populações que residem no local, além da conservação do ambiente; áreas desaconselhadas para usos produtivos a curto prazo, que possuem limitações ao uso, necessitando de técnicas de manejo; e áreas especiais, que abrangem unidades de conservação de uso indireto, áreas de preservação permanente, áreas indígenas e sítios de importante interesse histórico, paisagístico e cultural (CIMA, 1991)

Ainda sobre a questão de zoneamento, tem-se como exemplo o caso dos Estados Unidos como uma das experiências mais bem sucedidas de zoneamento agrícola, cuja responsabilidade é dos municípios e estados. Nos países em desenvolvimento, o número de casos bem sucedidos é desprezível, sendo a maior parte em áreas urbanas, que normalmente são combinados com sistema de licenciamentos. No Brasil, o zoneamento também parece ser mais efetivo nas áreas urbanas.

O motivo que está por trás do insucesso das experiências de zoneamento nos países em desenvolvimento, tanto para objetivos ambientais quanto para fins agrícolas, é a descontinuidade nas ações, especificamente na fase de operacionalização dos resultados (Kitamura, 1995, p. 135).

Portanto, o desenvolvimento sustentável propõe uma regulamentação da utilização do território com base em três princípios: "na eficácia, referente à nova racionalidade de poupança de recursos e incorporação de informação e tecnologia nos produtos e processos; na valorização da diferença, referente à identificação e potencialização das vantagens competitivas de cada território; e na descentralização,

99.540/90 que implementou a Comissão Coordenadora do zoneamento ecológico-econômico do Território Nacional. 
constituindo nova forma de governo em parceria, expressão da nova relação públicoprivado" (Encontro de Pesquisadores da Amazônia, 1996).

No presente trabalho, avalia-se como os programas e políticas públicas referentes ao desenvolvimento de Rondônia trataram a questão do desenvolvimento sustentável (capítulo 4). Procura-se, também, verificar como os proprietários de empresas pertencentes ao setor industrial madeireiro deste estado, diante da escassez de diversas espécies florestais no estado, abordam a questão da sustentabilidade do uso de recursos florestais nativos (capítulo 6). 


\section{METODOLOGIA E FONTE DOS DADOS}

Para analisar o processo de ocupação do Estado de Rondônia e a evolução de seu setor industrial madeireiro são utilizados, principalmente, dados secundários do Instituto Brasileiro de Geografia e Estatística (IBGE) e da Federação das Indústrias do Estado de Rondônia (FIERO). Complementando-os, faz-se uso de algumas informações disponíveis na literatura sobre o estado em análise.

Para analisar a conduta e estratégias das empresas industriais quanto ao abastecimento de madeira, bem como seus desempenhos, foi realizada uma pesquisa de campo.

A pesquisa de campo foi feita com empresas pertencentes ao setor industrial madeireiro, que estão cadastradas na Federação das Indústrias do Estado de Rondônia (FIERO) e localizadas em sete municípios, representando, no caso deste trabalho, dois grandes pólos. O pólo 1 corresponde a uma região mais próxima ao Centro-Sul e de mais antiga atividade industrial madeireira e o pólo 2 é de mais recente atividade industrial. O pólo 1 é composto pelos Municípios de Pimenta Bueno, Cacoal, Rolim de Moura e Vilhena; e o pólo 2 incluí Porto Velho, Ariquemes e Ji-Paraná. A figura 1 ilustra a localização dos municípios mencionados no Estado de Rondônia. A

partir das respostas aos questionários, avaliam-se a conduta e o desempenho das empresas quanto ao aspecto da sustentabilidade no uso dos recursos florestais (assunto abordado no Capítulo 6). 


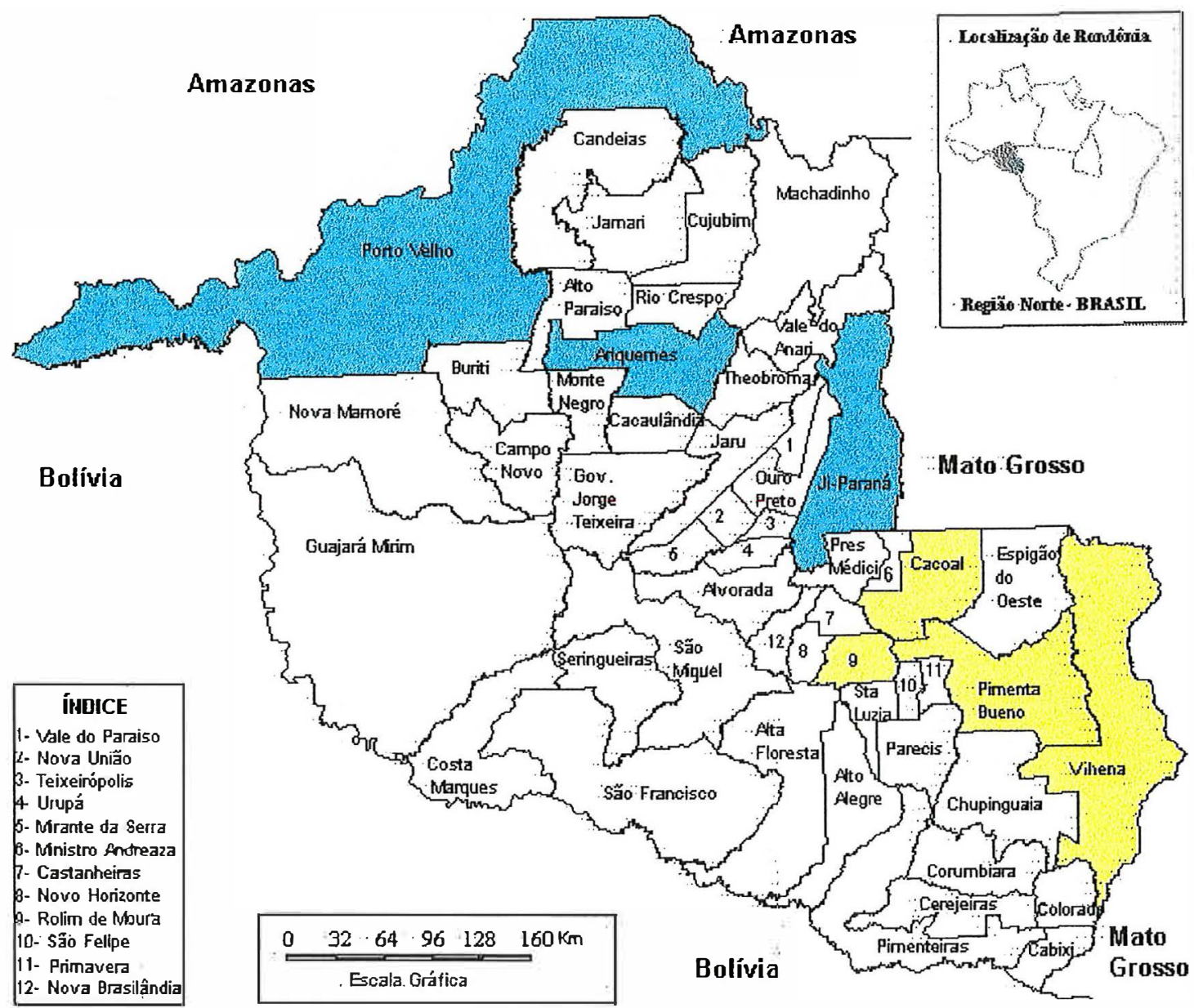

Figura 1 - Região em estudo

A Tabela 1 apresenta o número de empresas do setor industrial madeireiro existentes nos municípios acima mencionados e em todo o Estado de Rondônia em 1997, separando-as em duas categorias: indústria madeireira e indústria moveleira. O primeiro tipo engloba fábricas de desdobramento de madeira, fábricas de estrutura de madeira e artigos de carpintaria, fábricas de chapas e placas de madeira aglomerada ou compensados, e fábricas de artigos diversos de madeira. O segundo tipo inclui fábricas de móveis de diversos tipos. 
Tabela 1 - Número de empresas do setor industrial madeireiro de Rondônia distribuídas segundo seus municípios - 1997.

\begin{tabular}{lccc}
\hline \multicolumn{1}{c}{ Municipios } & Indústria Madeireira $^{1}$ & Indústria Moveleira & Total do Setor \\
\hline Ariquemes & $\mathbf{7 1}$ & $\mathbf{5 3}$ & $\mathbf{1 2 4}$ \\
Ji-Paraná & $\mathbf{4 6}$ & $\mathbf{7 1}$ & $\mathbf{1 1 7}$ \\
Porto Velho & $\mathbf{3 7}$ & $\mathbf{7 9}$ & $\mathbf{1 1 6}$ \\
Rolim de Moura & $\mathbf{2 9}$ & $\mathbf{4 0}$ & $\mathbf{6 9}$ \\
Pimenta Bueno & $\mathbf{2 5}$ & $\mathbf{2 3}$ & $\mathbf{4 8}$ \\
Vilhena & $\mathbf{2 3}$ & $\mathbf{3 9}$ & $\mathbf{6 2}$ \\
Cacoal & $\mathbf{2 4}$ & 34 & 54 \\
Jaru & 20 & 29 & 44 \\
Ouro Preto d' Oeste & 15 & 72 & 462 \\
Demais Municipios & 390 & 472 & 1152 \\
\hline Total & 680 & &
\end{tabular}

Fonte: FIERO (1997)

Nota: 1) A indústria madeireira engloba as fábricas de desdobramento de madeira; fabricas de estrutura de madeira e artigos de carpintaria; fábricas de chapas e placas de madeira aglomerada ou compensadas; e, fábricas de artigos diversos de madeira.

Observa-se que os municípios pesquisados (Ariquemes, Ji-Paraná, Porto Velho, Rolim de Moura, Pimenta Bueno, Vilhena e Cacoal) detinham 51,4\% do total de empresas do setor industrial madeireiro de Rondônia em 1997. Essas percentagens foram de $37,5 \%$ para a indústria madeireira e $71,4 \%$ para a indústria moveleira.

A partir do universo identificado na Tabela 1, definiu-se uma amostra composta por cerca de $20 \%$ das empresas concentradas nos municípios de Ariquemes, Ji-Paraná, Porto Velho, Rolim de Moura, Pimenta Bueno, Vilhena e Cacoal. O tamanho da amostra selecionada está na Tabela 2. Esse percentual foi fixado de modo conservador diante das sugestões possíveis para definir a amostra. 
Tabela 2- Tamanho da amostra pesquisada do setor industrial madeireiro do Estado de Rondônia

\begin{tabular}{lccc}
\hline \multicolumn{1}{c}{ Municipios } & Indústria Madeireira & Indústria Moveleira & Total do Setor \\
\hline Ariquemes & 15 & 11 & 26 \\
Ji-Paraná & 10 & 15 & 25 \\
Porto Velho & 8 & 16 & 24 \\
Rolim de Moura & 6 & 8 & 14 \\
Pimenta Bueno & 5 & 5 & 10 \\
Vilhena & 5 & 8 & 13 \\
Cacoal & 5 & 7 & 12 \\
\hline Total & 54 & 70 & 124 \\
\hline
\end{tabular}

Fonte: Calculado a partir dos dados da Tabela 1. Considerou-se $20 \%$ do universo pesquisado, arredondando os valores para cima.

Segundo Tompkin (1967), há duas formas de cálculo do tamanho da amostra em pesquisa de campo. Primeiro, assumindo-se que somente o número de itens da população é importante, não há necessidade de se conhecer a variância. Neste caso, uma amostra de 50 observações é definida como mínima. Segundo, se a população for menor que 5.000, uma amostra de 50 observações mais $2 \%$ da população é boa. Caso a população seja maior que 5.000, um tamanho razoável é de 50 observações mais $1 \%$ da população. No método em que se conhece a variância, o cálculo do tamanho da amostra é possibilitado pela seguinte fórmula:

$$
\begin{array}{r}
\mathrm{N}=\frac{\mathrm{t}^{2} \cdot \mathrm{V}}{\mathrm{L}^{2}}
\end{array}
$$

Onde $\mathrm{N}$ é o tamanho da amostra; o t é a estatística de student ao nível de significância desejado; V é a variância da população (podendo ser a variância do faturamento anual das empresas); e, L é um valor arbitrário que corresponde ao número de unidades que o pesquisador aceitará como variação a partir da média da característica que interessa na população. 
No trabalho em questão não há conhecimento da variância da população, não podendo ser utilizada a fórmula acima. Optando-se pelo primeiro método, que pressupõe que a variância não é importante, observa-se que o número de empresas madeireiras da amostra deveria ser de aproximadamente 55 empresas e as empresas moveleiras, 57.

Ao se selecionar $20 \%$ da população,-chegou-se a um número bem próximo na amostra para as empresas madeireiras e superior para as empresas moveleiras. Com isto, a amostra selecionada é, no mínimo, boa segundo os critérios de Tompkin (1967)

A população pesquisada foi definida de modo intencional, pois foram considerados apenas sete municípios de Rondônia, representando dois tipos de pólos. A amostra selecionada, porém, foi aleatória, com as empresas localizadas em cada município sendo selecionadas por sorteio. Na seleção da amostra por município, as empresas foram separadas entre empresas madeireiras e moveleiras. A cada empresa, de uma lista fornecida pela Federação das Indústrias do Estado de Rondônia (FIERO), foi atribuído um número e foi realizado o sorteio aleatório.

No apêndice $\mathrm{A}$ está o questionário utilizado na pesquisa. $\mathrm{O}$ mesmo contém questões visando caracterizar a empresa, levantar informações sobre o tipo e volume da produção, o tipo e o abastecimento de madeira consumida, sobre a efetividade da fiscalização do IBAMA e sobre estratégias a serem adotadas no caso de escassez de toras de madeira. As questões foram definidas de modo a avaliar, no mínimo, quatro aspectos:

- o desempenho das empresas segundo o pólo em que se localizam;

- o processo de troca de proprietários das empresas;

- a escassez de matéria-prima; e, 
- a eficácia das ações dos órgãos ambientais em garantir a exploração florestal sustentável.

O questionário foi aplicado diretamente ao proprietário ou responsável pela empresa em julho de 1998 e em fevereiro de 1999. 


\section{POLÍTICAS PÚBLICAS E OCUPAÇÃO DO ESTADO DE RONDÔNIA}

Neste capítulo utilizam-se os conceitos de desenvolvimento sustentável, sustentabilidade e o método de análise da economia ecológica, enfocando especialmente as questões de gestão ambiental e zoneamento ecológico-econômico, para avaliar a evolução e os impactos sobre os recursos florestais das políticas públicas referentes a Rondônia, em especial as referentes à ocupação deste estado.

Para tanto, o capítulo é composto de seis itens. O item 4.1 descreve alguns aspectos do processo de ocupação da Amazônia, com ênfase na ocupação do atual Estado de Rondônia antes da década de 70. O item 4.2 aborda o processo migratório em direção àquele estado, a partir de 1970, e seu impacto sobre as florestas nativas. O item 4.3 analisa o POLONOROESTE. Os itens 4.4, 4.5 e 4.6 tratam de novas políticas e programas implementados a partir do final da década de 80, que tornaram explícitas as preocupações com a preservação e conservação ambiental no processo de desenvolvimento regional. No item 4.4 é abordado o Programa de Zoneamento Econômico Ecológico para a Amazônia Legal e no item 4.5 analisa-se o Plano Agropecuário e Florestal de Rondônia (PLANAFLORO). O item 4.6 discute a sistemática e alguns efeitos do ICMS Ecológico em Rondônia. 


\subsection{A Amazônia e o atual Estado de Rondônia}

No Brasil, com o intuito de coordenar os planos governamentais para a Região Amazônica, implantou-se em 1953, no segundo Governo de Getúlio Vargas, a Superintendência do Plano de Valorização Econômica da Amazônia (SPVEA). Esse órgão foi substituído, em 1966, pela Superintendência de Desenvolvimento da Amazônia (SUDAM) e esta, para efeito de ação governamental, delimitou a Amazônia Legal. Essa região estende-se por uma área de 5.217 .423 km (SUDAM, 1990, p.3), o que eqüivale a aproximadamente $61 \%$ da área territorial total do Brasil, e é composta por nove estados: Acre, Amapá, Amazonas, Tocantins, Maranhão, Mato Grosso, Pará, Rondônia e Roraima. No caso do Estado do Maranhão, apenas parte de sua área pertence à Amazônia Legal.

Na segunda metade da década de 60, mais especificamente no Governo Castelo Branco, duas das metas primordiais a serem atingidas eram resolver os problemas das "tensões sociais" existentes no Nordeste e Sul do País, referentes aos conflitos de terras, e desenvolver a Amazônia, através de sua integração ao resto do País. Para tanto, instituíram-se algumas políticas com o objetivo de facilitar o assentamento, na Amazônia, de um grande contingente populacional e favorecer certos tipos de atividades econômicas.

Os projetos incluíam, entre outros, um ambicioso programa para a construção de estradas que ligassem a Amazônia às regiões Nordeste e Sul do País, planos para a sua colonização agrícola e incentivos fiscais que beneficiassem a criação de novas atividades, tanto agrícolas quanto industriais.

O Estado de Rondônia, possuindo uma extensão de 243 mil km² e localizado no sudoeste amazônico brasileiro, sofreu grandes impactos econômicos, sociais e ambientais com a implantação dos programas que visavam ao desenvolvimento 
regional. De grande importância foi o término da construção da rodovia Cuiabá-Porto Velho (BR-364), e sua posterior pavimentação no âmbito do POLONOROESTE, que intensificaram o fluxo migratório em direção a este estado. Os migrantes foram atraídos pelo potencial econômico de Rondônia, como as terras inexploradas disponíveis à agricultura, à pecuária, à extração de madeira, à exploração extrativa da borracha, e à extração de minérios, como o ouro e a cassiterita.

No período anterior à expansão da malha rodoviária, o acesso a Rondônia era extremamente difícil por via terrestre. A ligação desse estado com o resto do país se dava, em sua maior parte, por via fluvial. Em 1950, o povoamento em Rondônia era extremamente pequeno, com 0,15 indivíduo por $\mathrm{km}^{2}$. A população concentrava-se no norte do estado, nas localidades próximas da Estrada de Ferro Madeira-Mamoré, que foi construída no início do século com o intuito de facilitar o comércio do Brasil com a Bolívia.

A economia do então chamado território do Guaporé baseava-se no extrativismo da borracha e da castanha. A exploração da floresta, por parte da população local - por meio da caça, da pesca e da colheita de produtos vegetais - tinha como finalidade a subsistência, não alterando significativamente o ambiente florestal; e, a lavoura itinerante era insignificante.

Na Tabela 3, observa-se a evolução do crescimento populacional de Rondônia. Em 1960 a população total deste Estado era de 69.792 habitantes, passando para 1.231.007 habitantes, em 1996. A densidade demográfica passou de 0,29 habitante/km² em 1960 para 5,07 hab/km² em 1996. 
Tabela 3- Evolução da população de Rondônia, entre 1950 e 1996, segundo seu domicílio.

\begin{tabular}{ccccccccccccc}
\hline Ano & \multicolumn{2}{c}{1950} & \multicolumn{2}{c}{1960} & \multicolumn{2}{c}{1970} & \multicolumn{2}{c}{1980} & \multicolumn{2}{c}{1991} & \multicolumn{1}{c}{1996} \\
\hline & Pop & $\%$ & Pop & $\%$ & Pop & $\%$ & Pop & $\%$ & Pop & $\%$ & Pop & $\%$ \\
\hline Zona Urbana & 13.816 & 37,4 & 30.186 & 43,2 & 59.564 & 53,6 & 228.168 & 46,4 & 658.172 & 58,2 & 762.864 & 61,97 \\
Zona Rural & 23.119 & 62,6 & 39.606 & 56,8 & 51.500 & 46,4 & 262.857 & 53,6 & 472.702 & 41,8 & 468.143 & 38,03 \\
\hline Total & 36.935 & 100 & 69.792 & 100 & 111.064 & 100 & 491.025 & 100 & 1.130 .874 & 100 & 1.231 .007 & 100 \\
\hline
\end{tabular}

Fonte: SEDAM (1996); e, FIBGE (1996).

As taxas anuais geométricas de crescimento da população nos períodos 1950/1960, 1960/1970, 1970/1980, 1980/1991 e 1991/1996 foram, respectivamente: $6,57 \%, 4,76 \%, 16,03 \%, 7,88 \%$ e $1,71 \%$. Constata-se, portanto, que os anos de maior crescimento da população foram os das décadas de 70 e 80 , que coincidem com a expansão da malha rodoviária e os projetos oficiais e particulares de colonização no estado.

\subsection{Processo de migração e seu impacto sobre as floresta nativas}

O intenso fluxo migratório verificado no Estado de Rondônia a partir de 1970 pode ser justificado tanto por fatores de expulsão quanto por fatores de atração. No caso dos fatores de atração destacam-se o término da construção da BR-364, que possui em certos trechos um solo relativamente fértil; e a possibilidade de se conseguirem lotes de terrenos de 100 hectares, com serviços básicos e infra-estrutura necessária, por preços baixos nos diversos projetos de colonização. Em relação aos fatores de expulsão, o principal está relacionado à diminuição das oportunidades de trabalho observada no Sul e Sudeste, em decorrência da difusão dos sistemas mecanizados para a produção de soja; às intensas geadas nas plantações de café; e, à fragmentação da propriedade da terra (Mahar, 1990).

Com o objetivo de assentar os migrantes, o Governo Federal, durante a 
década de 70, criou os Projetos Integrados de Colonização (PIC), destinados aos agricultores sem terra e de baixa renda. Os principais foram o PIC Ouro Preto, PIC Ji Paraná, PIC Paulo Assis Ribeiro, PIC Adolfo Rohl e PIC Sidney Girão. Também implementaram-se os Projetos de Assentamento Dirigido (PAD). Os órgãos oficiais, porém, não conseguiram atender a demanda dos colonos por lotes, o que gerou conflitos nas áreas dos projetos de colonização.

O acelerado crescimento demográfico e a colonização descontrolada causaram efeitos danosos na floresta pluvial, percebendo-se níveis altíssimos de desmatamento em certas regiões dentro do estado. O município de Cacoal, que apresenta uma superfície de 80.000 hectares, tinha no ano de 19752.150 hectares de sua área desmatada. Em 1978, o total desmatado era da ordem de 66.950 hectares (Mahar, 1990). Grande parte do desmatamento deveu-se às pressões para implantação de novas áreas para culturas nas regiões dos projetos de colonização do governo ao longo das principais estradas.

Os projetos de colonização não se preocuparam em garantir a sustentabilidade do recurso florestal, apesar da legislação florestal federal vigente que exigia, na época, que $50 \%$ da propriedade fosse mantida como Reserva Legal ${ }^{3}$ (área onde é proibido o corte raso da floresta).

Em geral, mais de $50 \%$ da propriedade era desmatada. A deficiência dos órgãos públicos responsáveis pelas questões ambientais em executar uma efetiva política de controle do desmatamento foi um dos motivos de grande relevância que estava por trás da não manutenção da reserva legal. Um dos pontos que deve ser ressaltado é o conflito que existia entre a legislação florestal e outros tipos de legislação. Por exemplo, enquanto a legislação florestal proibia o desmatamento em mais de $50 \%$ de cada propriedade, o Estatuto da Terra de 1964 "incentivava" o desmatamento como uma das

\footnotetext{
${ }^{3}$ Atualmente, de acordo com a Medida Provisória de № 1.511-13, de 25 de junho de 1997, em propriedades constituídas de fitofisionomias florestais, na Região Norte e em parte do Centro-Oeste, não
} 
formas de obtenção do direito de posse da terra.

Na verdade, o que se constata é que o valor econômico imediato da floresta passa a ser considerado como sendo menor que o valor de utilizações alternativas do solo. Este ponto era inclusive sustentado pelos inadequados mecanismos fiscais, como o Imposto Territorial Rural, cujo valor era maior para áreas de floresta, já que a sua derrubada era considerada uma benfeitoria incorporada à terra. Essa incoerência está sendo modificada, principalmente pela Lei Federal 6393/97. Ainda é mantida, porém, a portaria do INCRA para a implantação de projetos de colonização, que induzem a práticas de desmatamento com finalidade de benfeitoria.

\subsection{POLONOROESTE}

No início da década de 80, o Governo Federal, receoso com a forma existente de ocupação da região noroeste do Brasil (Rondônia e parte do Mato Grosso), que perfaz uma área de $410.000 \mathrm{~km}^{2}$, e considerando a reduzida capacidade dos governos estaduais em lidar com as necessidades de ordenamento e auxílio sócio-econômico das populações que ingressavam nesta região, implementou o POLONOROESTE (em 25 de maio de 1981). Este programa foi parcialmente financiado pelo Banco Mundial, tendo como principais objetivos: obter uma maior integração nacional, por meio da pavimentação da BR-364 no trecho Cuiabá-Porto Velho; favorecer a adequada ocupação da região que fazia parte do programa; abrigar populações economicamente marginalizadas de outras regiões; conseguir o aumento significativo na produção da região e na renda de sua população; auxiliar na diminuição das desigualdades de desenvolvimento, aos níveis inter e intra-regionais; e, possibilitar o crescimento da produção em harmonia com as preocupações de preservação do sistema ecológico e da 
proteção às comunidades indígenas (SEPLAN, 1990).

$\mathrm{Na}$ vigência do POLONOROESTE, em decorrência especialmente da conclusão da pavimentação da BR-364 em setembro de 1984, nova onda migratória direcionou-se ao estado e, com esta, a ampliação de novas atividades que antes vinham se comportando timidamente. O destaque é atribuído ao setor industrial madeireiro. Em 1973, o Estado de Rondônia contava com aproximadamente 32 serrarias $^{4}$ e, em 1982, com 387. No final da década de 80 , o número de serrarias atuando no estado era da ordem de 1.200 (Lisboa, 1990; UFRRJ/IBDF, 1983).

Outro ponto que deve ser ressaltado se refere ao aumento expressivo na produção de madeiras em tora no Estado de Rondônia. Conforme a Tabela 4, esta produção elevou-se de $318.109 \mathrm{~m}^{3}$, em 1979 , para $4.744 .907 \mathrm{~m}^{3}$, em 1992 . Nos anos posteriores houve decréscimo, quando comparados ao ano de 1992. Observa-se, porém, uma pequena elevação, entre os anos de 1994 e 1995 , de $1.126 .923 \mathrm{~m}^{3}$ para 1.457 .132 $\mathrm{m}^{3}$

\footnotetext{
4 Segundo Freitas \& Soares (1994, p. 80), este setor foi um dos mais beneficiados com o POLONOROESTE, como consequiência da expansão da malha rodoviária deste estado na vigência deste programa e pela abundância de mão-de-obra, como a dos colonos dos projetos de colonização.
} 
Tabela 4- Produção de madeiras nativas nos estados da Região Norte (em $\mathrm{m}^{3}$ toras)

\begin{tabular}{cccccccc}
\hline & \multicolumn{7}{c}{ Estados } \\
\cline { 2 - 8 } Anos & Pará & Rondônia & Amazonas & Amapá & Acre & Roraima & Tocantins \\
\hline 1979 & 7.169 .579 & 318.109 & 398.376 & 381.310 & 78.818 & 54.680 & - \\
1980 & 10.283 .944 & 307.001 & 325.013 & 400.400 & 94.274 & 72.857 & - \\
1981 & 11.670 .915 & 491.914 & 364.176 & 426.000 & 108.393 & 84.496 & - \\
1982 & 12.352 .785 & 581.372 & 662.725 & 873.716 & 131.511 & 50.300 & - \\
1983 & 13.785 .048 & 768.712 & 384.649 & 951.133 & 184.235 & 20.426 & - \\
1984 & 14.072 .018 & 1.256 .307 & 1.316 .589 & 500.360 & 231.853 & 11.730 & - \\
1985 & 16.361 .711 & 1.320 .213 & 1.382 .218 & 413.440 & 275.716 & 39.920 & - \\
1988 & 28.427 .617 & 2.190 .940 & 552.000 & 471.280 & 310.133 & 56.003 & - \\
1989 & 43.138 .701 & 2.255 .352 & 626.011 & 549.284 & 309.734 & 37.273 & 569.896 \\
1991 & 28.369 .671 & 1.027 .302 & 180.852 & 353.192 & 304.722 & 35.897 & 483.380 \\
1992 & 31.734 .992 & 4.744 .907 & 162.011 & 316.959 & 286.114 & 37.650 & 516.770 \\
1993 & 44.177 .956 & 1.353 .456 & 4.362 .088 & 332.648 & 357.604 & - & 437.497 \\
1994 & 44.538 .678 & 1.126 .923 & 496.611 & 330.033 & 372.753 & 16.700 & 277.471 \\
1995 & 43.919 .777 & 1.457 .132 & 530.603 & 352.104 & 321.308 & - & 247.508 \\
\hline
\end{tabular}

Fonte: Anuário Estatístico do Brasil (vários anos)

Outros fatores, além da expansão da malha rodoviária, que estão por trás destes incrementos na produção de madeiras em toras são os incentivos econômicos diretos concedidos pela SUDAM, visando, na maior parte das vezes, à exportação de madeira, principalmente, da espécie mogno; e a exaustão dos recursos florestais da Região Sul, que antes participavam com 42,37\% (em 1979) da produção nacional, caindo para 7,06\%, em 1995. No caso da Região Norte, observa-se o processo inverso (Tabela 5).

Tabela 5- Produção de madeira nativas no Brasil e Regiões.

\begin{tabular}{|c|c|c|c|c|c|c|c|c|}
\hline \multirow[b]{2}{*}{ Regiões } & \multicolumn{2}{|c|}{1979} & \multicolumn{2}{|c|}{1985} & \multicolumn{2}{|l|}{1994} & \multicolumn{2}{|c|}{1995} \\
\hline & $\begin{array}{l}\text { Volume } \\
\left(\mathrm{m}^{3} \mathrm{de}\right. \\
\text { tora) }\end{array}$ & $\%$ & $\begin{array}{l}\text { Volume } \\
\left(\mathrm{m}^{3} \mathrm{de}\right. \\
\text { tora) }\end{array}$ & $\%$ & $\begin{array}{c}\text { Volume } \\
\text { ( } \mathrm{m}^{3} \text { de tora) }\end{array}$ & $\%$ & $\begin{array}{c}\text { Volume } \\
\left(\mathrm{m}^{3} \text { de }\right. \\
\text { tora) }\end{array}$ & $\%$ \\
\hline Norte & 8.400 .872 & 26,63 & 19.793 .218 & 46,16 & 47.159 .169 & 75,42 & 46.828 .504 & 76,03 \\
\hline Nordeste & 5.576 .102 & 17,67 & 8560.163 & 19,96 & 5.755 .983 & 9,21 & 5.578 .498 & 9,06 \\
\hline Sudeste & 1.238 .827 & 3,93 & 1.869 .137 & 4,36 & 393.431 & 0,63 & 279.796 & 0,45 \\
\hline Sul & 13.366 .298 & 42,37 & 8.910 .036 & 20,78 & 4.779 .181 & 7,64 & 4.350 .020 & 7,06 \\
\hline Centro-Oeste & 2.968 .028 & 9,41 & 3.751 .643 & 8,75 & 4.439 .056 & 7,10 & 4.551 .452 & 7,39 \\
\hline Brasil & 31.550 .127 & 100,00 & 42.884 .197 & 100,00 & 62.526 .820 & 100,00 & 61.588 .270 & 100,00 \\
\hline
\end{tabular}


Em termos dos resultados do POLONOROESTE, constata-se que, no período de 1982 a 1985, este apresentou desempenho considerável no que diz respeito aos projetos de investimentos e obras. Houve destaque à pavimentação da BR-364; a construção de 23 núcleos urbanos, com o objetivo de apoiar as comunidades rurais; as construções de escolas, postos de saúde, hospitais, estradas vicinais, escritórios de órgãos públicos, etc. Contudo, em termos de propostas de desenvolvimento social e ecológico harmônicos, as atuações tanto do Governo Federal quanto do Estadual (criado em 1982) não estavam de acordo com as expectativas e não atingiram as metas propostas no programa. As justificativas centralizavam-se na falta de pessoal e/ou qualificação técnica suficiente para atingir tais objetivos, tendo como exemplo o antigo IBDF, que para realizar o controle e fiscalização das unidades de conservação e desmatamento contava com apenas oito fiscais no estado (PLANAFLORO, 1990). Para se ter uma idéia, a área total desmatada no estado era de $13.955 \mathrm{~km}^{2}$ em 1982, elevando-se para 27.658 $\mathrm{Km}^{2}$ em 1985 (Diegues, 1993).

Portanto, o que se percebe no POLONOROESTE é que não houve preocupação ambiental nas decisões sobre pesquisa, alocação de crédito e na extensão rural, a qual daria suporte ao desenvolvimento e a uma melhor utilização dos recursos naturais.

\subsection{Programa de zoneamento econômico-ecológico para a Amazônia Legal}

Alguns dos objetivos da SUDAM, em 1975, destinados à Amazônia Legal eram fazer o zoneamento territorial, planejar a exploração racional da floresta, adotar medidas preservacionistas e intensificar a pesquisa florestal. Essa medidas, porém, não se concretizaram devido à falta de decisão política. Após 15 anos, chegou-se à conclusão da importância do zoneamento do espaço geográfico amazônico com o intuito de 
implementar as diversas atividades produtivas ou não. Na verdade, os incentivos da SUDAM à atividade madeireira eram mais voltados à promoção da extração de madeira, não havendo a devida preocupação com a liberação de recursos que visassem a sustentabilidade da atividade no longo prazo.

Uma das formas de se obter o desenvolvimento sustentável da Amazônia é por meio do planejamento do uso do meio ambiente, de modo a conciliar seu potencial natural às necessidades da população regional. Este tipo de planejamento é, normalmente, baseado em um zoneamento que melhor determine a localização das atividades (Pandolfo, 1995, p.106; Uhl \& Vieira, 1991, p.115; Kitamura, 1995, p. 134).

Em 1991, o Governo Federal implantou, para a Amazônia Legal, o Programa de Zoneamento Econômico-Ecológico. Contudo, o programa não é preciso pelo fato de expressar uma visão ambígua quanto à concepção de zoneamento. Ou seja, ao mesmo tempo que o zoneamento Econômico-Ecológico é entendido como um mecanismo de transformação da Amazônia em uma região intocável, são liberadas áreas para o uso predatório (Encontro de Pesquisadores da Amazônia, 1996, p: 5)

No que diz respeito ao Estado de Rondônia, era o único pertencente à Amazônia Legal que possuía, no início da década de 90, um Zoneamento SócioEconômico-Ecológico. Este zoneamento pôde ser obtido pela criação do Plano Agropecuário e Florestal de Rondônia (PLANAFLORO).

\subsection{Plano Agropecuário e Florestal de Rondônia (PLANAFLORO)}

Para se obter um ordenamento da ocupação de acordo com critérios mais sustentáveis, houve a preocupação do Governo Estadual, por volta de 1986, em corrigir alguns pontos do POLONOROESTE, por meio da incorporação da idéia de ordenamento 
territorial, numa visão de sustentabilidade a longo prazo (seguindo uma visão da Economia Ecológica, como exposta no item 2.5). Com a criação do Plano Agropecuário e Florestal de Rondônia (PLANAFLORO) foi feita a $1^{\text {a }}$ aproximação do Zoneamento Sócio-Econômico-Ecológico ${ }^{5}$ do estado.

Em sua origem, o PLANAFLORO foi uma proposta que teve como intuito modificar falhas de concepção, operacionalização, responsabilidades institucionais e execução do POLONOROESTE. Politicamente, o PLANAFLORO é um plano que atende às solicitações do Governo Estadual em substituir o POLONOROESTE, que estava em processo de encerramento.

Na prática, o PLANAFLORO tem como objetivo a busca do equilíbrio entre o desenvolvimento e a preservação do meio ambiente. O Plano foi estabelecido em junho de 1988, mas só implantado em dezembro de 1991. De acordo com o zoneamento, a divisão territorial se deu em seis zonas, com as seguintes destinações: zona de intensificação da exploração agropecuária (abrangendo 6.195.000 ha), zona de pequenos produtores em coletividade (3.015.000 ha), zona ribeirinha (579.000 ha), zona extrativista (3.500.000 ha), zona de manejo florestal (3.601.000 ha) e zona de conservação e preservação (abrangendo 7.404.000 ha), segundo informações de Encontro de Pesquisadores da Amazônia (1996); Diegues (1993); e, FIERO (1995).

As propostas do PLANAFLORO têm como base a estratégia de alterar as políticas públicas até então vigentes no estado, que não deram prioridades às questões ambientais. As principais propostas são:

$$
\begin{aligned}
& \text { “implementar um conjunto de mudanças em políticas, } \\
& \text { legislação e em programas de investimentos públicos, criando uma }
\end{aligned}
$$

s O Zoneamento Sócio-Econômico-Ecológico é um instrumento que oferece oportunidades de crescimento econômico e uso dos recursos naturais através da qualidade ambiental. Ou seja, é um instrumento para delimitar o desenvolvimento em base sustentáveis (Encontro de Pesquisadores da Amazônia, 1996). Ver item 2.5 do capitulo 2. 
estrutura de incentivos que seja coerente com o desenvolvimento sustentável em Rondônia; preservar a biodiversidade do estado, enquanto gera a base para o uso dos recursos naturais para o benefício econômico direto da população local; proteger os limites das Unidades de Conservação, Áreas Indígenas, Florestas Públicas e Reservas Extrativistas, contendo e prevenindo o desmatamento ilegal, o transporte ilegal de madeiras e as queimadas; criar intensivo sistema integrado de produção em regiões que sejam aptas à agricultura permanente e à agrofloresta, e sistema para manejo sustentável da floresta e extração de produtos florestais não madeireiros, em outras áreas que terão que ficar sob cobertura de floresta natural; auxiliar investimentos prioritários em infraestrutura sócio-econômica e serviços necessários à execução do zoneamento, em áreas que já estão desmatadas e ocupadas; assegurar a capacidade técnica e operacional das instituições do estado, especialmente as responsáveis pela agricultura e serviços de apoio florestal, e a proteção e o manejo florestal das Unidades de Conservação federais e estaduais e Áreas Indígenas" (Cury, 1996).

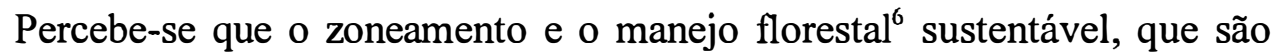
condições sine qua non para o desenvolvimento sustentável, estão presentes nas propostas do PLANAFLORO.

Quanto aos resultados alcançados pelo PLANAFLORO até o ano de 1996, observa-se que os mais significativos estão centrados nas questões ambientais - ao contrário do que se verificou no POLONOROESTE - destacando-se os seguintes:

"regularização e criação de Unidades de Conservação e de Reservas extrativistas; realização da 2 a Aproximação do Zoneamento; revisão dos instrumentos de políticas públicas; capacitação do pessoal em Sistema de Informação Geográfica (S.I.G.) e gestão de espaço; validação dos sistemas agroflorestais e sistemas alternativos de produção pelo projeto de Iniciativas Comunitária (PIC), atualmente Programa de Apoio às Iniciativas Comunitárias (PAICs); busca de alternativas econômicas sustentáveis às populações indígenas; implantação de um sistema de unidades de conservação de uso indireto; capacitação de técnicos em diversas áreas; implantação de programas de educação ambiental, não formal" (FIERO, 1997, p. 73).

Apesar dos resultados obtidos no PLANAFLORO, há alguns problemas 
ainda pendentes que impedem que certas metas sejam atingidas. Eles surgem nos processos de desapropriação de imóveis rurais, na implementação de novos projetos de assentamento, na alienação de terras públicas e na regularização fundiária, pelos seguintes motivos: "desconhecimento da existência de Unidades Estaduais de Conservação e não obediência às restrições definidas no zoneamento sócio-econômicoecológico; destinações de área ao assentamento de pequenos agricultores em regiões de solo de baixa aptidão agrícola; aceitação do desmatamento, associado à introdução de pastagens artificiais como forma de obter o reconhecimento de posse, mesmo em áreas de uso restrito (zonas 4, 5 e 6) e em unidades estaduais de conservação. Esse procedimento é decorrente da ação normativa do INCRA que, aplicável ao caso de Rondônia, promove degradação ambiental e desrespeita o estabelecido no Código Florestal" (RIBAS, 1997, p.34).

Para evitar esses desencontros entre os objetivos do INCRA e as propostas do PLANAFLORO, procedeu-se à assinatura, em meados de 1995, de um convênio entre o INCRA e o Governo do Estado, em que se estabeleceu a importância do cumprimento das diretrizes do zoneamento sócio-econômico-ecológico. Também foi proposta a elaboração prévia de Estudos de Impacto Ambiental (EIA) e estudos de viabilidade agroflorestal como condições básicas para a implantação de novos projetos de assentamento pelo INCRA.

No convênio foi definido um plano de trabalho, dando ênfase às seguintes medidas: transferências de terras públicas federais da União para o Estado, com o intuito de criação de Unidades de Conservação; e, avaliar as zonas 1 e 2 do zoneamento sócioeconômico-ecológico com o objetivo de checar as grandes propriedades improdutivas, que poderiam ser passadas ao patrimônio público, para fins de reforma agrária.

As propostas do convênio não foram colocadas em prática, havendo ainda a implantação dos projetos de assentamento de maneira independente das orientações

6 Estes itens estão detalhados na seção 4.4. 
dos organismos do Estado. Outro fato que deve ser ressaltado é a existência da Instrução Normativa 03 de 08/09/92, que aceita o desmatamento vinculado à introdução de pastagens artificiais como meio de obtenção da posse da terra.

Além do exposto, outro ponto que envolve mais diretamente a questão da sustentabilidade do setor industrial madeireiro diz respeito ao licenciamento ambiental.

De maneira geral, o licenciamento é uma autorização concedida para a implantação de uma determinada atividade. O licenciamento, ao ser concedido, deve estar de acordo com o zoneamento ambiental vigente na região e considerar a permanência dos padrões de qualidade para o meio receptor dos efluentes ou emissões da instalação (água, ar e solo).

No Estado de Rondônia, O IBAMA e a SEDAM são os responsáveis pela concessão de autorização e licenciamento de ações que potencialmente tragam danos ao meio ambiente. A divisão das tarefas entre dois órgãos distintos gera conflitos nas ações. Ou seja, os licenciamentos do IBAMA, algumas vezes, não são condizentes com o enunciado na legislação estadual do zoneamento sócio-econômico-ecológico, presente na Lei Complementar de nº 52, de 20/12/91, além de desconsiderar, também, a presença de Unidades de Conservação.

Para evitar esses conflitos, o IBAMA tem se unido com a SEDAM, por meio de convênios, com o objetivo de descentralizar determinadas funções de licenciamento. A responsabilidade de proteção e fiscalização ambiental é dividida entre o IBAMA, a SEDAM e o Pelotão Florestal, abrindo também a possibilidade de participação de governos municipais e da sociedade civil.

A baixa incidência de recursos técnicos e de pessoal tornam a política de licenciamento de desmatamento e de exploração florestal bastante deficiente, o que gera, muitas vezes, um licenciamento que não condiz com o disposto no zoneamento. 
Segundo RIBAS (1997), há casos documentados de autorização de desmatamento e exploração madeireira, liberadas pelo IBAMA e SEDAM, em áreas de Reservas Extrativistas, além de outras unidades de conservação, que foram criadas por decreto.

A deficiência na vistoria e o não acompanhamento das licenças para exploração seletiva, manejo florestal e reposição florestal, além da falha no controle da expedição das autorizações para o transporte de Produtos Florestais, incentivam a retirada ilegal em áreas indígenas e em outras unidades de conservação.

Além do descrito acima, a exigência de estudo de impacto ambiental não tem sido conduzida em todas as áreas delimitadas na legislação, com especial destaque aos programas de assentamento agrário e à implantação de obras de infra-estrutura.

Se, por um lado, os órgãos públicos conseguiram, de certa forma, auxiliar na desaceleração do ritmo do desmatamento do Estado; por outro, os empresários que compõem o setor industrial madeireiro do Estado de Rondônia ainda não se conscientizaram da necessidade de realização do manejo florestal ou do reflorestamento. Os órgãos responsáveis pelas questões ambientais têm uma parcela de culpa, constatada pela falta de coerência nas medidas que vêm sendo adotadas.

\section{6-ICMS ecológico em Rondônia}

O ICMS ecológico é um instrumento de gestão ambiental, sendo, portanto, uma maneira preventiva e alternativa de se evitarem danos ao meio ambiente. Por meio do imposto, possibilita-se uma melhor disciplina no gerenciamento do meio ambiente. 
Este instrumento originou-se da procura de alternativas para $o$ financiamento público das administrações municipais que, em geral, possuíam uma utilização restrita de seu espaço territorial para a implantação de determinadas atividades que pudessem causar danos aos ecossistemas. A criação desse subsídio gera um estímulo ao município para melhor gerir as áreas destinadas à preservação ou conservação.

A sua implantação tornou-se viável, no Sistema Tributário Nacional, por meio do artigo 158 da Constituição Federal, onde se estabelece o direito de os municípios receberem $25 \%$ do produto de arrecadação do ICMS, sendo que $3 / 4$ da distribuição desse montante se faz de acordo com o valor fiscal adicionado pelos municípios e o restante 1/4 do valor da quota-parte dos municípios é distribuído segundo critérios dos estados, através de lei estadual complementar específica. A divisão dos recursos do 1/4 da quota-parte dos municípios pode contemplar o item ICMS Ecológico, que define os critérios ambientais para o repasse dos recursos aos municípios.

De um modo geral, em todas as experiências de ICMS Ecológico no Brasil há liberação de recursos para os municípios que possuem Unidades de Conservação e outras áreas que são especialmente protegidas. As divergências surgem em outros pontos, como: forma de cálculo; considerar apenas as Unidades de Conservação que estão sob a responsabilidade do Estado, ou também as municipais e federais; e, incluir indicador de qualidade das Unidades de Conservação.

Os estados que possuem o ICMS ecológico são Paraná, São Paulo, Rio Grande do Sul, Minas Gerais e Rondônia. Há planos para o funcionamento, também, nos estados de Santa Catarina, Espírito Santo, Ceará, Goiás, Rio de Janeiro e Mato Grosso do Sul (Bacha e Shikida, 1999).

No caso de Rondônia, que é o objetivo de análise deste trabalho, o ICMS Ecológico foi implantado pela Lei Complementar Estadual de nํㅜ 147/96, em substituição a Lei $n^{0}$ 115/94. Passou-se, então, a alocar 5\% do percentual de direito dos municípios 
do Estado na participação do ICMS aos municípios que abriguem unidades de preservação ou conservação ambiental. A Tabela 6 mostra os critérios para a repartição de $25 \%$ do ICMS entre os municípios de Rondônia de acordo com as duas Leis Complementares acima citadas

Tabela 6- Repartição de $25 \%$ do ICMS entre os municípios de Rondônia de acordo com as Leis Complementares n-115/94 e 147/96

\begin{tabular}{ccc}
\hline Critério & Lei $115 / 94$ & Lei $147 / 96$ \\
\hline Valor adicionado & $75 \%$ & $75 \%$ \\
\hline $\begin{array}{c}\text { Proporcional à superfície } \\
\text { territorial do município }\end{array}$ & $0,5 \%$ & $0,5 \%$ \\
\hline $\begin{array}{c}\text { Proporcional à produção } \\
\text { agrícola, pecuária e extrativa do } \\
\text { município }\end{array}$ & $5,0 \%$ & $5,0 \%$ \\
\hline $\begin{array}{c}\text { Proporcional à produção do } \\
\text { município }\end{array}$ & $0,5 \%$ & $0,5 \%$ \\
\hline Partes iguais & $19,0 \%$ & $14 \%$ \\
\hline $\begin{array}{c}\text { Proporcional à ocupação do } \\
\text { município com Unidades de } \\
\text { Conservação }\end{array}$ & $5,0 \%$ \\
\hline
\end{tabular}

Fonte: Assembléia Legislativa do Estado de Rondônia.

Os municípios que têm direito ao ICMS Ecológico são os que possuem Unidades de Conservação. Estas últimas, segundo a Lei Complementar mencionada, são: “áreas protegidas e estabelecidas em ecossistemas significativos do território estadual no âmbito administrativo do Governo Federal, Estadual e Municipal, nas categorias de Estação Ecológica, Reserva Biológica, Parque, Monumento Natural, Área de Proteção Ambiental, Reserva Indígena, Floresta, Reservas Extrativista e outras inclusas em quaisquer categorias de Unidade de Conservação, criadas por leis ou decretos municipal, estadual e federal" (Artigo 3ํ da Lei Complementar № 147, de 15 de janeiro de 1996).

De acordo com a Lei Complementar № 147, a parcela que cada município terá direito é definida pelo órgão responsável pelo gerenciamento da política ambiental do estado, por meio do critério da proporção que cada município detenha do total da área 
das Unidades de Conservação.

A sistemática do ICMS Ecológico em Rondônia possui certa semelhança com a do Paraná, diferenciando-se quanto às medidas que envolvem a questão do cálculo, por considerar, apenas, variáveis quantitativas e não a qualidade das Unidades de Conservação. Este é um ponto falho, que precisa ser solucionado para se conseguir atingir as metas que estão por trás deste tipo de imposto.

Ressalta-se, porém, que em Rondônia, os municípios que tenham as suas Unidades de Conservação invadidas ou exploradas ilegalmente, gerando danos consideráveis ao meio ambiente, terão diminuição na parcela que recebem do ICMS Ecológico. O valor reduzido será repartido entre os municípios que estiverem com suas Unidades de Conservação respeitando a legislação ambiental.

O acompanhamento do nível de agressão verificada e explorações ilegais é realizado pelo órgão de gerenciamento, em conjunto com outras instituições. $\mathrm{O}$ controle é possível por meio de um sistema de cadastramento das Unidades de Conservação municipais, estaduais e federais.

O mesmo é presenciado no Paraná, porém, a redução na parcela só pode se proceder por meio de atos normativos complementares.

A Tabela 7 apresenta os percentuais de participação na cota do ICMS que determinados municípios têm direito a receber, após a criação do ICMS Ecológico no Estado de Rondônia. 
Tabela 7- Índice de participação na cota do ICMS dos municípios de Rondônia beneficiados com o ICMS Ecológico.

\begin{tabular}{l|c|c|c}
\hline Município & $\begin{array}{c}\text { Percentual de } \\
\text { participação antes do } \\
\text { ICMS Ecológico }\end{array}$ & $\begin{array}{c}\text { Percentual de } \\
\text { participação após a } \\
\text { criação do ICMS } \\
\text { Ecológico }\end{array}$ & $\begin{array}{c}\text { Aumento nos índices } \\
\text { de participação nos } \\
\text { municípios (\%) }\end{array}$ \\
\hline Jamari & 0,3509 & 0,5708 & 62,67 \\
\hline Costa Marques & 0,8589 & 1,3550 & 57,76 \\
\hline Guajará Mirim & 1,1948 & 1,8076 & 51,29 \\
\hline Monte Negro & 0,8323 & 1,1823 & 42,05 \\
\hline S. M. Guaporé & 0,5568 & 0,78 & 41,67 \\
\hline Gov. Jorge Teixeira & 0,4632 & 0,6302 & 36,05 \\
\hline Min. Adreazza & 0,9367 & 1,1817 & 26,16 \\
\hline Candeias & 1,4900 & 1,8408 & 23,54 \\
\hline Nova Mamoré & 0,5947 & 0,7204 & 20,49 \\
\hline Machadinho & 0,7790 & 0,9386 & 19,91 \\
\hline Alvorada d Oeste & 0,8362 & 1,0027 & 17,83 \\
\hline Cerejeira & 1,1735 & 1,3827 & 16,55 \\
\hline Seringueira & 0,4931 & 0,5747 & 14,59 \\
\hline Ji-Paraná & 9,5280 & 10,9176 & 13,20 \\
\hline Espigão D`Oeste & 1,5692 & 1,7764 & 10,23 \\
\hline Vilhena & 7,4372 & 8,1980 & 8,18 \\
\hline Vale do Anarú & 0,4181 & 0,4523 & 7,48 \\
\hline Rolim de Moura & 2,7886 & 2,9973 & 6,82 \\
\hline Jaru & 3,2733 & 3,49 & 1,16 \\
\hline Colorado D`Oeste & 1,1949 & 1,2379 & \\
\hline Santa Luzia & 1,3603 & & \\
\hline Fonte: SEFAZ & & & \\
\hline
\end{tabular}

Fonte: SEFAZ

Constata-se que 21 municípios, em um total de 52, beneficiam-se com o ICMS Ecológico. Os que apresentaram os maiores acréscimos nos índices foram Jamari, Costa Marques e Guajará Mirim. Dos municípios estudados na pesquisa estão presentes Ji-Paraná, Vilhena e Rolim de Moura.

Pelo pouco tempo de implantação deste instrumento, ainda é muito cedo para se avaliarem os resultados obtidos. Mesmo no caso do Paraná, que já possui o ICMS Ecológico desde 1992, também, não se pode concluir de forma definitiva sobre os benefícios obtidos, porém, observam-se alguns pontos consideráveis neste último estado: 
"aumento do número e da superfície das áreas protegidas, em especial das unidades de conservação; melhoria das unidades de conservação; popularização do debate sobre o tema, aprimoramento institucional, justiça fiscal; corredores de biodiversidade; geração de trabalho; possibilidade da reprodução da proposta em outros estados e despertar para a exploração de políticas tributárias" (Loreiro, 1998, p. 38). Na medida em que os mesmos efeitos surgirem em Rondônia, ter-se-á o ICMS como estímulo à gestão ambiental por parte dos municípios. 


\section{EVOLUÇÃO DO SETOR INDUSTRIAL MADEIREIRO EM RONDÔNIA}

Este capítulo procura analisar a evolução global do setor industrial madeireiro do Estado de Rondônia por meio das idéias de sustentabilidade e desenvolvimento sustentável discutidas no segundo capítulo. Além disso, retorna-se à questão já iniciada no capítulo 4 sobre a influência das políticas públicas na expansão do setor industrial madeireiro.

Deve-se salientar que a análise do setor industrial madeireiro do Estado de Rondônia será complementada no capítulo 6, que aborda, com certo grau de detalhamento, aspectos das condutas e desempenhos das empresas segundo as regiões e o tipo de atividade que executam dentro do setor em análise.

O presente capítulo é constituído por quatro itens. O primeiro item (5.1) descreve a evolução do setor industrial madeireiro na Amazônia Legal, enfocando, principalmente, a quantidade de empresas e seu tipo. O item 5.2 analisa as relações existentes entre exploração madeireira e desmatamento. $\mathrm{O}$ item 5.3 aborda os fatores determinantes da localização das empresas. E o item 5.4 procura analisar as experiências e possibilidades de sustentabilidade da exploração madeireira .

Os temas tratados neste capítulo são comuns a todos os estados que compõem a Amazônia Legal. Não obstante, procura-se ressaltar o Estado de Rondônia nos aspectos a serem examinados. 


\subsection{Evolução do setor industrial madeireiro na Amazônia Legal}

O setor industrial madeireiro é de grande importância econômica e social para os estados pertencentes à Amazônia Legal. No ano de 1987, esse setor gerou cerca de 250.000 empregos diretos e 800.000 empregos indiretos, e foi considerado como a segunda fonte geradora de recursos, perdendo apenas para o setor de mineração, em termos de arrecadação de Imposto sobre Circulação de Mercadorias (ICM) pelos estados (Terezo, 1990).

A partir do final da década de 60 , houve incremento no número de empresas pertencentes ao setor industrial madeireiro e aumento na extração de madeira na Amazônia Legal. Em 1953, existiam aproximadamente 89 serrarias na Amazônia Legal, com a seguinte distribuição por estados: 2 serrarias no Acre, 4 em Rondônia, 2 em Roraima, 1 no Amapá, 20 no Amazonas e 60 no Pará. Em 1981, constatou-se a existência de cerca de 1.600 serrarias e, em 1984, o número era da ordem de 3.000 delas na Amazônia (Browder, 1986; e, Terezo, 1990).

Analisando-se mais especificamente o Estado de Rondônia, durante a década de 80, verifica-se que o aumento no número de empresas ligadas ao setor industrial madeireiro foi bastante acentuado (Tabela 8). Houve grande crescimento das empresas de desdobramento de madeira. Das quatro serrarias existentes em 1953 passouse a 781 em 1987. 
Tabela 8- Número de empresas pertencentes ao setor industrial madeireiro de Rondônia - em 1980, 1982, 1985, 1987, 1994 e 1997

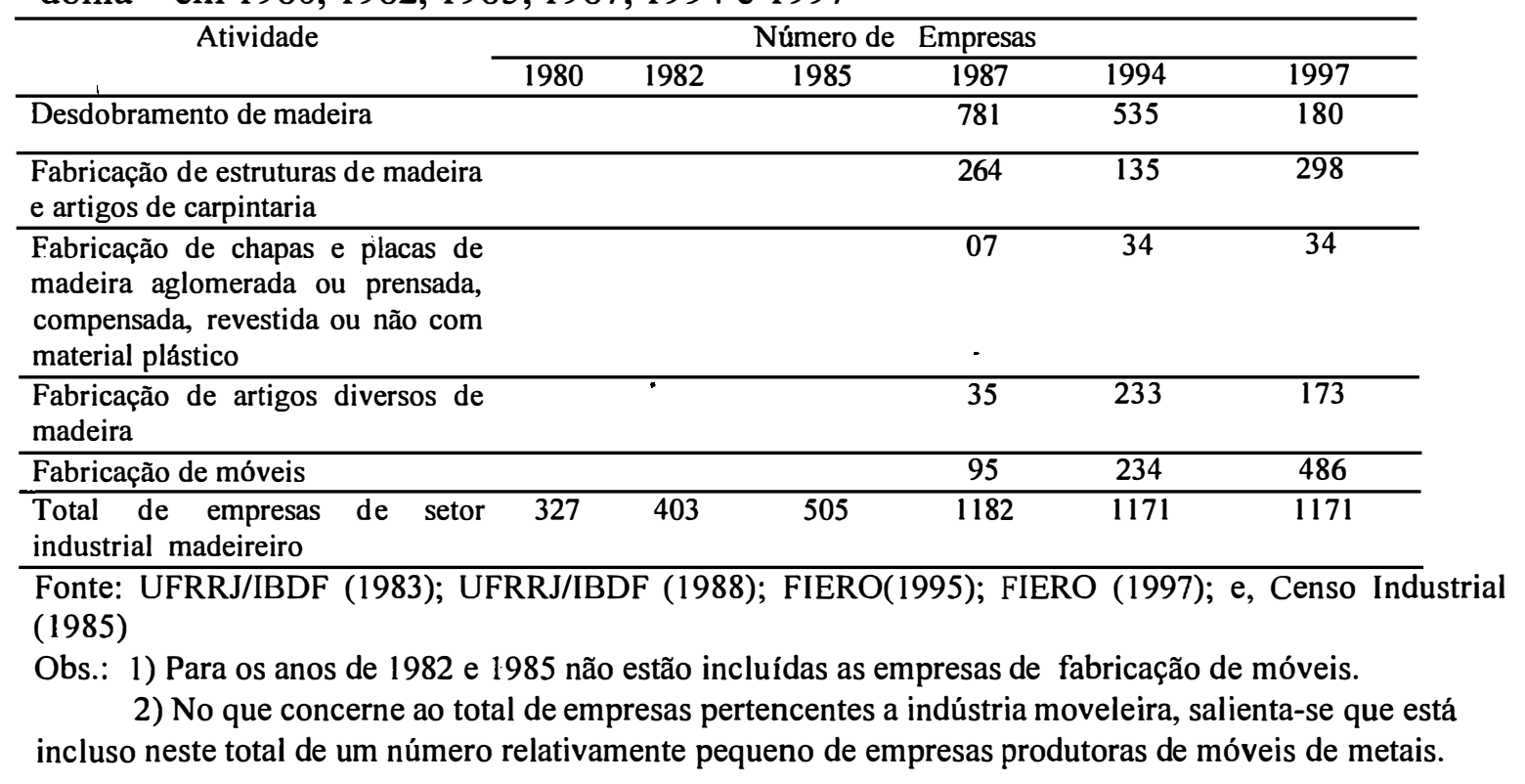

As causas da expansão do setor industrial madeireiro em Rondônia na década de 80 são similares às de outros estados da Amazônia.

Como já mencionado no item 4.3, a expansão da malha rodoviária foi um dos fatores que estava por trás do crescimento do setor industrial madeireiro na Amazônia. Até meados de 1960, a extensão das rodovias na Amazônia era extremamente pequena. Contudo, em 1988 havia, aproximadamente, $44 \mathrm{mil} \mathrm{km} \mathrm{de} \mathrm{rodovias} \mathrm{nessa}$ região. A construção de estradas cruzando a Amazônia era considerada um processo de integração nacional e possibilitava o desenvolvimento da região por meio da exploração dos recursos naturais, como as madeiras tropicais e os minérios (Barros \& Veríssimo, 1996, p.1; Kitamura, 1994; UHL \& Buschbacher, 1988, p.25; Browder, 1989; Yared \& Junior, 1989; e, Terezo, 1990).

Outro fator que intensificou a expansão do setor industrial madeireiro na Amazônia na década de 80 foram os créditos subsidiados e os incentivos fiscais concedidos a este tipo de atividade. Entre os anos de 1966 e 1983, a Superintendência do 
Desenvolvimento da Amazônia (SUDAM) liberou créditos e benefícios fiscais com o objetivo de instalação ou reformulação de 131 projetos madeireiros industriais, que implicaram, aproximadamente, US\$ 500 milhões em subsídios diretos. Estes significaram cerca de $36 \%$ do total de recursos aplicados pela SUDAM no seu programa de incentivos diretos através de impostos/créditos subsidiados com o intuito de atrair investimentos privados à Amazônia. A concessão de incentivos físcais e créditos subsidiados visando a exportação de produtos madeireiros influenciou o processo de desmatamento. $\mathrm{O}$ caso mais conhecido era a extração de mogno, que se dava de forma seletiva no Sul do Pará e ao longo da BR-364 em Rondônia (Kitamura, 1994; e, Browder, 1986, p. 8).

Como já exposto no item 4.3, a expansão da atividade madeireira na Amazônia também pode ser atribuída, em parte, à exaustão das florestas do Sul do País, especialmente das do Paraná, e ao esgotamento progressivo das florestas tropicais da Ásia, que eram responsáveis por $70 \%$ do comércio internacional de madeira (Veríssimo et al, 1996a, p.11; Lisboa, 1990, p.107; Fearnside, 1984, p.50; Lisboa, 1986; e, UFRRJ, 1983).

Não obstante, verifica-se, na década de 90 , a diminuição no número de empresas que compõem o setor industrial madeireiro do Estado de Rondônia, principalmente as ligadas ao desdobramento da madeira (ver Tabela 8)

O avanço do desmatamento e a falta de exploração sustentável têm feito as serrarias desativarem suas plantas e migrarem para outras regiões. Com isso, o número de serrárias em Rondônia diminuiu de 781 em 1987 para 535 em 1994 e 180 em 1997. De outro lado, tem havido grande crescimento de empresas moveleiras. Essas últimas têm maior flexibilidade para obter madeira em distâncias mais longas e optam pelo Estado de Rondônia por ser mais próximo de grandes centros consumidores (caso do Distrito Federal e estados do Sudeste) e bem próximo de grandes reservas florestais. Além desse fato, houve aumento da demanda interna por móveis produzidos no próprio 
estado.

O setor industrial madeireiro vem perdendo importância relativa em relação ao total de indústria do Estado de Rondônia, mas ainda continua sendo importante neste contexto. No ano de 1987, a participação do setor industrial madeireiro no total de estabelecimentos industriais era da ordem de 51,55\%. Em 1997, esta participação caiu para cerca de 31,19\% (FIERO, 1997). Isto é fruto da perda de dinamismo do setor industrial madeireiro, o que está, em parte, associado à falta de sustentabilidade da exploração dos recursos florestais.

\subsection{Relações entre exploração madeireira e desmatamento}

Antes da década de 60, a exploração madeireira na Amazônia era baseada em florestas de várzea. Com a construção de grandes rodovias (Belém-Brasília, Transamazônica, Cuiabá-Porto Velho-Rio Branco, Cuiabá-Santarém e Manaus-Boa Vista) observaram-se elevações significativas na produção, em decorrência da disponibilidade da madeira proveniente das florestas de terra firme, que até então eram pouco acessíveis (Terezo, 1990; e, Silva \& Ulh, 1992).

O crescimento da extração de madeira se deu de forma bastante intensa, tornando-se preocupante. Durante o ano de 1979 extraíram-se 8,4 milhões de metros cúbicos de madeira na Região Norte, o equivalente a $26,63 \%$ do total do Brasil; seis anos depois a retirada era da ordem de 20 milhões de metros cúbicos (46,16 \% do total do Brasil). No ano de 1992 , em torno de $71,23 \%$ da madeira produzida no País provinha da Região Norte (Tabela 5). Em 1993, a Amazônia foi responsável por cerca de 80,58\% da madeira em tora produzida no Brasil, não considerando a parte do Estado do Maranhão pertencente a Amazônia (IBGE, 1995). 
No Estado de Rondônia houve incremento na produção média de madeira serrada de cerca de $82,73 \%$, em 1980, quando comparada a 1970. Este crescimento fez com que muitas espécies de madeira de valor comercial se tornassem vulneráveis à extinção neste estado, como o mogno, o cedro, a cerejeira, entre outras (Lisboa, 1989; e, Lisboa, 1990).

O que deve ser ressaltado é que o nível de reposição de espécies de valor comercial é desprezível. Aproximadamente 200 espécies são extraídas para fins comerciais, porém, $60 \%$ da produção de madeira serrada e laminada no país é de apenas 10 espécies. Este tipo de exploração extremamente seletiva ocorre sobretudo nos estados de Rondônia ${ }^{7}$ e Pará, onde a extração madeireira parece ter atingido crescimento exponencial (Ulh \& Viera, 1991, p.110; Kitamura, 1994, p. 94; Barros \& Veríssimo, 1996, p.1; Lisboa, 1989; e, Lisboa, 1990).

A extração seletiva de madeira sem sua adequada reposição causa desequilíbrio no meio ambiente e perdas econômicas (Lisboa, 1990, p.103; e, Ulh \& Vieira, 1991, p.112). Este tipo de extração está gerando o fenômeno chamado de erosão genética, pois os indivíduos de espécies de madeiras nobres que ficam nas florestas possuem qualidade biológica inferior para a obtenção de material reprodutivo (Lisboa, 1989).

Dos estados pertencentes à Amazônia Legal, o de Rondônia é o que vem apresentado a mais rápida taxa de desmatamento. Entre os anos de 1983 e 1985, a área desmatada do estado elevou-se, em percentuais da área total, de 5,74\% para $11,38 \%$, respectivamente (Fearnside \& Salati, 1985; Fearnside, 1982; Fearnside, 1991; Fearnside, 1984; e, Mahar, 1990). Em 1996, o equivalente a 22,5\% da área total do estado estava desmatada (SEDAM, 1997).

${ }^{7}$ Em 1983, por exemplo, a quantidade de espécies aproveitadas em Rondônia para a obtenção de madeira não passava de 15. Este tipo de extração é preocupante por causar dois problemas já comprovados em diversas regiões tropicais: a perda de espécies e a erosão genética. 
É complicado saber qual é a contribuição isolada da extração madeireira no processo de desmatamento da Amazônia. As estimativas indicam contribuições entre 4 e 20\% (Kitamura, 1994; e, Serrão, 1995, p 57). Deve ser ressaltado, porém, que a extração madeireira auxilia na penewação e financiamento das demais atividades econômicas na região, devido ao seu pioneirismo na implantação de pastagens ou de outras atividades agrícolas.

A extração seletiva de madeira parece não ser uma das mais preocupantes causas do desmatamento na Amazônia, quando comparada às queimadas para a implantação de projetos agropecuários e ao alagamento de extensas áreas de florestas ocasionado por meio da construção de barragens para fins energéticos.

A preocupação com a extração seletiva de madeira, como já mencionado, diz respeito ao perigo de extinção das espécies que fornecem madeira de lei, devido à alta seletividade e à falta de um plano apropriado de exploração (Lisboa, 1990, p.107; e, Yared \& Junior, 1989). A matéria-prima utilizada pelo setor industrial madeireiro não é, em grande parte, proveniente do desmatamento por uso alternativo do solo, mas da exploração extrativa da floresta tropical amazônica, chamada de corte seletivo (Terezo, 1980).

Correa \& Correa (1990) salientam que o problema da exploração na terra firme é o esgotamento do recurso florestal no longo prazo, pelo fato de o interesse inicial das empresas não ser o produto florestal, mas a pecuária ou a agricultura. Portanto, a atividade madeireira é uma fase na consolidação do projeto, não havendo, então, interesse na aplicação de técnicas de manejo ou silviculturais que assegurem o suprimento de matéria-prima florestal no futuro. 


\subsection{Fatores determinantes da localização das empresas}

As empresas madeireiras que realizam a exploração seletiva, principalmente as serrarias, têm apresentado, na maior parte das vezes, um comportamento itinerante, movendo-se para novas áreas à procura de madeira de valor comercial. Nesse procedimento, onde o retorno econômico imediato é o fator primordial, existe a perda de sustentabilidade da atividade devido à exaustão do recurso florestal (Yared \& Junior, 1989).

O fator primordial que influenciou e ainda está por trás do decréscimo recente no número de empresas de desdobro de madeira (ver dados da Tabela 8) é a escassez de certos recursos florestais, que começa a ser sentida por estas empresas. Estas possuem duas alternativas: a desativação da empresa, principalmente pelo aumento no custo de transporte na busca de matéria-prima em regiões mais distantes; ou a migração de empresas para outras áreas dentro do estado, onde não existe o problema de escassez ${ }^{8}$.

Sobre a migração de empresas dentro do estado, as regiões que possuíam espécies de maior valor comercial (mogno e cerejeira) eram os municípios de Pimenta Bueno e Cacoal, sendo o total de empresas verificado nestas regiões, no ano de 1982, de 60 e 96 unidades industriais, respectivamente. Estes valores passam para 36 e 27 unidades para os mesmos municípios, no ano de 1994. Os números mostram o decréscimo no total de empresas nestas regiões, o qual está relacionado, em grande parte, à redução da disponibilidade da espécie mogno.

A produção de mogno em tora no Estado de Rondônia foi da ordem de $180.000 \mathrm{~m}^{3}$ no ano de 1989 , caindo para $80.000 \mathrm{~m}^{3}$ em 1992 . Quanto ao número de empresas que comercializam a espécie mogno no estado, em 1989 havia 350 e, em 1992,

\footnotetext{
${ }^{8}$ No Capitulo 6, estes dois pontos são tratados mais minuciosamente, a partir das repostas obtidas na pesquisa de campo realizada no Estado de Rondônia.
} 
88 unidades. Por outro lado, as empresas estão utilizando outros tipos de espécies. Este fato é constatado pela concentração de empresas processadoras da madeira em regiões nas quais não predominam as espécies mogno e cerejeira como, por exemplo, Porto Velho, que apresentava 31 dessas empresas em 1982 e em 1994 um total de 93 unidades. Outro fator que influencia a concentração de empresas do setor industrial madeireiro neste município e também no de Ariquemes é a proximidade destes de reservas extrativistas, cujo recurso florestal é extraído, na maior parte das vezes, ilegalmente?

O município de Ji-Paraná até o ano de 1978 era o maior produtor de madeira serrada dentro do estado, indicando uma produção de $29.381 \mathrm{~m}^{3}$. De acordo com um levantamento no ano de 1983, sua posição caiu para quarto lugar, com uma produção de $29.117 \mathrm{~m}^{3}$. A justificativa que está por trás da perda de posição é o crescimento acelerado de extração madeireira, que exauriu as florestas remanescentes da região. No ano de 1983, as serrarias de Ji-Paraná já utilizavam madeiras em toras de outros municípios.

O problema de escassez também já é sentido em outros estados da Amazônia. A espécie virola está prestes a chegar à exaustão no Estado do Pará. Segundo IBAMA/FUNATURA (1996), a região de Ilhas, neste estado, já foi responsável por mais de $70 \%$ do total de madeiras exploradas desta espécie. Devido à superexploração, porém, os madeireiros já temem a sua extinção. O município de Breves, há aproximadamente 15 anos, abastecia com sua produção todo o setor industrial madeireiro da sua região. Hoje, praticamente inexiste a exploração madeireira neste município. Atualmente, as empresas

\footnotetext{
9 Para se ter uma idéia, há alguns anos existia a possibilidade de pagamento de uma taxa ao IBAMA (até 1989 era IBDF), por parte das empresas madeireiras, pela utilização dos recursos florestais. Os recursos obtidos teriam que ser canalizados para projetos de reflorestamento ou manejo florestal. Este órgão, porém, não conseguia obter, muitas vezes, tal arrecadação pelo fato de as madeireiras agirem clandestinamente. Acredita-se que pelo menos a metade da atividade madeireira seja realizada de forma clandestina na Amazônia. No Estado de Rondônia, por exemplo, no ano de 1977, o número de serrarias registradas no IBDF era da ordem de 108 unidades. Contudo, através de fiscalizações realizadas ao longo da BR-364 (Cuiabá-Porto Velho) foram localizadas 60 serrarias clandestinas. Nos dias de hoje, ainda há possibilidade de pagamento da taxa, porém para pessoa física ou jurídica que tenha um consumo anual inferior a $600 \mathrm{~m}^{3} /$ ano (seiscentos metros cúbicos de toras por ano).
} 
industriais madeireiras adquirem a matéria-prima de outros municípios. Observa-se, atualmente, um deslocamento da "fronteira madeireira" para outros municípios dentro do Estado do Pará, como Afuá e Anajás, sendo que o segundo corresponderia ao estágio final da exploração baseada na espécie virola, no Pará.

Do exposto acima, constata-se que, na Amazônia, a exploração madeireira na terra firme está levando à escassez de algumas espécies mais valiosas como cerejeira (Amburana acreana) e mogno (Swietenia macrophylla), e nas florestas inundadas de várzea a exploração madeireira está ocasionando o declínio de espécies de valor comercial como ucuúba (Virola spp). E simultaneamente a esse esgotamento, nota-se o caráter itinerante das empresas de desdobramento de madeira. Isto, claramente, não é um desenvolvimento sustentável, pois a produção atual está impedindo as gerações futuras de atenderem a seus consumos com os recursos naturais remanescentes.

A sobrevivência do setor industrial madeireiro em Rondônia resultará, em grande parte, da intensidade do desmatamento no estado ${ }^{10}$. Este último pode ser controlado por meio de um trabalho conjunto entre alguns órgãos oficiais, com o intuito de uma melhor utilização da terra e racionalização da exploração (UFRRJ/IBDF, 1983, p.12).

\subsection{Experiências e possibilidades da exploração madeireira sustentável em Rondônia}

A atividade florestal na Amazônia, ao mesmo tempo que é uma fonte de geração de divisas e benefícios sócio-econômicos, gera preocupação pelo fato de a

\footnotetext{
${ }^{10}$ A tendência ao aumento do desmatamento da Região Amazônica, contudo, não deve ser descartada, em decorrência, principalmente, da diminuição das espécies madeireiras das florestas úmidas do Sudeste da Ásia (FEARNSIDE, 1994). Na verdade, o que ocorre é que com a exaustão das florestas asiáticas verifica-
} 
exploração estar sendo realizada de forma irracional, causando impactos significativos sobre a floresta. Ou seja, acaba implicando perdas severas no dossel da mata, na elevação da tendência a incêndios e na invasão de cipós e gramíneas (Uhl \& Vieira, 1991; Lisboa et al, 1991; Lisboa, 1986; Uhl et al, 1996, p.145; Kitamura, 1994; e, Silva \& Uhl, 1992).

Em estudo realizado nas proximidades de Tailândia (PA), ao longo da rodovia PA-150, na Amazônia Oriental, constatou-se que a retirada de uma árvore danifica, em média, um total de 26 outras árvores. Estes danos da exploração também podem ser classificados por tipos. O estudo mostra que $46 \%$ das árvores danificadas foram cortadas, para a abertura de estradas de exploração e zonas de acostamento; $41 \%$ foram quebradas; $8 \%$ arrancadas; e $5 \%$ foram rasgadas. Estas árvores localizavam-se nas clareiras formadas pela derrubada das árvores de valor comercial no processo de exploração, prejudicando a regeneração das espécies (Veríssimo et al, 1996a, p.32; Veríssimo et al, 1996b, p. 63; Lisboa, 1990). Acredita-se que fenômeno similar ocorre na exploração das florestas de Rondônia.

De acordo com um estudo realizado por Veríssimo et al (1996b) em determinada região do Município de Paragominas, concluiu-se que a adoção do manejo florestal é uma condição sine qua non para a sobrevivência do setor madeireiro" e das florestas de Paragominas (PA). Caso este fato ocorra, há grandes probabilidades da manutenção da atividade madeireira a longo prazo na região de Paragominas (Serrão, 1995, p.72; Veríssimo et al, 1996b, p.73; e, Uhl \& Vieira, 1991).

A suposição de que não há conhecimento científico para o manejo das florestas é sustentada por muitas pessoas. Contudo, este fato não é verdadeiro. A sua não implantação se deve, muitas vezes, a razões essencialmente políticas e sociais. O sucesso do manejo de florestas tropicais é observado em diversos países, tendo como exemplo o

"Se o caráter predatório da exploração continuar, as florestas da região desaparecerão nas próximas 
caso da Malásia Peninsular, que foi explorada há 50 anos e nos últimos anos vem sendo reexplorada. Isto é uma comprovação de que a sustentabilidade pode ser alcançada, mas depende de uma extração disciplinada e do compromisso do extrator pela manutenção da produtividade da floresta. Não basta, porém, apenas aplicar a técnica de manejo, mas, sim, combinar este tipo de conhecimento com: 1) regulamentos que determinem onde a exploração madeireira deve ser realizada ou não (zoneamento florestal); e, 2) a efetiva aplicação da legislação florestal (Silva \& Uhl, 1992, p.158; Uhl et al, 1996, p. 158; Ulh \& Vieira, 1991, p. 115; Pandolfo, 1995; Kitamura, 1995).

Através de um estudo realizado na região de Paragominas chegou-se à conclusão, por meio de alguns dados econômicos, de que a adoção do manejo florestal, por parte das empresas madeireiras, não impede que estas continuem obtendo lucros (Uhl et al, 1992, P. 20). O apêndice B descreve uma dessas experiências de exploração florestal sustentável.

Com relação aos poucos programas de reflorestamento na Amazônia, os existentes são orientados mais à quantidade do que à diversidade de madeiras. Nos dias de hoje, as plantações de espécies são destinadas a atender à demanda de celulose, como as plantações de gmelina, eucalyptus e pinus, no Projeto Jari. O incentivo ao reflorestamento de espécies de valor comercial deve ser uma das principais prioridades dos órgãos oficiais ligados ao meio ambiente (Lisboa, 1986, p.82; Yared \& Junior, 1989). No Estado de Rondônia, observa-se que alguns empresários - individualmente e/ou por meio de associações e/ou cooperativas - já realizam o reflorestamento e o manejo florestal.

$\mathrm{Na}$ pesquisa de campo, segundo informações dos entrevistados, constatou-se que no Estado de Rondônia existem empresas responsáveis pela realização do reflorestamento. $\mathrm{O}$ que se procede é que algumas empresas, que não possuem recursos suficientes para realizar tal procedimento, pagam uma taxa para outra empresa, 
que fica incumbida em realizar o reflorestamento. As empresas contratantes dos serviços são cadastradas no IBAMA. Uma afirmação que não pode ser feita é se realmente os reflorestamentos estão sendo efetivados. O tipo de serviço também é válido para manejo florestal, porém, com um nível de freqüência bem menor. Alguns exemplos de empresas que prestam estes serviços são: Reflorestadora Marupá (Porto Velho); Frey Rondônia Florestal S/A (Ariquemes); Plantar Reflorestadora LTDA (Cacoal); Instituto Estadual Floresta Rondon (Pimenta Bueno); e, Agro-florestal Donadoni LTDA (Vilhena)

No caso do reflorestamento em Rondônia, as espécies mais utilizadas são: a teca, o freijó, o mogno, a caixeta e o cedro-rosa. Além destas, também se verificam os plantios de ipê, leiteira, pinus, açaí, faveira, itaúba, marupá, bandarra, cerejeira, samaúma, sucupira, entre outras.

A área total reflorestada neste estado perfaz um total de 12.402 ha, dos quais 11.517.224 árvores das espécies mencionadas já foram plantadas (Tabelas 9 e 10). A data para os primeiros cortes está prevista para 1999 (FIERO, 1997).

Tabela 9- Projetos de reflorestamento no Estado de Rondônia

\begin{tabular}{lcc}
\hline \multicolumn{1}{c}{ Projetos } & No- de Mudas Distribuídas & Hectares Reflorestados \\
\hline FUNDAGRO & 881.437 & 2.004 \\
PAIC & 848.197 & 1.501 \\
Projeto de Reflorestamento & 8.408 .442 & 6.620 \\
Levantamento Circunstancial & 1.379 .148 & 2.277 \\
\hline Total & 11.517 .224 & 12.402 \\
\hline Fonte: FIERO (1997), citando SEPLAN/PLANAFLORO
\end{tabular}

Fonte: FIERO (1997), citando SEPLAN/PLANAFLORO

Tabela 10- Número de mudas distribuídas pelas Instituições de Fomento do reflorestamento no Estado de Rondônia

\begin{tabular}{lcc}
\hline \multicolumn{1}{c}{ Instituições } & № de Mudas Distribuídas & Hectares Reflorestados \\
\hline PLANAFLORO & 1.729 .634 & 3.505 \\
IBAMA & 9.787 .590 & 8.897 \\
\hline TOTAL & 11.517 .224 & 12.402 \\
\hline
\end{tabular}

Fonte: FIERO (1997), citando SEPLAN/PLANAFLORO 


\section{ESTRATÉGIAS DE ABASTECIMENTO ADOTADAS PELAS EMPRESAS INDUSTRIAIS PROCESSADORAS DA MADEIRA}

Para complementar a análise do capítulo anterior, no trabalho em questão foi realizada uma pesquisa de campo, através da aplicação de questionários, com o intuito de verificar diferenças ou semelhanças na conduta das empresas, quanto ao seu abastecimento de madeira, e no desempenho das empresas segundo a região de Rondônia em que se localizam e o ramo industrial a que pertencem. No item 6.1 são caracterizadas as regiões em estudo, enfocando as diferenças de desempenho segundo o grupo de empresas e sua localização. No item 6.2 discute-se o processo de troca e migração de proprietários das empresas; e no item 6.3, o problema de escassez de certas espécies madeireiras. Finalmente, no item 6.4, é avaliada a preocupação com questões ambientais por parte das empresas do setor industrial madeireiro de Rondônia.

Segundo o paradigma estrutura-conduta-desempenho, a estrutura de uma indústria ou mercado determina a conduta das empresas que, por sua vez, determina o desempenho das mesmas. Também há a possibilidade de esta relação de determinação ser verificada no sentido oposto. Além disso, a estrutura afeta e é afetada pelas condições básicas de oferta e demanda, ocorrendo o mesmo processo no caso da relação da conduta com as políticas governamentais, ou seja, a conduta influencia e é influenciada pelas políticas governamentais (Carlton \& Perloff, 1991).

$\mathrm{Na}$ presente pesquisa são analisados alguns elementos da conduta, como,

por exemplo, as atitudes tomadas pelas empresas perante o problema de escassez de 
matéria-prima; e, o desempenho destas com respeito às suas decisões de conduta. Outros dois pontos enfocados são: o desempenho influenciando a conduta no que diz respeito ao lucro (principalmente no curto prazo) e a relação das políticas governamentais, em especial a política regulatória, com a conduta e o desempenho das empresas pertencentes ao setor industrial madeireiro do Estado de Rondônia.

\section{1- Caracterização da região em estudo}

O capítulo 4 tratou das políticas públicas voltadas, mais especificamente, para o Estado de Rondônia, que foram responsáveis pelo intenso fluxo migratório em direção a este Estado e pela conseqüente ampliação de certos setores, até então incipientes, como é o caso do setor industrial madeireiro.

Neste item, analisam-se os resultados obtidos na pesquisa realizada nas empresas pertencentes a este setor. Na figura 1 (no capítulo 3) estão destacados os sete municípios escolhidos, que compõem dois pólos. Seis desses municípios são cortados pela BR-364 (principal eixo de acesso dos migrantes que chegam ao estado por via rodoviária), com exceção de Rolim de Moura. Não obstante, este município foi alvo de interesse por parte de empresas madeireiras, por predominar em suas áreas o mogno.

Em meados da década de 80 , havia grande concentração de empresas pertencentes ao setor industrial madeireiro no Sudoeste do estado, entre os municípios de Vilhena e Ji-Paraná. Mais especificamente, em Vilhena, Pimenta Bueno e Cacoal. O município de Rolim de Moura estava começando a se destacar em termos de concentração de empresas. As razões primordiais para o aumento do número de empresas nestes municípios eram a abundância de espécies florestais de grande valor comercial - com especial destaque para o mogno e cerejeira - e o melhor escoamento da produção, 
auxiliado pela $\mathrm{BR}-364$.

O setor industrial madeireiro foi responsável pelo desenvolvimento dos Municípios de Vilhena, Rolim de Moura, Pimenta Bueno, além de outros. A economia da cidade de Rolim de Moura era baseada na indústria madeireira.

No que diz respeito à comercialização, Vilhena se destacava por ser a primeira cidade do estado situada ao longo da BR-364, principal via de acesso para o escoamento dos produtos madeireiros para os mercados internos e externos.

Outro ponto a ser mencionado é que as empresas de maior porte situavamse em regiões com melhor infra-estrutura, vinculando este fator à maior abundância de matéria-prima. Os municípios que se destacavam em termos de empresas de grande porte eram Vilhena e Pimenta Bueno (localizados no pólo 1). Atualmente, ainda predominam grandes empresas nestes municípios, como constatado na pesquisa de campo.

O município de Rolim de Moura, por ser rico na espécie mogno, começou a apresentar um crescimento considerável, especialmente, em meados da década de 80 , no processamento industrial do mogno. A utilização dos recursos florestais foi bastante intensa, neste município, segundo a SEDAM (1997). No ano de 1993, a área desmatada do município era de $87,17 \%$ de sua superfície; extrapolando, isto quer dizer que a maior parte das propriedades rurais deste município já possui um percentual desmatado maior que o permitido por lei.

Nos municípios de Ji-Paraná, Ariquemes e Porto Velho (que compõem o pólo 2) há pouca predominância de mogno e cerejeira. Prevalece, nestas áreas, a espécie castanheira. 


\subsection{1 processo de crescimento desigual da atividade industrial madeireira nos pólos}

A análise do número de empresas de processamento mecânico nos pólos 1 e 2, no período compreendido entre 1985 e 1994, permite diferenciá-los em áreas de expansão mais tardia e mais recente, respectivamente, do setor industrial madeireiro. No primeiro pólo, houve decréscimo no número de empresas de processamento mecânico da madeira entre 1985 e 1994 (ver Tabela 11). Existiam 296 empresas em 1985, passando para 145 em 1994. Um dos fatores associados à diminuição desse tipo de empresa foi o aumento da distância na obtenção de madeiras de maior valor comercial, cujo acesso parecia, a priori, ilimitado por parte dos proprietários de empresas.

Tabela 11- Empresas de processamento mecânico de madeiras e moveleiras em alguns municípios de Rondônia nos anos de 1985, 1994 e 1997

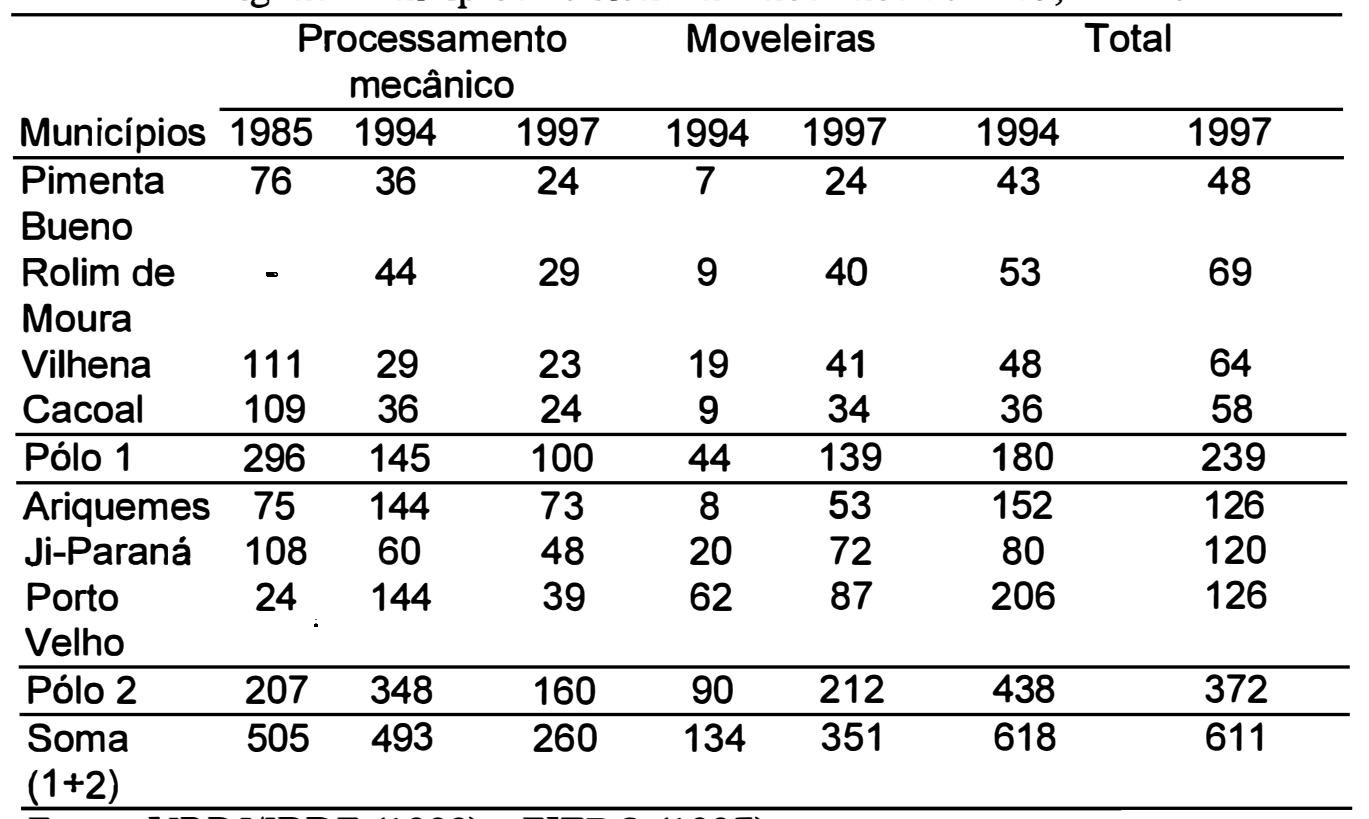

Fonte: URRJ/IBDF (1988) e FIERO (1997)

Obs.: No ano de 1985 não estão incluídas as moveleiras. 
Com a escassez de madeiras de maior valor comercial e o conseqüente aumento da distância na obtenção de tais madeiras, iniciou-se uma fase de fechamento de várias empresas e transferência de proprietários para outras regiões. Aliado a isto está a conclusão da pavimentação da BR-364 em setembro de 1984 que, como foi observado no item 4.3, intensificou ainda mais a migração em direção ao Estado de Rondônia, facilitando o acesso para outros municípios do estado que eram mais distantes do CentroSul.

Os municípios situados no pólo 2 tiveram, com a conclusão da pavimentação da BR-364, maior facilidade de acesso ao Centro-Sul, o que, em parte, levou à expansão da atividade industrial processadora da madeira nestes municípios. Com isso, observou-se aumento de $68,12 \%$ (Tabela 11) no número de empresas de processamento mecânico da madeira nos municípios deste pólo entre 1985 e 1994.

Há que ressaltar, porém, que, entre 1994 e 1997, presenciou-se a diminuição no número de empresas de processamento mecânico nos dois pólos. A razão por trás deste aspecto está na escassez de determinadas madeiras que foi ocasionada por uma expansão desordenada do setor industrial madeireiro e que não esteve preocupada com a exploração sustentável dos recursos florestais nativos.

As empresas instaladas eram de pequeno, médio e grande portes. Os fatores que facilitavam a criação de uma grande quantidade de empresas com tamanha dispersão eram a abundância de madeira de qualquer espécie, inclusive as de maior valor comercial, que eram obtidas a distâncias bastante próximas da localização das empresas; e, a quase inexistência de barreiras à entrada nesta atividade. Com a escassez de madeiras de maior valor comercial e pelas características intrínsecas do setor industrial madeireiro, de obtenção de lucro a curto prazo, presenciou-se uma queda significativa no número de empresas de processamento mecânico da madeira.

Com a dificuldade de obtenção de certas madeiras em determinadas áreas 
do estado e as facilidades de penetração, auxiliadas pelo término da pavimentação da BR364, durante o POLONOROESTE, observou-se uma mudança no quadro de localização de empresas de processamento mecânico da madeira, constatadas nos pólos 1 e 2 .

Ao realizar-se a análise por município, verifica-se que as empresas situavam-se, em 1985, principalmente em Vilhena, Cacoal, Pimenta Bueno e Ji-Paraná (ver Tabela 11), os quais se situam mais próximos do Centro-Sul. No Município de Rolim de Moura, vizinho aos demais mas não cortado pela BR-364, a expansão madeireira tornou-se mais intensa após 1985, apresentando um ciclo bastante curto, pois a espécie predominante em suas áreas era o mogno, sendo este extraído de forma extremamente seletiva e predatória, o que ocasionou uma dificuldade cada vez maior em sua obtenção. Ji-Paraná, incluído no pólo 2 e localizado entre Ariquemes e Cacoal (este último no pólo 1), portanto com características intermediárias, foi um município que apresentou um crescimento considerável de empresas de processamento mecânico da madeira, diminuindo em quantidade no ano de 1994. Esta redução, porém, não foi tão intensa quando se compara com os municípios de Vilhena, Pimenta Bueno e Rolim de Moura (todos do pólo 1).

Nos Municípios de Porto Velho e Ariquemes (do pólo 2) observaram-se incrementos expressivos de empresas, entre 1985 e 1994. Porto Velho possuía um total de 24 empresas de processamento mecânico em 1985 e aumentou este número para 144 empresas em 1994. Constatou-se, também, crescimento considerável em Ariquemes (de 75 para 144 entre 1985 e 1994, respectivamente).

Nó período de 1994 e 1997 houve redução de empresas de processamento mecânico de madeira em todos os municípios analisados. As empresas de desdobro de madeira, como demonstrado na Tabela 8 (capítulo 5), foram as principais responsáveis por esta diminuição abrupta de empresas do segmento madeireiro.

Outro ponto que merece destaque, especialmente entre os anos de 1994 e 
1997, foi o incremento de empresas ligadas à indústria moveleira nos dois pólos. No pólo 1 houve maior aumento relativo deste tipo de empresa, quando comparado ao pólo 2 . O número de empresas moveleiras do pólo 1 cresceu 216\% entre 1994 e 1997 (passando de 44 para 139 empresas, respectivamente) e 136\% no pólo 2 (existiam 90 empresas moveleiras neste pólo em 1994 e 212 em 1997).

Antes de 1994, grande parte dos móveis utilizados pela população do estado era proveniente do Sul do País. A grande expansão da indústria moveleira no estado a partir deste ano se explica pela: maior flexibilidade que as empresas moveleiras de Rondônia possuem na obtenção de madeira; utilização de outras espécies arbóreas (como as chamadas madeiras brancas) que, de certa forma, diminui, o preço final do móvel; e, maior aceitação, por parte da população local, dos móveis produzidos internamente.

O maior crescimento relativo da indústria moveleira no primeiro pólo pode estar relacionado com a sua maior proximidade ao Centro-Sul do País, atraindo os investimentos direcionados à produção de móveis que se destinam a abastecer outras regiões do Brasil, fato que é constatado por meio da maior participação das empresas pertencentes a este pólo no atendimento às "outras regiões" (como será visto à frente).

Ressalta-se, poréni, que a presença de empresas moveleiras é maior no pólo 2, sendo isto justificado pela maior concentração da população do estado neste pólo, já que a indústria moveleira do estado é mais voltada ao mercado interno. Neste pólo, houve um incremento significativo no número de empresas moveleiras no Município de Ariquemes, o que pode estar relacionado ao "pólo moveleiro" que está sendo implantado no Município. Neste "pólo moveleiro" haverá uma serraria comunitária. Pretende-se direcionar parte da produção para fora do estado e para outros países. A madeira será fornecida a preço de custo. Para ingressar no pólo moveleiro, os associados pagam uma taxa "simbólica" mensal. Em Ji-Paraná o acréscimo no número de empresas moveleiras também foi considerável. Em 1994 este município possuía 20 empresas moveleiras, 
aumentando para 72 empresas em 1997.

Quando se perguntou às empresas do estado sobre o desejo de se diversificar a produção, constatou-se que no pólo 1 há maior interesse das empresas de processamento mecânico da madeira nessa diversificação, com de $23,81 \%$ das empresas desejando realizar a diversificação (Tabela 12). No pólo 2, o interesse maior pela diversificação foi por parte das empresas moveleiras (38\%). De modo geral, o interesse das empresas do setor industrial madeireiro em diversificar a produção é pequeno.

Tabela 12- Percentual de empresas do setor industrial madeireiro de Rondônia que desejam diversificar a produção - situação em 1997

\begin{tabular}{c|c|c}
\hline Tipo de empresa & Pólo 1 & Pólo 2 \\
\hline $\begin{array}{c}\text { Processamento mecânico da } \\
\text { madeira }\end{array}$ & 23,81 & 18,18 \\
\hline Moveleira & & 38,1 \\
\hline Total & 7,14 & 29,33 \\
\hline
\end{tabular}

Fonte: dados da pesquisa de campo

O quadro acima descrito se repete para a questão que diz respeito ao plano futuro de ampliação da empresa. As empresas de processamento mecânico da madeira do pólo 1 tiveram uma maior sinalização para ampliação da empresa $(33,33 \%)$. Não obstante, as moveleiras pertencentes ao pólo 2 apresentam maiores perspectivas de ampliação da empresa (Tabela 13).

Tabela 13- Percentual de empresas do setor industrial madeireiro de Rondônia que possuem plano futuro de ampliação da empresa - situação em 1997

\begin{tabular}{c|c|c}
\hline Tipo de empresa & Pólo 1 & Pólo 2 \\
\hline $\begin{array}{c}\text { Processamento mecânico } \\
\text { da madeira }\end{array}$ & 33,33 & 30,3 \\
\hline Moveleira & 28,57 & 59,52 \\
\hline Total & 30,61 & 46,67 \\
\hline
\end{tabular}

Fonte: dados da pesquisa de campo 
Ao se analisar a produção média das empresas de processamento mecânico da madeira nos dois pólos, observa-se que no pólo 1 esta variável é maior (Figura 2). Constata-se, por meio da produção média e pelo número médio de empregados (será comprovado posteriormente), que as empresas de processamento mecânico de madeira apresentam um porte maior que as situadas no pólo 2. Este fato tem associação com a localização destas empresas; ou seja, as empresas, atualmente existentes no pólo 1 , possuem determinadas características que as viabilizam continuar sendo localizadas em uma região que apresenta certa escassez de madeira de maior valor comercial.

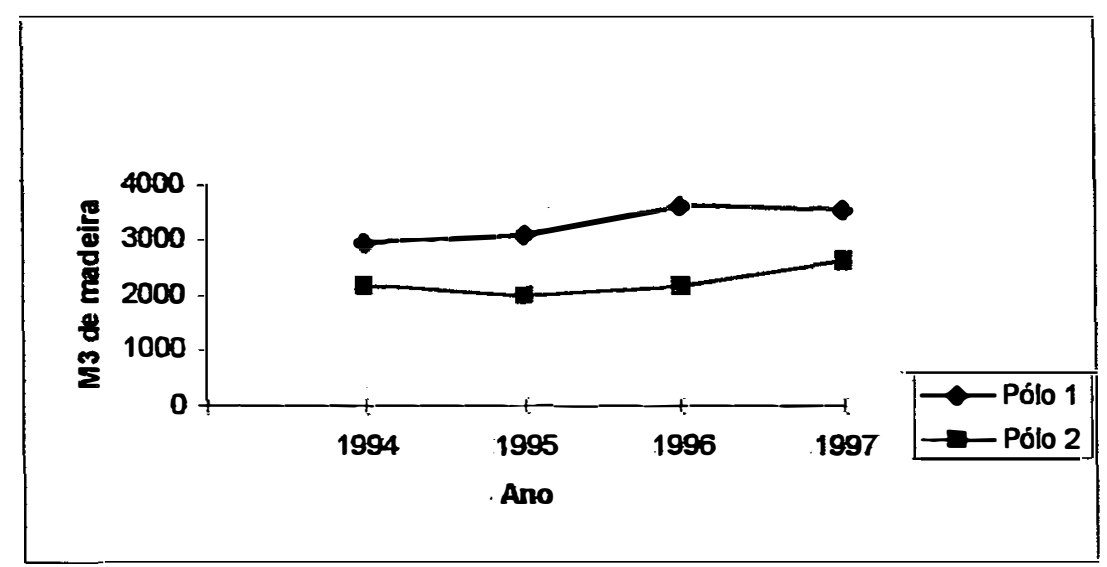

Figura 2- Produção média das empresas de processamento mecânico da madeira dos pólos 1 e 2 entre os anos de 1994 e 1997

Ressalta-se, porém, que em termos de produtividade o comportamento das empresas localizadas no pólo 1 foi relativamente estável e abaixo dos observados nas empresas pertencentes ao pólo 2 . 


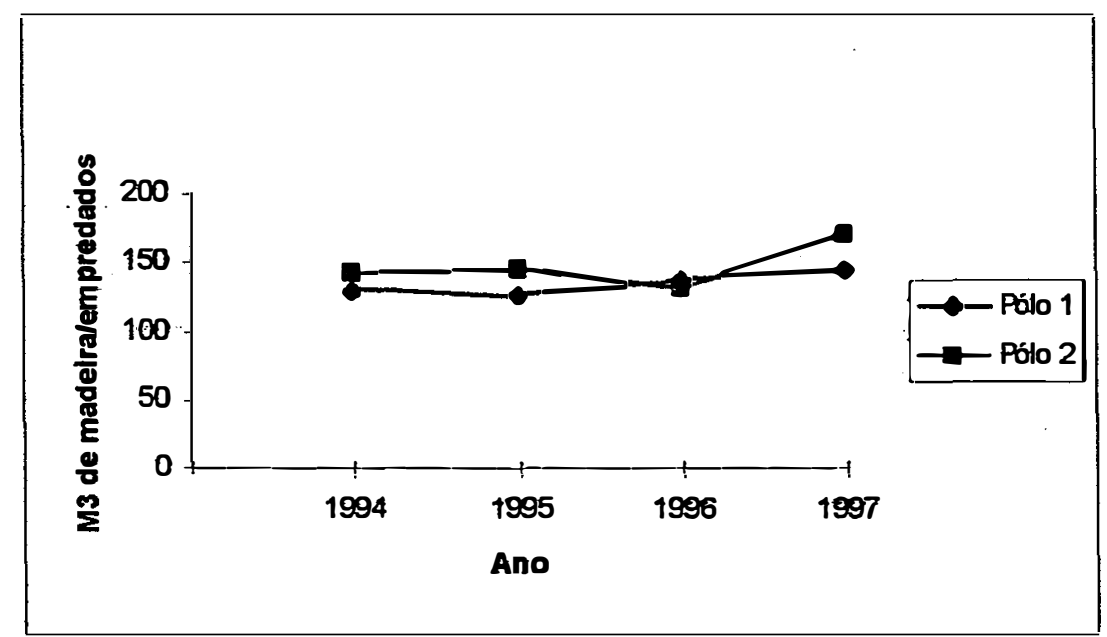

Figura 3- Produtividade média das empresas de processamento mecânico da madeira dos pólos 1 e 2 entre os anos de 1994 e 1997

No que se refere ao atendimento aos mercados por parte das empresas, as de processamento mecânico, nas décadas de 70 e 80, direcionavam grande parcela da produção para fora de Rondônia e, como jả mencionädo, havia pouca presença de empresas moveleiras, sendo o mercado local atendido por empresas do Sul do País. Com o problema da escassez de madeira, houve uma reversão neste quadro. Essa escassez gerou uma busca cada vez mais distante e um aumento no custo de obtenção de madeiras de maior valor comercial. A sölução encontrada por parte de muitas empresas, tanto do pólo 1 quanto do 2, foi a de utilização de outras espécies madeireiras, que possuem um valor mais baixo, como: maracatiara, angelim, ipê, jatobá, cumaru, samaúma, caxeta, caucho, entre outras. Esta opção não compensa o custo de transportar madeiras para outras regiões, pois o custo do frete é, müitas vezes, semelhante ou até superior ao da madeira a ser transportada, tendo como altemativa o atendimento ao mercado local e estadual. Deve-se enfatizar, porém, que ainda é bastante significativa a presença de empresas de processamento mecânico da madeira ofertando seus produtos para fora do . Estado de Rondônia.

Segundo os dados da Tabela 14, em 1997, cerca de $43 \%$ das empresas de 
processamento mecânico de madeira do pólo 1 atendiam ao mercado local. No pólo 2, há um menor atendimento por parte das empresas ao mercado local. Dois aspectos que provavelmente estão por trás da maior participação das empresas do pólo 1 no atendimento ao mercado local é a questão do porte destas empresas, que é bem maior neste pólo, dando sustentação para grande parte destas empresas, além de suprir parte do mercado local, também, ofertar para outras regiões. O fato de as empresas localizadas neste pólo serem relativamente mais antigas também é relevante, pois implica já terem o seu mercado garantido.

Tabela 14- Percentual de atendimento aos mercados das empresas do setor industrial madeireiro de Rondônia - situação em 1997

\begin{tabular}{l|c|c|c|c|c|c|c|c|c|c}
\hline & \multicolumn{9}{|c|}{ Pólo 1 } & \multicolumn{5}{c}{ Pólo 2 } \\
\hline $\begin{array}{l}\text { Tipo de } \\
\text { empresa }\end{array}$ & Local & Estadual & AL & Outras Regiões & Exterior & Local & Estadual & AL & $\begin{array}{l}\text { Outras } \\
\text { Regiões }\end{array}$ & Exterior \\
\hline $\begin{array}{l}\text { Processamento } \\
\text { mecânico da } \\
\text { madeira }\end{array}$ & 42,86 & 28,57 & 0 & 80,96 & 28,57 & 27,27 & 18,18 & 3,03 & 81,82 & 12,12 \\
\hline Moveleira & 89,29 & 10,71 & 0 & 39,29 & 0 & 97,62 & 21,43 & 0 & 23,81 & 0 \\
\hline Total & 69,39 & 18,37 & 0 & 57,14 & 12,24 & 66,67 & 20 & 1,33 & 49,33 & 5,33 \\
\hline
\end{tabular}

Fonte: dados da pesquisa de campo

As empresas de processamento mecânico de madeira do pólo 1 também se destacam no atendimento ao mercado estadual, sendo o percentual de $28,57 \%$, quando comparado ao pólo 2 , que detém uma parcela de $18,18 \%$.

Ao se analisar o atendimento às outras regiões e ao exterior, observa-se que no primeiro houve uma maior freqüência das empresas do pólo 2 , de aproximadamente $81,82 \%$, porém, bastante próxima das do pólo 1 , de cerca de $80,96 \%$. Conclui-se, pela proximidade dos percentuais, que o atendimento às outras regiões é similar nos dois pólos. Deve-se enfatizar a preferência das empresas do pólo 2 ao atendimento voltado para fora do estado, em detrimento ao mercado local e estadual. Quanto ao atendimento ao exterior, também prevalece a maior participação das empresas do pólo 1, que além de ter relação 
com as questões acima citadas, pode estar vinculado ao maior tamanho dessas empresas.

No caso das empresas moveleiras, o atendimento nos dois pólos é mais voltado ao mercado local. As empresas do pólo 2 se dedicam relativamente mais ao atendimento ao mercado local $(97,62 \%)$, quando relacionadas às empresas do pólo 1 . Não obstante, $\mathrm{o}$ atendimento às outras regiões é relativamente mais pronunciado no pólo 1 , $\mathrm{o}$ que se deve a sua maior proximidade do Centro-Sul.

No global (considerando empresas de processamento mecânico e moveleiras em conjunto), o atendimento ao mercado local é relativamente um pouco maior nas empresas localizadas no pólo 1, devido a um número considerável de empresas de processamento mecânico e moveleiras suprirem ao mercado local. Ressalta-se, porém, que o atendimento ao Estado é um pouco maior no pólo 2 e o das outras regiões é maior no pólo 1, especialmente por ser um pólo mais antigo.

Em termos de número médio de empregados por empresas, verifica-se que ele é maior para as empresas de processamento mecânico da madeira (ver Tabela 15). No pólo 1, o valor médio é de 43 empregados, sendo bem maior quando contraposto ao pólo 2. A avaliação do porte das empresas foi realizada no início do atual capítulo, sendo o resultado obtido, neste caso, já esperado. Com o conhecimento prévio das características deste pólo 1, esperava-se, ao menos, que as empresas que sobreviveram nestas regiões possuíssem uma certa estrutura para obter matéria-prima em uma distância maior e continuar obtendo lucro, estando este ponto vinculado ao porte destas empresas. No caso das empresas moveleiras, o número médio de empregados é igual nos dois pólos, de cerca de 5 empregados. Por meio dos questionários constata-se que a grande maioria das empresas moveleiras no Estado de Rondônia é de pequeno porte, fator que justifica o empenho delas em destinarem-se mais ao atendimento do mercado local. 
Tabela 15- Tamanho meedio das empresas do setor industrial madeireiro - situação em 1997

\begin{tabular}{c|c|c}
\hline Tipo de empresa & Pólo 1 & Pólo 2 \\
\hline & $\begin{array}{c}\text { Número médio } \\
\text { de empregados }\end{array}$ & $\begin{array}{c}\text { Número médio de } \\
\text { empregados }\end{array}$ \\
\hline $\begin{array}{c}\text { Processamento } \\
\text { mecânico da } \\
\text { madeira }\end{array}$ & 43 & 20 \\
\hline Moveleira & 5 & 5 \\
\hline Total & 21 & 11 \\
\hline
\end{tabular}

Fonte: dados da pesquisa de campo

Os gráfico 3 e 4 mastram a evolução do número médio de trabalhadores, durante 4 anos, para as empresas de processamento mecânico da madeira e para as moveleiras. Nestes gráficos é perceptível que, no caso das empresas de processamento mecânico da madeira, há uma tendência de permanência das grandes empresas no pólo 1 ; enquanto, no pólo 2 , ocorre o contrário.

As empresas moveleiras apresentam comportamentos similares nos dois pólos. Ou seja, observa-se a expansão de pequenas empresas.

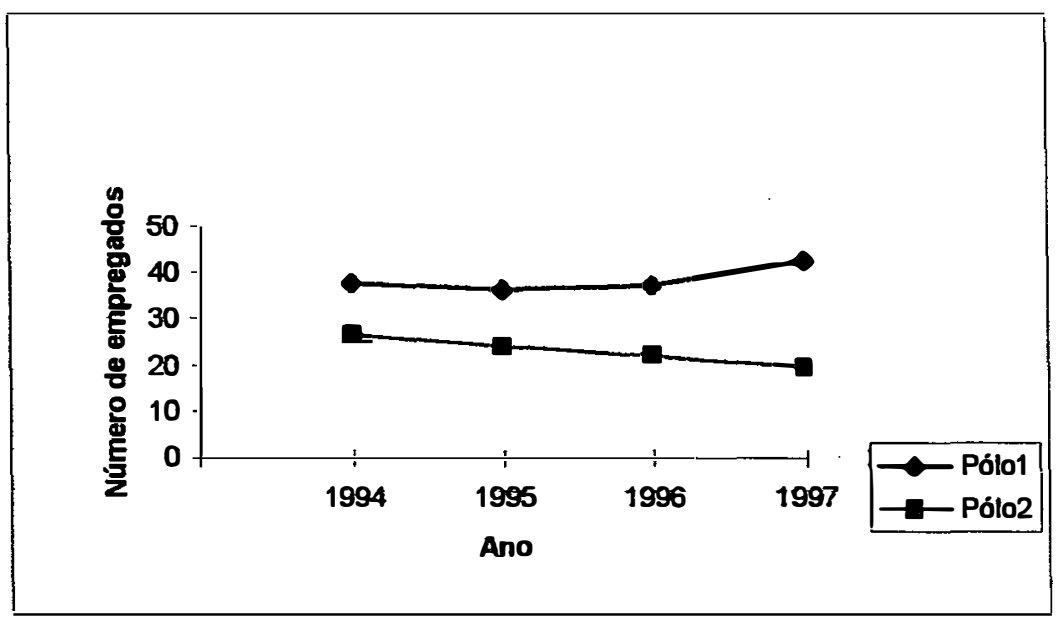

Figura 4- Evolução do número médio de empregados das empresas de processamento mecânico da madeira. 


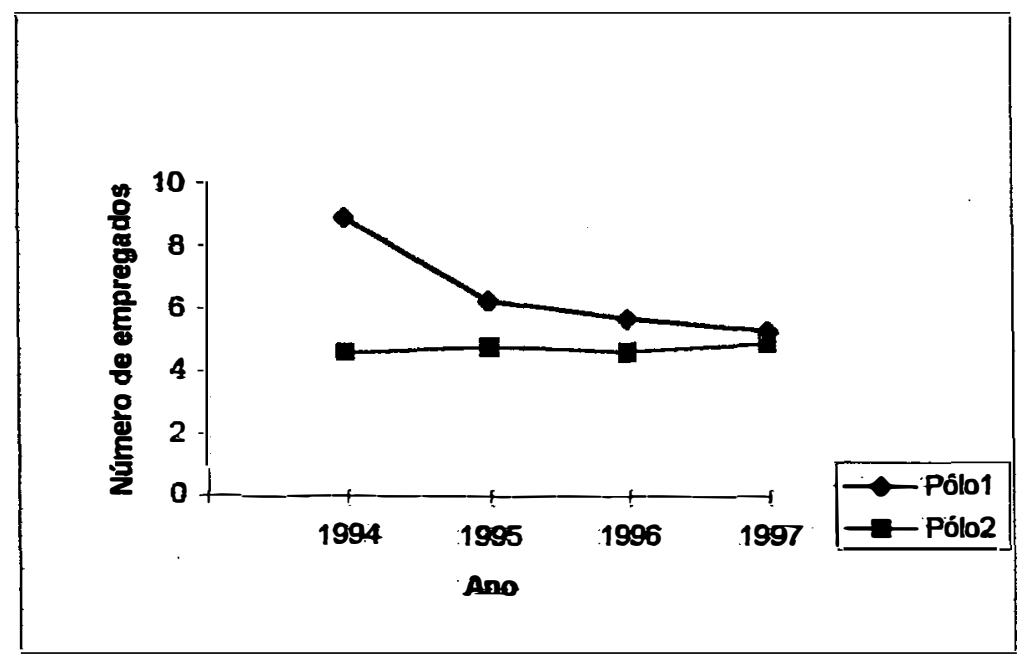

Figura 5- Evolução do número médio de empregados das empresas moveleiras

\subsection{Aspectos vinculados à migração dos proprietários das empresas.}

Na pesquisa verificou-se que, tanto no pólo 1 quanto no pólo 2 , há poucas empresas criadas na década de 70 , fato que pode estar associado, em parte, à migração dos proprietários para outras localidades.

Constatou-se que grande parte das empresas do setor industrial madeireiro foi criada na década de 90 , inclusive as localizadas no pólo 1 (55,1\% das empresas existentes). $\mathrm{O}$ que contribui para este resultado é o percentual de empresas moveleiras instaladas na década de 90 . Como já evidenciado antes, este tipo de empresa vem se ampliando no Estado, principalmente por haver grande aceitabilidade, por parte da população local, de móveis produzidos internamente e com madeiras de espécies "pouco conhecidas", que têm preço mais baixo.

Devido ao aumento no número de empresas moveleiras já está havendo 
dificuldade na obtenção de algumas espécies de madeiras "pouco conhecidas", como a garapeira e maracatiara, que foram citadas na pesquisa. Deve-se ressaltar, porém, que pelas respostas dos questionários, as espécies que se destacam como possuindo as maiores dificuldades na obtenção são as de maior valor comercial, como: o mogno, cerejeira e cedro.

No caso específico das empresas de processamento mecânico de madeira, presencia-se um maior percentual de empresas instaladas antes de 1990 no pólo 1 (61,9\% das empresas existentes) em relação ao pólo 2 (45,45\% das empresas existentes). No caso das empresas moveleiras, por serem relativamente recentes nas duas regiões, há um maior número de empresas criadas após 1989, porém, no pólo 2 este percentual é relativamente maior. Os resultados contidos na Tabela 16 comprovam mais uma vez a importância de se realizar a análise do setor industrial madeireiro do Estado de Rondônia por meio de dois pólos distintos, já que cada pólo guarda determinadas peculiaridades, como as que estão sendo identificadas no trabalho em questão.

Tabela 16- Distribuição percentual das empresas do setor industrial madeireiro de Rondônia segundo o ano de instalação

\begin{tabular}{c|c|c|c|c}
\hline & \multicolumn{2}{|c|}{ Pólo 1 } & \multicolumn{2}{c}{ Pólo 2 } \\
\hline Tipo de empresa & $\begin{array}{c}\text { Empresas } \\
\text { instaladas até } \\
1989\end{array}$ & $\begin{array}{c}\text { Empresas } \\
\text { instaladas na } \\
\text { década de } 90\end{array}$ & $\begin{array}{c}\text { Empresas } \\
\text { instaladas até } \\
1989\end{array}$ & $\begin{array}{c}\text { Empresas } \\
\text { instaladas na } \\
\text { década de } 90\end{array}$ \\
\hline $\begin{array}{c}\text { Processamento } \\
\text { mecânico da } \\
\text { madeira }\end{array}$ & 61,9 & 38,1 & 45,45 & 54,55 \\
\hline Moveleira & 32,14 & 67,86 & 29,27 & 70,73 \\
\hline Total & 44,9 & 55,1 & 36,49 & 63,51 \\
\hline
\end{tabular}

Fonte: dados da pesquisa de campo

Uma forma de verificar o processo de troca dos empresários é observando se a empresa já teve outros proprietários e se os proprietários já possuíram alguma 
empresa madeireira ou moveleira em outra localidade. Com o auxílio dos dados da Tabela 17, constata-se que, no total, as empresas pertencentes ao pólo 2 apresentaram um maior percentual em termos de mudança de proprietário, apesar de ser bastante próximo ao do pólo 1. No caso das empresas moveleiras, as que tiveram maiores mudanças foram as do pólo 1. Quanto às de processamento mecânico, o percentual foi maior para o pólo 2, com destaque para as empresas situadas no Município de Ariquemes.

Tabela 17- Percentagem de empresas que tiveram mais de um proprietário, proprietários que tiveram mais de uma empresa e empresa co-ligadas - setor industrial madeireiro de Rondônia, situação em 1997

\begin{tabular}{c|c|c|c|c|c|c}
\hline & \multicolumn{3}{|c|}{ Pólo 1 } & \multicolumn{3}{c}{ Pólo2 } \\
\hline $\begin{array}{c}\text { Tipo de } \\
\text { empresa }\end{array}$ & $\begin{array}{c}\text { Empresas } \\
\text { que tiveram } \\
\text { mais de um } \\
\text { proprietário } \\
\text { que tiveram } \\
\text { empresas em } \\
\text { outras } \\
\text { localidades }\end{array}$ & $\begin{array}{c}\text { Proprietários } \\
\text { compresas } \\
\text { ligadas }\end{array}$ & $\begin{array}{c}\text { Empresas } \\
\text { que tiveram } \\
\text { mais de um } \\
\text { proprietário }\end{array}$ & $\begin{array}{c}\text { Proprietários } \\
\text { que tiveram } \\
\text { empresas em } \\
\text { outras } \\
\text { localidades }\end{array}$ & $\begin{array}{c}\text { Empresas } \\
\text { co-ligadas }\end{array}$ \\
\hline $\begin{array}{c}\text { Processamento } \\
\text { mecânico da } \\
\text { madeira }\end{array}$ & 19,05 & 38,1 & 14,29 & 30,3 & 6,01 & 6,06 \\
\hline Moveleira & 17,86 & 0 & 0 & 11,9 & 4,76 & 0 \\
\hline Total & 18,37 & 16,33 & 6,12 & 20 & 5,33 & 2,67 \\
\hline
\end{tabular}

Fonte: dados da pesquisa de campo

Quanto à questão de o proprietário ter possuído outra empresa de processamento mecânico da madeira ou moveleira em outras localidades, constata-se que no pólo mais antigo (pólo 1) houve uma maior incidência, de cerca de 38,1\% para as empresas de processamento mecânico da madeira e $16,33 \%$ para o total.

Ao se analisar a questão de as empresas serem co-ligadas, observa-se que isto só ocorre com empresa de processamento mecânico da madeira e há maior predominância de respostas positivas no pólo 1, quando comparado ao pólo 2, podendo este aspecto estar associado ao fato daquelas empresas serem mais antigas. 
Dos resultados acima expostos, pode-se concluir que, até 1997, houve rotatividade significativa entre os empresários do setor industrial madeireiro de Rondônia, em especial no processamento mecânico da madeira. A troca de proprietário é um indicativo de que a questão de sustentabilidade não é um fator prioritário nas decisões dos empresários madeireiros instalados no Estado de Rondônia, pois muitos deles se empenham em manter a empresa quando há abundância de madeiras, vendendo a empresa e migrando para outra região quando as florestas se escasseiam.

\subsection{Escassez de espécies florestais}

Quando se está diante da escassez da principal matéria-prima, uma das alternativas adotadas pelas empresas é substituir a espécie escassa por outra com características relativamente semelhantes. Na década de oitenta, as serrarias usavam poucas espécies florestais ou somente uma, em decorrência de, basicamente, dois fatores: grande disponibilidade de certas espécies florestais e grande distância dos principais mercados consumidores de espécies madeireiras provenientes de Rondônia, o que, de certa forma, impedia a utilização de espécies que possuíam valores que não cobriam os custos de transporte.

Como já verificado na Tabela 14, atualmente, o maior atendimento ao mercado local possibilita a utilização de outras espécies florestais. Cerca de $70 \%$ das empresas localizadas no pólo 1 atendem ao mercado local e, aproximadamente, $67 \%$ das empresas do pólo 2 abastecem tal mercado.

As espécies mais utilizadas pelas empresas eram mogno e cerejeira. Com a escassez, estas foram sendo substituídas por outros tipos (maracatiara, angelim, ipê, jatobá, cumaru, samaúma, caxeta, caucho, entre outras). Na pesquisa de campo realizada, 
a média total de espécies utilizadas no pólo 1 permaneceu inalterada em 3 espécies, desde o ano de fundação da empresa, o mesmo ocorrendo no pólo 2. Mas, quando se observam apenas as empresas de processamento mecânico o valor médio de espécies usadas é maior que nas empresas moveleiras (ver Tabela 18). Outro ponto que deve ser salientado é o de que o número médio de espécies utilizadas continuou o mesmo, mas as espécies utilizadas pelas empresas foram sendo substituídas por outras, em decorrência especialmente da maior dificuldade de obtenção. Esperava-se na pesquisa que o número médio de espécies utilizadas pelas empresas do Estado de Rondônia fosse maior, fato que não vem ocorrendo, sendo este um aspecto preocupante, pois apesar de outras espécies já estarem sendo utilizadas o processo ainda é seletivo nas novas espécies. Ou seja, as espécies que predominam no uso pelas empresas do Estado acabam girando em torno de poucas.

Tabela 18- Número médio de espécies florestais utilizadas pelas empresas do setor industrial madeireiro do Estado de Rondônia

\begin{tabular}{c|c|c|c|c}
\hline & \multicolumn{2}{|c|}{ Pólo 1 } & \multicolumn{2}{c}{ Pólo 2 } \\
\hline Tipo de empresa & $\begin{array}{c}\text { Ano de } \\
\text { instalação da } \\
\text { empresa }\end{array}$ & Em 1997 & $\begin{array}{c}\text { Ano de instalação } \\
\text { da empresa }\end{array}$ & Em 1997 \\
\hline $\begin{array}{c}\text { Processamento } \\
\text { mecânico da } \\
\text { madeira }\end{array}$ & 4 & 4 & 4 & 4 \\
\hline Moveleira & 2 & 3 & 3 & 3 \\
\hline Total & 3 & 3 & 3 & 3 \\
\hline
\end{tabular}

Fonte: dados da pesquisa de campo

A tabela 19 confirma a utilização de outros tipos de madeira (por município), através da diminuição no uso das chamadas espécies de maior valor comercial (mogno e cerejeira), em decorrência da dificuldade na obtenção destas, pelas empresas de processamento mecânico de madeira. 
Tabela 19- Número de empresas de processamento mecânico de madeira em Rondônia que usavam e as que deixaram de utilizar as espécies florestais mogno e cerejeira - situação em 1997

\begin{tabular}{l|c|c|c|c}
\hline & $\begin{array}{c}\text { Número de } \\
\text { empresas que } \\
\text { comercializava } \\
\text { m a espécie } \\
\text { florestal mogno }\end{array}$ & $\begin{array}{c}\text { Número de } \\
\text { empresas que } \\
\text { deixaram de } \\
\text { comercializar a } \\
\text { espécie florestal } \\
\text { mogno }\end{array}$ & $\begin{array}{c}\text { Número de } \\
\text { empresas que } \\
\text { comercializava } \\
\text { m a espécie } \\
\text { florestal } \\
\text { cerejeira }\end{array}$ & $\begin{array}{c}\text { Número de } \\
\text { empresas que } \\
\text { deixaram de } \\
\text { comercializam a } \\
\text { espécie florestal } \\
\text { cerejeira }\end{array}$ \\
\hline Pólo 1 & 9 & 7 & 9 & 3 \\
\hline Vilhena & 3 & 3 & 3 & 0 \\
\hline Rolim de moura & 2 & 0 & 2 & 0 \\
\hline Pimenta Bueno & 2 & 2 & 2 & 1 \\
\hline Cacoal & 2 & 2 & 2 & 5 \\
\hline Pólo 2 & 4 & 4 & 10 & 1 \\
\hline Ariquemes & 2 & 2 & 5 & 0 \\
\hline Ji-Paraná & 1 & 1 & 3 & 2 \\
\hline Porto Velho & 1 & 1 & & \\
\hline Fonte: dados & & & & \\
\hline
\end{tabular}

Fonte: dados da pesquisa de campo

No que tange ao tipo de espécies madeireiras que têm dificuldades na obtenção, as mais citadas nos pólos 1 e 2 foram as espécies mogno e cerejeira. No primeiro pólo, nove empresas comercializavam a espécie mogno no ano de sua criação. Em 1997, sete deixaram de comercializar tal espécie (Tabela 19). No pólo 2, todas as empresas que usavam o mogno não o utilizam mais. No caso da cerejeira não se observou um abandono muito acentuado desta espécie. Também foram mencionadas, como tendo dificuldades de obtenção no pólo 1, as espécies peroba, angelim, cabriúva, garapeira, ipê, cumaru, cedro-rosa e cedro-marinheiro; e, no pólo 2, o freijó, ipê, cedro-rosa, angelim, maracatiara, cedro e sucupira. Há que destacar que a escassez do cedro, nos municípios de Ji-Paraná e Ariquemes, foi citada de forma considerável.

Quando se pergunta qual a atitude tomada pela empresa diante da dificuldade na obtenção de espécies florestais de valor comercial, no caso do pólo 1 houve grande incidência da resposta "substituição por outras espécies e mudança de ramo", com 
especial destaque para a produção de compensado. A freqüência de respostas também foi significativa nos itens "mudar para outro município" e "desativar a empresa". O quadro anteriormente mencionado se repete para o pólo 2, porém, há que ressaltar que as empresas pertencentes ao município de Ariquemes mencionaram com freqüência considerável a "adoção do reflorestamento".

O exposto acima denota a pouca preocupação do setor industrial madeireiro no Estado de Rondônia, em especial das empresa de processamento mecânico da madeira, com a sustentabilidade na continuidade das empresas e no uso de recursos florestais, evidenciando que os proprietários de empresas agem pensando mais no lucro obtido no curto prazo. Isto valida a hipótese formulada na introdução do presente trabalho.

\subsection{Eficácia dos órgãos ambientais em garantir a exploração florestal sustentável}

Incluí-se no questionários questões referentes à fiscalização e orientação das empresas pelos órgãos ambientais. As respostas estão na Tabela 20.

Quanto à fiscalização e orientação das empresas, deve-se ficar atento a algumas diferenças entre os pólos 1 e 2. As empresas de processamento mecânico da madeira no pólo 2 sofrem maior fiscalização (72,73\% do total de empresas), o que deve estar relacionado com a questão de estas empresas serem relativamente mais recentes e próximas de centros urbanos em que se localizam os órgãos florestais de fiscalização. No caso de as empresas só terem sido orientadas, verifica-se uma predominância também para as situadas no pólo 2, mas muito pequena. No pólo 1 , a incidência é nula para este último quesito. O pólo 1 possui maior número de empresas que foram fiscalizadas e orientadas simultaneamente.

As moveleiras só foram fiscalizadas, não sendo orientadas em nenhum dos 
dois pólos. O perfil das empresas moveleiras não se diferencia muito, em termos de fiscalização, do observado nas empresas de processamento mecânico da madeira, no que diz respeito ao pólo mais fiscalizado, que é o pólo 2 . Um ponto preocupante é a falta de orientação a estas empresas que vêm se expandindo no estado.

Tabela 20- Percentagem de empresas do setor industrial madeireiro de Rondônia que foram fiscalizadas e orientadas - situação em 1997

\begin{tabular}{c|c|c|c|c|c|c}
\hline & \multicolumn{3}{|c|}{ Pólo 1 } & \multicolumn{3}{c}{ Pólo 2 } \\
\hline $\begin{array}{c}\text { Tipo de } \\
\text { empresa }\end{array}$ & $\begin{array}{c}\text { Empresas } \\
\text { que só } \\
\text { foram } \\
\text { fiscalizada } \\
\mathrm{s}\end{array}$ & $\begin{array}{c}\text { Empresas } \\
\text { que só } \\
\text { foram } \\
\text { orientadas }\end{array}$ & $\begin{array}{c}\text { Empresas } \\
\text { que foram } \\
\text { fiscalizadas } \\
\text { e orientadas }\end{array}$ & $\begin{array}{c}\text { Empresas } \\
\text { que só } \\
\text { foram } \\
\text { fiscalizadas }\end{array}$ & $\begin{array}{c}\text { Empresas } \\
\text { que só } \\
\text { foram } \\
\text { orientadas }\end{array}$ & $\begin{array}{c}\text { Empresas que } \\
\text { foram } \\
\text { fiscalizadas e } \\
\text { orientadas }\end{array}$ \\
\hline $\begin{array}{c}\text { Processamento } \\
\text { mecânico da } \\
\text { madeira }\end{array}$ & 57,14 & 0 & 42,86 & 72,73 & 3,03 & 24,24 \\
\hline Moveleira & 75 & 0 & 0 & 80,95 & 0 & 0 \\
\hline Total & 67,35 & 0 & 18,37 & 77,33 & 1,33 & 10,67 \\
\hline
\end{tabular}

Fonte: dados da pesquisa de campo

No caso do manejo florestal, o percentual de empresas que enviou o plano ao IBAMA é maior no pólo 2 (ver Tabela 21). Enfatiza-se, porém, que estes percentuais são relativamente baixos nos dois pólos. Algumas empresas, para evitar a pressão para implantar o plano de manejo florestal e por orientação dos órgãos ambientais, arrendam uma área e contratam os serviços de uma outra empresa para elaborar o plano de manejo florestal a ser encaminhado ao IBAMA. Há conhecimento de cinco empresas que realizam este tipo de trabalho no estado, localizadas em Ariquemes, Porto Velho, Cacoal, Pimenta Bueno e Vilhena. Estas empresas são reconhecidas pelo IBAMA, que orienta as empresas industriais a procurarem estes serviços. Ressalta-se, porém, que é mais comum este procedimento para o caso de reflorestamento e que não há garantia de estas empresas estarem realmente utilizando os recursos para o reflorestamento. 
Tabela 21 - Percentagem de empresas do setor industrial madeireiro de Rondônia que têm plano de manejo enviado ao IBAMA - situação em 1997

\begin{tabular}{c|c|c}
\hline Tipo de empresa & Pólo 1 & Pólo 2 \\
\hline $\begin{array}{c}\text { Processamento } \\
\text { mecânico da } \\
\text { madeira }\end{array}$ & 28,03 & 39,39 \\
\hline Moveleira & 0 & 0 \\
\hline Total & 12,24 & 17,33 \\
\hline
\end{tabular}

Fonte: dados da pesquisa de campo

Um ponto que deve ser enfatizado diz respeito à questão de orientação às empresas madeireiras. Ficou visível na pesquisa de campo que os órgãos responsáveis pelas questões ambientais têm mais uma postura fiscalizatória, esquecendo-se que esta última ação não deve estar desvinculada do aspecto de orientação. Um ponto importante percebido na pesquisa é que uma parcela considerável de empresários não sabe o significado de reflorestamento e manejo florestal, confundindo estes dois termos. $\mathrm{O}$ fato foi percebido na pergunta quanto ao envio de plano de manejo ao IBAMA, onde diversas empresas responderam que haviam enviado o plano de manejo. O que se procede é que as empresas pagam uma taxa a outras empresas que realizam o reflorestamento. Com isso, as empresas madeireiras ficam cadastradas no IBAMA como cumpridoras das obrigações ambientais.

Portanto, a maior parte das empresas do Estado de Rondônia não tem preocupação com a questão da sustentabilidade. $\mathrm{O}$ interesse maior das empresas é estar regularizada no IBAMA ou SEDAM, não importando a forma, evitando, assim, a pressão destes órgãos. Outra comprovação da despreocupação com as questões de sustentabilidade e até por desconhecimento, por parte dos empresários, foi observada na pergunta sobre o incentivo do governo para o desenvolvimento sustentável, onde alguns empresários responderam que a forma de se obter seria "o governo não atrapalhar"; "diminuição dos impostos"; "incentivo às exportações"; "menor fiscalização do IBAMA"; 
"facilitar a retirada de madeira"; entre outras. Na maior parte das respostas, porém, seria por "meio da liberação de linhas de crédito e financiamento para o setor". Destaca-se que estas duas últimas respostas estão desvinculadas, na maior parte das vezes, da aplicação de tais recursos no manejo florestal e/ou reflorestamento

O mais provável é que a não implantação efetiva do plano de manejo esteja relacionada com o desconhecimento dos empresários sobre a sua vantagem e os impactos de redução na extração de madeira que implicam no curto prazo. No Apêndice B há a descrição de experiências de exploração florestal sustentável que ocorre na Amazônia e que não têm custos elevados. Experiências semelhantes podem ser adotadas com o auxílio do governo do estado, fornecendo linhas de créditos, e na atuação coletiva dos produtores auxiliados pelos órgãos ambientais que atuam no estado. 


\section{CONCLUSÃO}

O trabalho em questão analisou a evolução do setor industrial madeireiro do Estado de Rondônia, enfocando os aspectos de sustentabilidade da exploração florestal e o desempenho das empresas que compõem esse setor.

Com o intuito de atingir este objetivo, utilizou-se o arcabouço teórico da Economia Ecológica, com especial destaque para os conceitos de desenvolvimento sustentável e sustentabilidade. Constata-se que não existe um único conceito de desenvolvimento sustentável, e nem uma única forma de se atingir a sustentabilidade. No caso da Amazônia, três conceitos de desenvolvimento sustentável foram identificados, sendo o mais adequado para o setor industrial madeireiro de Rondônia a definição que enfatiza a utilização parcial da floresta.

Sobre a sustentabilidade do setor industrial madeireiro do Estado de Rondônia, conclui-se que, para que este setor possa sobreviver, é essencial a prática da reposição florestal, por meio do reflorestamento e/ou a implantação do manejo florestal por parte das empresas.

As políticas públicas adotadas na Amazônia e, mais especificamente, em Rondônia, tinham como metas primordiais o desenvolvimento da região e o estímulo à migração de pessoas localizadas em outras regiões do país para a Amazônia. As questões ambientais foram deixadas para segundo plano, fato que intensificou a implantação de um setor industrial madeireiro onde os empresários, estimulados pela facilidade de obtenção dos recursos florestais e pela falta de orientação e fiscalização por parte dos órgãos públicos, passaram a adotar um padrão de obtenção de tais recursos (florestais) através de mecanismos insustentáveis no longo prazo e extremamente seletivos, que causaram e continuam a causar a escassez de diversas espécies florestais, como o mogno, o cedro e a cerejeira. 
Portanto, esta visão imediatista dos empresários foi propiciada pelo fato de os órgãos públicos responsáveis pelas questões ambientais em Rondônia possuírem, até 1986, um discurso em que defendiam o desenvolvimento sustentável, mas, na realidade, as ações não eram, necessariamente, coerentes com esse tipo de desenvolvimento. A preocupação com o desenvolvimento sustentável ampliou-se nas políticas estaduais implantadas a partir da segunda metade da década de 80, mas não conseguiram, ainda, mudar a visão dos empresários.

$\mathrm{Na}$ pesquisa de campo realizada, observou-se que a visão da maioria dos empresários do setor madeireiro ainda é bastante restrita, preferindo alternativas que implicam soluções mais rápidas, quando se depara com a escassez de madeira, forçando a transferência da empresa para outras localidades (com o objetivo de ficar mais próxima da matéria-prima), a utilização de outras espécies florestais ou a desativação da empresa.

Quanto à preocupação de envio de plano manejo florestal ao IBAMA, este está praticamente restrito às empresas de processamento mecânico da madeira, apresentando uma maior percentual para as localizadas no pólo 2.

Foi constatado, também, que as ações dos órgãos públicos voltados às questões ambientais são mais dirigidas para o pólo 2, ressaltando que a fiscalização adotada pelos órgãos é em grande parte para se saber se as empresas possuem nota fiscal das espécies de madeiras compradas.

Da análise realizada, constata-se que a visão preponderante de curto prazo sobre o uso de recursos florestais deve ser alterada para uma visão mais abrangente sobre sustentabilidade. Necessário se torna uma política florestal estadual que estimule o manejo florestal e o reflorestamento. Além disso, as atividades de orientação não devem se limitar a apenas alguns municípios. É importante e fundamental recuperar a base florestal de todo o Estado.

Para a adoção dessa política são necessários recursos, medidas e 
providências que modifiquem a estrutura administrativa atual, com o intuito de diminuir a burocracia existente na adoção do plano de manejo. O tempo entre a entrega da proposta por parte das empresas até a sua aprovação é bastante extenso, o que, na maior parte das vezes, gera o desestímulo. 


\section{REFERÊNCIAS BIBLIOGRÁFICAS}

ALHO, C. Maneje com cuidado: Frágil. Ciência Hoje, Rio de Janeiro, volume especial (Amazônia), p. 100-107, dez. 1991.

ANUÁRIO ESTATÍSTICO BRASILEIRO. Rio de Janeiro, 1981-1997 (vários anos).

BACHA, C.J.C; SHIKIDA, P.F.A Experiências Brasileiras na Implantação do ICMS Ecológico. 1998. (mimeo).

BACHA, C.J.C; SHIKIDA, P.F.A. Experiências Brasileiras na Implantação do ICMS Ecológico. In: CASIMIRO FILHO, F.; SHIKIDA, P.F.A Agronegócio e Desenvolvimento Regional. Cascavel: EDUNIOESTE, 1999, p. 179-207 .

BARONI, M. Ambigüidades e Deficiências do Conceito de Desenvolvimento Sustentável. RAE, v 32, n-2 2, p. 14-24, 1992.

BARROS, A.C.; VERÍSSIMO, A ( org. ). A Expansão da Atividade Madeireira na Amazônia: Impactos e Perspectivas para o Desenvolvimento do Setor Florestal no Pará. Belém: IMAZON, 1996. 168 p.

BECKER, B.K. A Amazônia Pós ECO-92: Por um Desenvolvimento Regional Responsável. In: BURSZTYN, M. (org.) . Para Pensar o Desenvolvimento Sustentável. São Paulo: Editora Brasiliense, 1993.

BRASIL. INSTRUÇÃO NORMATIVA N $\mathrm{N}^{\circ}$ 001, de 05 de setembro de 1996. MINISTÉRIO DO MEIO AMBIENTE, DOS RECURSOS HÍDRICOS E DA AMAZÔNIA LEGAL. Seção 1, p.1. Dispõe sobre a Questão da Reposição 
Florestal.

BROWDER, J.O. ; MATRICARDI, E.A.T.; ABDALA, W.S. Is Sustainable Tropical Timber Production Financially Viable ? A Comparative Analysis of Mahogany Silviculture Among Small Famers in the Brazilian Amazon. Ecological Economics, n.16, p. 147-159, 1996.

BROWDER, J. O. Lumber Production and Economic Development in the Brazilian Amazon: Regional Trends and a Case Study. Journal of World Forest Resource Management, v. 4, n.1, p. 1-19, 1989.

BROWDER, J.O. Madeireiros na Mata Pluvial-Tropical: Uma Política Econômica de Extração Madeireira e Troca Desigual na Amazônia Brasileira. Tradução: Brent H. Millikan. Porto Velho-RO, dez. 1986. 24p

CARLTON,B. \& PERLOFF, J. Modern Industrial Organization. Harper Collins, 1991.

CATERPILLAR. Investindo no Capital da Natureza: Manejo Florestal Sustentável da Floresta, 1996.

CAVALCANTI, C. Breve Introdução à Economia da Sustentabilidade. In: CAVALCANTI, C. (org.). Desenvolvimento e Natureza: Estudos para uma Sociedade Sustentável. São Paulo: Cortez; Recife-PE: Fundação Joaquim Nabuco, 1995a. Cap 1, p. 17-25.

CAVALCANTI, C. (org.) . Desenvolvimento e Natureza: Estudos para uma Sociedade Sustentável. São Paulo: Cortez; Recife, PE: Fundação Joaquim Nabuco, 1995. 429 p.

CAVALCANTI, C. Sustentabilidade da Economia: Paradigmas Alternativos de 
Realização Econômica. In: CAVALCANTI, C. (org.). Desenvolvimento e Natureza: Estudos para uma Sociedade Sustentável. São Paulo: Cortez; Recife, PE: Fundação Joaquim Nabuco, 1995b. Cap 9, p. 153-174.

CIMA. Comissão Interministerial para preparação da Conferência das Nações Unidas sobre Meio Ambiente e Desenvolvimento. O desafio do Desenvolvimento Sustentável. Relatório do Brasil para a Conferência das Nações Unidas sobre Meio Ambiente e Desenvolvimento. Brasília, dezembro de 1991.

CORREA, C.M.; CORREA, A.A. A Madeira no Declínio do extrativismo Vegetal na Amazônia. In: CONGRESSO BRASILEIRO, 6, Campos do Jordão, 1990. Anais...Campos do Jordão : SBS/SBEF, 1990. v. 3. P. 1-4.

COSTA, J.M.M. da (org.). Amazônia: Desenvolvimento Econômico, Desenvolvimento Sustentável e Sustentabilidade de Recursos Naturais. Belém: UFPA. NUMA, 1995. (Universidade e Meio Ambiente n. 8). 204p.

COSTA, J.M.M. da. Desenvolvimento Regional e Desenvolvimento sustentável: Uma Avaliação de Consistência Macroeconômica. In: COSTA, J.M.M. da (org.). Amazônia: Desenvolvimento Econômico, Desenvolvimento Sustentável e Sustentabilidade de Recursos Naturais. Belém: UFPA. NUMA, 1995b. ( Universidade e Meio Ambiente n. 8). Cap. 1, p. 1-36.

COSTANZA, R. Economia Ecológica: Uma Agenda de Pesquisa. In: MAY, P.H; SERÔA DA MOTTA (org.). Valorando a Natureza: Análise Econômica para o Desenvolvimento Sustentável. Rio de Janeiro : Campus, 1994. Cap.7, P.111-144.

CURY, W. O Desenvolvimento Sustentável Decide o Futuro de Rondônia. Revista Setor Madeira, Ji-Paraná-Ro, jan. 1996. P.12-18. 
DIEGUES, A.( coord.). A Dinâmica Social do Desmatamento na Amazônia: Populações e Modos de Vida em Rondônia e Sudeste do Pará. São Paulo: UNRISD e NUPAUB- Universidade de São Paulo, 1993. 155p.

DOVERS, S.R. A Framework for Scaling and Framing Policy Problems in Sustainability. Ecological Economics, n. 12, p. 93-106, 1995.

ENCONTRO DE PESQUISADORES DA AMAZÔNIA. Zoneamento como Instrumento para o Desenvolvimento Sustentável na Amazônia. Porto VelhoRo, out. 1996. mimeo

FEARNSIDE, P.M. A Floresta Vai Acabar ?. Ciência Hoje, Rio de Janeiro, v. 2, n. 10, p. 43-52, jan/fev. 1984.

- Desmatamento e Desenvolvimento Agrícola na Amazônia. In : LÉNA, P.; OliVEIRA, A.E. de (org.). Amazônia. A Fronteira Agrícola 20 Anos Depois. Belém: CEJUP, Museu Paraense Emílio Goeldi, 1992. P. 207-222.

. Desmatamento na Amazônia Brasileira: Com que Intensidade Vem Ocorrendo?. Acta Amazonica, v. 12, p. 579-590, 1982.

FEARNSIDE, P.M. \& SALATI, E. Rondônia: Sem Florestas na Próxima Década ?. Ciência Hoje, Rio de Janeiro, v. 4, n. 19, p. 92-94. 1985.

FIERO. Federação das Indústrias do Estado de Rondônia. Perfil e Diretrizes de Desenvolvimento Industrial e de Infra-Estrutura. Porto Velho-RO, 1995. 471 p. 
FIERO. Federação das Indústrias do Estado de Rondônia. Perfil Socio-Econômico e Industrial. Porto Velho-RO, 1997. 332 p.

FREITAS, A.S. de; SOARES, P.R (org.). Aspectos Ambientais de projetos co-financiados pelo Banco Mundial: Lições para o Futuro. Brasília: IPEA, 1994. 156p.

FUNDAÇÃO INSTITUTO BRASILEIRO DE GEOGRAFIA E ESTATÍSTICA. Contagem da População. Resultados Relativos a Sexo da População e Situação da Unidade domiciliar. Rio de Janeiro: IBGE, v.1. 1996.

GODARD, O . A Gestão Integrada dos recursos Naturais e do Meio Ambiente: Conceitos, Instituições e Desafios de Legitimação. In: VIEIRA, P.F. \& WEBER, J. (org.). Gestão de Recursos Naturais Renováveis e Desenvolvimento: Novos Desafios para a pesquisa ambiental. São Paulo: Cortez, 1997. Cap. 5, p. 201 - 266.

GONÇALVES, A.C.R. Para não Repetir Rondônia. Ciência Hoje, Rio de Janeiro, v. 7, n. 40, mar. 1988.

HUMMEL, A.C; MINETTE, L.J. Aspectos do Setor Florestal do Estado do Amazonas. In: CONGRESSO BRASILEIRO , 6, Campos do Jordão, 1990. Anais...Campos do Jordão: SBS/SBEF, 1990. v. 3. P. 157-165.

IBAMA/FUNATURA. Diagnóstico e Avaliação do setor Florestal Brasileiro- Região Norte. Brasília, março 1996. (mimeo)

IBGE. Contagem da População. Resultados Relativos a Sexo da População e Situação da Unidade. v. 1.1996.

INPE/IBAMA. Desflorestamento 1995-1997. 1997 
ITERON. INSTITUTO DE TERRAS DE RONDÔNIA. RONDÔNIA: Desenvolver e Preservar. Porto Velho-RO, 1996. 31 p.

KITAMURA, P.C. A Amazônia e o Desenvolvimento Sustentável. Brasília: EMBRAPA-SPI, 1994. 182p.

. Políticas Ambientais para a Amazônia: Uma Avaliação Crítica.In:

COSTA, J.M.M. (org.). Amazônia: Desenvolvimento Econômico, Desenvolvimento Sustentável e Sustentabilidade de Recursos Naturais. Belém: UFPA. NUMA, 1995. ( Universidade e Meio Ambiente n. 8). Cap. 5, p. 125-162.

LEIS, H.R. \& D' AMATO, J.L. O Ambientalismo como Movimento Vital: Análise de suas Dimensões Histórica, Ética e Vivencial. In: CAVALCANTI, C. (org.). Desenvolvimento e Natureza: Estudos para uma Sociedade Sustentável. São Paulo: Cortez; Recife, PE: Fundação Joaquim Nabuco, 1995. Cap 5, p: 77-103.

LÉNA, P.; OliVEIRA, A.E. de (org.). Amazônia. A Fronteira Agrícola 20 Anos Depois. Belém: CEJUP, Museu Paraense Emílio Goeldi, 1992. 367p.

LEOPOLDO, P.R. \& SALATI, E. Rondônia: Quando a Floresta Vai Acabar ?. Ciência Hoje, Rio de Janeiro, v. 6, n. 35, p.14, 1987.

LISBOA, P.L.B. Alguns Aspectos do Impacto da colonização Humana sobre as Florestas de Rondônia. Boletim da Fundação Brasileira para a Conservação da Natureza, Rio de Janeiro, v. 24, p. 11-19, 1989.

Notas sobre a Atividade Industrial Madeireira e o Desmatamento na Amazônia Brasileira. Boletim da Fundação Brasileira para a Conservação da 
Natureza, Rio de Janeiro, p. 72-85, 1986.

LISBOA, P.L.B.; MACIAL, U.N..; PRANCE, G.T. Perdendo Rondônia. Ciência Hoje, Rio de Janeiro, volume especial (Amazônia), p. 74- 82, dez. 1991.

LISBOA, P.L.B. Rondônia: Colonização e Floresta. Brasília: SCT/PR-CNPq , 1990. 212 p. (Programa Polonoroeste: relatório de Pesquisa ${ }^{\circ}{ }^{9}$ ).

LOREIRO, ICMS Ecológico - Uma Experiência Brasileira Exitosa no Incentivo Econômico para a Conservação da Biodiversidade. Caderno de Biodiversidade, Curitiba, volume 1, n. 2, p. 25-47, dez. 1998.

MAHAR, D. As Políticas Governamentais e o Desmatamento na Região Amazônica do Brasil. In: BOLOGNA, G (org ). Amazônia Adeus. Tradução: Raffaella De Filippis. Rio de Janeiro: Editora Nova Fronteira., 1990. 288p.

MATRICARDI, E.A.T; ABDALA, W.S. Mogno em Rondônia. Porto Velho-RO: SEBRAE, 1994. 62p.

MATRICARDI, E.A.T. Uso e Ocupação das Terras Rurais em Rondônia. Secretaria de Estado do Desenvolvimento Ambiental- SEDAM, Porto Velho-RO, 1996. 23 p.

MAY, P.H (org.). Economia Ecológica: Aplicações para o Brasil. Rio de Janeiro: Campus, 1995. 179p.

MAY, P.H. Economia Ecológica e o Desenvolvimento Eqüitativo no Brasil. In: MAY, P.H (org.). Economia Ecológica: Aplicações no Brasil. Rio de Janeiro: Campus, 1995. Cap. 1, p. 1-20.

MENDES. A.D. Envolvimento e Desenvolvimento: Introdução à Simpatia de todas as 
Coisas. In: CAVALCANTI, C. (org.). Desenvolvimento e Natureza: Estudos para uma Sociedade Sụstentável. São Paulo: Cortez; Recife, PE: Fundação Joaquim Nabuco, 1995b. Cap 4, p. 54 - 76.

NEDER, R.T. Problemas de Regulação Pública e Planejamento Governamental Envolvidos no Debate sobre sustentabilidade, Planejamento e Políticas Públicas, n. 11, jan/dez de 1994.

OPSCHOOR, H; STRAATEN, J.V.D. Sustainable Development: An Institutional Approach. Ecological Economics, n.7, p. 203-222, 1993.

PANDOLFO, C. A Questão Florestal na Amazônia. In: COSTA, J.M.M. (org.) . Amazônia: Desenvolvimento Econômico, Desenvolvimento Sustentável e Sustentabilidade de Recursos Naturais. Belém: UFPA. NUMA, 1995. (Universidade e Meio Ambiente n. 8). Cap. 4, p. 105-124.

PINTO, L.F. Pará: O Desenho de um Novo Perfil. In: COSTA, J.M.M., org. Amazônia: Desenvolvimento Econômico, Desenvolvimento Sustentável e Sustentabilidade de Recursos Naturais. Belém: UFPA. NUMA, 1995. (Universidade e Meio Ambiente n. 8). Cap. 6, p. 163-190.

RIBAS, O. R. Diagnóstico Setorial do Meio Ambiente e Recursos Naturais. PNUD, Brasília, dezembro de 1997. (mimeo).

SCHUBART, H. Planejando a Ocupação Sustentável do Território Nacional: O Exemplo da Amazônia. Planejamento e Políticas Públicas, n. 7, Junho de 1992.

SEPLAN-RO. Secretaria de Planejamento do Estado de Rondônia. PLANAFLORO. Porto Velho, 1990. (mimeo) 
SECRETARIA ESPECIAL DO MEIO AMBIENTE. Diretrizes Ambientais para Rondônia; Documento Compacto. Brasília, 1986. 223p.

SEDAM. SECRETARIA DE ESTADO DO DESENVOLVIMENTO AMBIENTAL Desmatamento em Rondônia. Porto Velho-RO, 1996. 48p

SEDAM. SECRETARIA DE ESTADO DO DESENVOLVIMENTO AMBIENTAL Desmatamento em Rondônia. Porto Velho-RO, 1997.

SEKIGUCHI, C. \& PIRES, E.L.S. Agenda para uma Economia Política da Sustentabilidade: potencialidades e Limites para o seu Desenvolvimento no Brasil. In: CAVALCANTI, C. (org). Desenvolvimento e Natureza: Estudos para uma Sociedade Sustentável. São Paulo: Cortez; Recife, PE: Fundação Joaquim Nabuco, 1995. Cap. 12, p: 208-234.

SEMAM/IBAMA. Programa Nacional de Conservação e Desenvolvimento Florestal Sustentado. Brasília, 1991.

SEPLAN-RO. SECRETARIA DE ESTADO DO PLANEJAMENTO E COORDENAÇÃO GERAL DE RONDÔNIA. Perfil Econômico do Estado de Rondônia. Porto Velho-RO. 86p.

SERRÃO. Desenvolvimento Agropecuário e Florestal na Amazônia: Proposta para o Desenvolvimento Sustentável com Base no Conhecimento Científico e Tecnológico. In: COSTA, J.M.M (org.). Amazônia: Desenvolvimento Econômico, Desenvolvimento Sustentável e Sustentabilidade de Recursos Naturais. Belém: UFPA. NUMA, 1995. (Universidade e Meio Ambiente n. 8). Cap. 3, p. 57-104. 
SILVA, J.N.M. \& ULH, C. A Atividade Madeireira como uma Alternativa Viável para a Utilização Sustentada dos Recursos Florestais na Amazônia Brasileira. In: HOYOS, J.L.B. Desenvolvimento sustentável : Um Novo Caminho ?. Belém: UFPA. NUMA, 1992. (Universidade e Meio Ambiente n. 3). p. 95-106

SIQUEIRA, J.D.; SOUZA, M.F. de . Os sistemas de Manejo Florestal na Amazônia. In: CONGRESSO BRASILEIRO , 6, Campos do Jordão, 1990. Anais...Campos do Jordão: SBS/SBEF, 1990. v. 2. P. 78-84.

STAHEL, A.W. Capitalismo e Entropia: Os Aspectos Ideológicos de uma Contradição e a Busca de Alternativas Sustentáveis. In: CAVALCANTI, C. (org.). Desenvolvimento e Natureza: Estudos para uma Sociedade Sustentável. São Paulo: Cortez; Recife, PE: Fundação Joaquim Nabuco, 1995. Cap. 6, p. 104-127.

SUDAM. Ação Governamental na Amazônia: Subsídios ao Zoneamento EcológicoEconômico e ao Plano de Desenvolvimento da Amazônia. Dezembro de 1990. (mimeo),

SUDAM. Simpósio Internacional sobre Cenários de Desenvolvimento Sustentável na Amazônia: Alternativas Econômicas e Perspectivas de Cooperação Internacional. Belém, mar. 1992.62p.

TEREZO, E.F.M. As indústrias na Amazônia e o uso dos recursos florestais . In: CONGRESSO BRASILEIRO , 6, Campos do Jordão, 1990. Anais...Campos do Jordão: SBS/SBEF, agosto de 1997.1990. v. 1. P. 19-24.

TOLMASQUIM, M.T. Economia do Meio Ambiente: Forças e Fraquezas. In: CAVALCANTI, C. (org.). Desenvolvimento e Natureza: Estudos para uma Sociedade Sustentável. São Paulo: Cortez; Recife, PE: Fundação Joaquim Nabuco, 
1995. Cap. 17, p: 323-341.

TOMPKIN, J. R. Estatística e Métodos de Pesquisa em Ciências Sociais Rurais. Piracicaba: ESALQ, agosto de 1967.

UFRRJ/ IBDF. Contribuição do Mercado Madeireiro no Desenvolvimento Regional Rondônia. Rio de Janeiro, 1988. 425p.

UFRRJ/IBDF. Diagnóstico da Indústria Madeireira do Estado de Rondônia. Rio de Janeiro, 1983. 146p.

UHL, C. \& BUSCHBACHER, R. Queimada: O Corte que Atrai. Ciência Hoje, Rio de Janeiro, volume especial (Amazônia), p. 84-88, dez. 1991.

UHL, C. \& VIEIRA, I.C.G. Seleção Predatória. Ciência Hoje, Rio de Janeiro, volume especial (Amazônia), p. 108-115, dez. 1991.

UHL, C.; BARRETO, P.; VERÍSSIMO, A. ; BARROS, A.C.; AMARAL,P; VIDAL, E; JUNIOR, C. S. Uma Abordagem Integrada de Pesquisa sobre o Manejo dos Recursos Naturais na Amazônia. In: BARROS, A.C. ; VERÍSSIMO, A. A Expansão da Atividade Madeireira na Amazônia: Impactos e Perspectivas para o Desenvolvimento do Setor Florestal no Pará. Belém: IMAZON, 1996b. Cap 5, p.141-164.

VERÍSSIMO, A; BARRETO, p.; MATOS, M.; TARIFA, R.; UHL, C. Impactos da Atividade madeireira e Perspectiva para o Manejo Sustentável da Floresta numa Velha Fronteira da Amazônia: O Caso de Paragominas. In: BARROS, A.C. ; VERÍSSIMO, A. A Expansão da Atividade Madeireira na Amazônia: Impactos e Perspectivas para o Desenvolvimento do Setor Florestal no Pará. Belém: 
IMAZON, 1996b. Cap 2, p.45 74

VERÍSSIMO, A; UHL, C.; MATOS, M.; BRADINO, Z.; VIEIRA. Impactos Sociais, Econômicos e Ecológicos da Exploração Seletiva de Madeiras numa Região de Fronteira na Amazônia Oriental: O Caso da Tailândia. In: BARROS, A.C. ; VERÍSSIMO, A. A Expansão da Atividade Madeireira na Amazônia: Impactos e Perspectivas para o Desenvolvimento do Setor Florestal no Pará. Belém: IMAZON, 1996a. Cap 1, p. 7-44

YARED, J.A.G.; JUNIOR, S.B. A Atividade Florestal e o Desenvolvimento Florestal na Amazônia. Pará Desenvolvimento, Belém, n. 25, p. 60-64, Jan/dez. 1989. 
APÊNDICES A e B 


\section{APÊNDICE A - QUESTIONÁRIO SOBRE O SETOR INDUSTRIAL MADEIREIRO DO ESTADO DE RONDÔNIA}

\section{1- Características Gerais}

1.1-Município onde se localiza a empresa?

1.2- Qual o ano de instalação da empresa? . Sua empresa é associada a outra empresa madeireira (sim ou não)? . Em caso de resposta afirmativa, quando surgiu a outra empresa e em que Estado opera?

1.3- A empresa já teve outros proprietários (sim ou não)? . Em caso afirmativo, especificar, se possível, quantos foram os proprietários anteriores:

1.4- O proprietário já possuiu alguma empresa madeireira em outra localidade (sim ou não)? . Em caso afirmativo, especificar o local da outra empresa e, se possível, os motivos que o levaram a transferir-se para 0 atual munícipio: 
1.5- Qual foi a quantidade média de empregados nos últimos quatro anos?

\begin{tabular}{|l|c|c|c|}
\hline 1994 & 1995 & 1996 & 1997 \\
\hline $\begin{array}{l}\text { Número de } \\
\text { empregados }\end{array}$ & & & \\
\hline
\end{tabular}

1.6- Quantos empregados permanentes trabalham na empresa atualmente?

1.7- Quantos empregados temporários trabalham na empresa atualmente?

1.8- Quais são os tipos de mercados atendidos pela empresa? (marcar com X, sendo válida mais de uma resposta).

\begin{tabular}{|c|c|c|c|c|}
\hline Local & Estadual & $\begin{array}{c}\text { Região } \\
\text { Amazônica }\end{array}$ & $\begin{array}{c}\text { Outras Regiões } \\
\text { do Brasil }\end{array}$ & Outros Países \\
\hline & & & & \\
\hline
\end{tabular}

\section{2- Produção}

2.1- Preencha o quadro abaixo sobre a capacidade de produção mensal de sua empresa para os produtos listados (considerar o ano de 1997): 


\begin{tabular}{|l|l|l|}
\hline \multicolumn{1}{|c|}{ Produtos } & Unidade & $\begin{array}{c}\text { Capacidade de produção } \\
\text { (quantidade) mensal }\end{array}$ \\
\hline Madeira serrada & & \\
\hline Laminado & & \\
\hline Compensado & & . \\
\hline Móveis & & \\
\hline Outros especificar & & \\
\hline & & \\
\hline & & \\
\hline
\end{tabular}


2.2.1- Qual foi o volume total de produção para os últimos 4 anos (especificar por produto). Caso não seja possível para os quatro anos, colocar para 1996 e 1997.

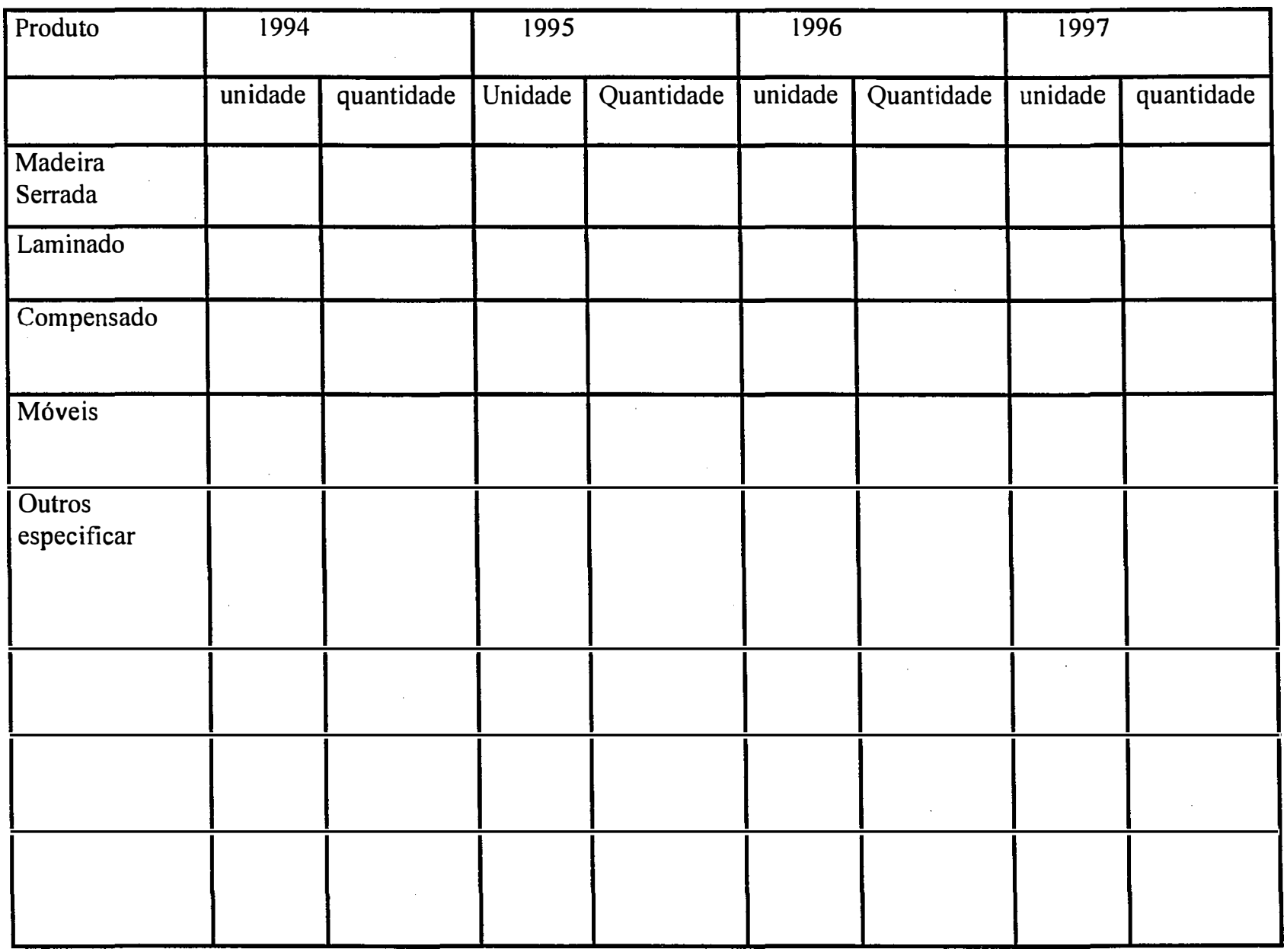


2.2.2 - Sua empresa deseja diversificar a produção (sim ou não)? . Em caso afirmativo, qual será o novo produto?

2.3- Citar as principais espécies de madeira que eram utilizadas pela empresa no ano em que foi criada e as que são usadas atualmente na produção (colocar em ordem decrescente de importância)

\begin{tabular}{|c|c|c|}
\hline & $\begin{array}{l}\text { Ano de início da } \\
\text { empresa }\end{array}$ & 1997 \\
\hline & \multicolumn{2}{|c|}{ Espécies } \\
\hline 1 & & \\
\hline 2 & & \\
\hline 3 & & \\
\hline 4 & & \\
\hline 5 & & \\
\hline 6 & & \\
\hline 7 & & \\
\hline 8 & & \\
\hline 9 & & \\
\hline 10 & & \\
\hline 11 & & \\
\hline 12 & & \\
\hline 13 & & \\
\hline 14 & & \\
\hline 15 & & \\
\hline 16 & & \\
\hline 17 & & \\
\hline
\end{tabular}




\begin{tabular}{|l|l|l|}
\hline 18 & & \\
\hline 19 & & \\
\hline 20 & & \\
\hline 21 & & \\
\hline 22 & & \\
\hline 23 & & \\
\hline 24 & & \\
\hline 25 & & \\
\hline 26 & & \\
\hline 27 & & \\
\hline 28 & & \\
\hline 29 & & \\
\hline 30 & & \\
\hline 31 & & \\
\hline
\end{tabular}


2.4- Quais são os principais problemas da empresa na área de produção?

2.5- Há planos futuros de ampliação da empresa (sim ou não)? .Em caso afirmativo, $\quad$ especificar suais os planos?

\section{3- Matéria - Prima}

3.1 - A sua empresa tem floresta própria em Rondônia (sim ou não)? . Em caso afirmativo, especificar a área própria com matas nativas e plantadas: hectares com matas nativas e hectares com matas plantadas

3.2- Do total de madeira utilizada, quanto é oriundo das seguintes fontes (colocar no espaço em branco o percentual do volume total obtido de cada fonte)? 


\begin{tabular}{|c|c|c|c|c|c|c|}
\hline Ano & $\begin{array}{c}\text { Terra } \\
\text { própria }\end{array}$ & $\begin{array}{l}\text { Terras de } \\
\text { terceiros }\end{array}$ & $\begin{array}{l}\text { Floresta na- } \\
\text { cional, esta- } \\
\text { dual e reser- } \\
\quad \text { vas }\end{array}$ & $\begin{array}{c}\text { Terras devo- } \\
\text { lutas }\end{array}$ & Não sei & Total \\
\hline $\begin{array}{l}\text { Ano de iní- } \\
\text { cio da } \\
\text { empresa }\end{array}$ & $\%$ & $\%$ & $\%$ & $\%$ & $\%$ & $100 \%$ \\
\hline 1997 & $\%$ & $\%$ & $\%$ & $\%$ & $\%$ & $100 \%$ \\
\hline
\end{tabular}

3.3- Qual é a distância mínima, média e máxima que a empresa adquiria a madeira no ano em que foi criada e estas mesmas distâncias para o ano de 1997.

\begin{tabular}{|l|c|c|}
\hline & Ano de criação da empresa & 1997 \\
\hline Mínima & $\mathrm{Km}$ & $\mathrm{km}$ \\
\hline Média & $\mathrm{Km}$ & $\mathrm{km}$ \\
\hline Máxima & $\mathrm{Km}$ & $\mathrm{km}$ \\
\hline
\end{tabular}

3.4- Há dificuldade na obtenção de alguma espécie de madeira (sim ou não)?______ Em caso afirmativo, citar as espécies em que há dificuldade de obtenção? 


\section{4- Fiscalização do IBAMA}

4.1 - O IBAMA ou a SEDAM vem orientado a empresa sobre a necessidade de um plano de reflorestamento e/ou manejo florestal (sim ou não)? - Em caso afirmativo, descrever como está sendo realizada esta orientação?

4.2- Quantas vezes no ano a sua empresa é fiscalizada pelo IBAMA?

4.3- A forma de fiscalização utilizada pelo IBAMA dificulta a obtenção de madeira (sim ou não)?

\section{5- Estratégias para o caso de falta de madeira}

5.1- A empresa possui algum plano de manejo florestal já encaminhado ao IBAMA (sim ou não)?_._. Se a resposta for negativa, quais são os motivos?

Caso a resposta seja afirmativa, o plano de manejo já foi aprovado pelo IBAMA (sim ou não)?______ Em caso afirmativo, o plano de manejo já está sendo adotado (sim ou não)?

5.2- Se houver bastante dificuldade em se obter madeira, principalmente mogno, cedro e 
cerejeira, qual é a atitude a ser tomada pela empresa (marcar com $\mathrm{x}$ ).

\begin{tabular}{|l|l|}
\hline & "X" \\
\hline Adotar um plano de manejo florestal & \\
\hline Implantar o reflorestamento & \\
\hline Mudar para outro município ou estado & \\
\hline Desativar a empresa & \\
\hline Outros (especificar) & \\
\hline & \\
\hline
\end{tabular}

5.3- Que tipo de incentivo o governo poderia proporcionar para o desenvolvimento sustentável do Setor Industrial madeireiro? 


\section{APÊNDICE B - EXPERIÊNCIAS DE EXPLORAÇÃO FLORESTAL SUSTENTÁVEL NO BRASIL}

Os prejuízos causados por uma extração que não leva em conta um planejamento da retirada de espécies florestais ficam claros na pesquisa realizada pelo Instituto do Homem e do Meio Ambiente, IMAZON (CATERPILLAR, 1996). Neste trabalho, realizou-se uma comparação entre o tipo de extração convencional (sem um estudo prévio da região de retirada de espécies florestais) e a extração de baixo impacto, com a utilização de trator florestal, tomando a situação existente em Paragominas. Os resultados evidenciam a necessidade urgente da exploração sustentável da floresta. No primeiro tipo de extração, cerca de 235 árvores/ha são danificadas, enquanto pouco mais da metade deste valor (aproximadamente 132 árvores/ha) sofrem algum tipo de danos na forma de baixo impacto.

Outro fator relevante demostrado na pesquisa é o prazo para novas retiradas de madeiras das regiões exploradas. Na convencional. o prazo varia de 70 a 100 anos, sendo reduzido para 30 a 40 anos na de baixo impacto. Nesta última, toda a madeira que é derrubada é de alguma maneira aproveitada, fato não verificado no outro tipo de extração, que descarta aproximadamente $7 \mathrm{~m}^{3} /$ ha de madeiras - que poderiam ser vendidas - em decorrência da ineficiência na forma de extração.

Constatou-se, também no estudo, que na extração convencional, aproximadamente, $10,4 \mathrm{~m}^{3}$ de madeiras que poderiam ser vendidas são danificadas ou destruídas. Este valor cai para $5,7 \mathrm{~m}^{3}$ na extração de baixo impacto.

Quanto aos custos, este é menor para a convencional por não haver gastos que são necessários no processo de extração de baixo impacto, destacando-se os dispêndios, desta última, nas seguintes etapas: planejamento, corte de cipós, derrubada direcional, abertura de trilhos de tratores florestais, estradas ou plataformas de toras. Os castos da extração de baixo impacto, porém, podem ser compensados por um aumento na 
eficiência de extração, que depende da intensidade de extração e por meio da utilização de trator florestal, que reduz o desperdício de madeiras.

$\mathrm{Na}$ extração de baixo impacto faz-se, primeiramente, um inventário da área onde se pretende retirar as espécies de madeira. Além de observar quais são as espécies potencialmente comercializáveis, possuindo um diâmetro acima de $35 \mathrm{~cm}$. Também são verificadas as quantidades de mudas e árvores novas, com o intuito de serem colhidas no futuro. Por meio do inventário, elaboraram-se três tipos de mapas. O primeiro, define todas as árvores que estão localizadas na área escolhida para a retirada das árvores; o segundo, indica, apenas, as árvores que devem ser cortadas; e, o terceiro, mostra, os caminhos para as operações de transporte a serem realizadas com o trator florestal. Estes três mapas auxiliam o processo de derrubada e transporte das espécies florestais.

Após a seqüência acima descrita, há necessidade do corte de todos os cipós, que podem prejudicar outras espécies na retirada das árvores escolhidas. No passo seguinte, as árvores selecionadas são marcadas, verificando-se, também, em que direção estas devem ser derrubadas, evitando, com isso, danificar outras espécies florestais. Os caminhos que devem ser percorridos são marcados, auxiliando o operador a encontrar as espécies selecionadas. Estradas, também, são construídas, porém, estas devem ser bastante estreitas e em menor número possível.

Após o corte da árvore, deve-se ter o cuidado de movê-la com o trator florestal, com o objetivo de causar o mínimo de dano no processo de extração. $\mathrm{O}$ trator fica a uma distância de 5 a 10 metros da tora a ser derrubada, para que na etapa de retirada da floresta a mesina permaneça acima do chão, não causando buracos no solo. 